\title{
Spatial Distribution of Miocene Foraminifera at Calvert Cliffs, Maryland
}

MARTIN A. BUZAS and THOMAS G. GIBSON

SMITHSONIAN CONTRIBUTIONS TO PALEOBIOLOGY - NUMBER 68 


\title{
SERIES PUBLICATIONS OF THE SMITHSONIAN INSTITUTION
}

Emphasis upon publication as a means of "diffusing knowledge" was expressed by the first Secretary of the Smithsonian. In his formal plan for the Institution, Joseph Henry outlined a program that included the following statement: "It is proposed to publish a series of reports, giving an account of the new discoveries in science, and of the changes made from year to year in all branches of knowledge." This theme of basic research has been adhered to through the years by thousands of titles issued in series publications under the Smithsonian imprint, commencing with Smithsonian Contributions to Knowledge in 1848 and continuing with the following active series:

\author{
Smithsonian Contributions to Anthropology \\ Smithsonian Contributions to Astrophysics \\ Smithsonian Contributions to Botany \\ Smithsonian Contributions to the Earth Sciences \\ Smithsonian Contributions to the Marine Sciences \\ Smithsonian Contributions to Paleobiology \\ Smithsonian Contributions to Zoology \\ Smithsonian Folklife Studies \\ Smithsonian Studies in Air and Space \\ Smithsonian Studies in History and Technology
}

In these series, the Institution publishes small papers and full-scale monographs that report the research and collections of its various museums and bureaux or of professional colleagues in the world of science and scholarship. The publications are distributed by mailing lists to libraries, universities, and similar institutions throughout the world.

Papers or monographs submitted for series publication are received by the Smithsonian Institution Press. subject to its own review for format and style, only through departments of the various Smithsonian museums or bureaux, where the manuscripts are given substantive review. Press requirements for manuscript and art preparation are outlined on the inside back cover.

Robert McC. Adams Secretary

Smithsonian Institution 
SMITHSONIAN CONTRIBUTIONS TO PALEOBIOLOGY $•$ NUMBER 68

\section{Spatial Distribution of Miocene Foraminifera at Calvert Cliffs, Maryland}

Martin A. Buzas and Thomas G. Gibson

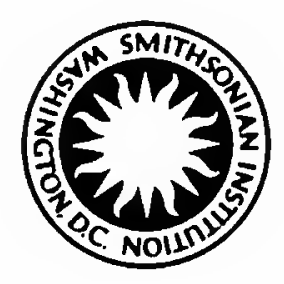

SMITHSONIAN INSTITUTION PRESS

Washington, D.C. 1990 


\section{A B S T R A C T}

Buzas, Martin A., and Thomas G. Gibson. Spatial Distribution of Miocene Foraminifera at Calvert Cliffs, Maryland. Smithsonian Contributions to Paleobiology, number 68, 35 pages, frontispiece, 4 figures, 14 tables, 1990.-Excavations made in middle Miocene strata in the Calvert Cliffs of Maryland during construction of a nuclear power plant were used for a spatial distribution study of fossil benthic foraminifera over large bedding surfaces. Two bedding surfaces were sampled, a larger and older one involving a $400 \mathrm{~m}^{2}$ surface in the Calvert Formation, and a slightly younger one involving a $50 \mathrm{~m}^{2}$ surface in the Choptank Formation. The sampling procedure for both surfaces consisted of a 3- $\times 3$-station grid, with 5 replicates taken at each of 9 stations. The larger surface had stations at $9.5 \mathrm{~m}$ centers, and the smaller surface had stations at $3.6 \mathrm{~m}$ centers.

The amount of variation in species proportions and densities from each bedding surface were used to determine how much confidence can be placed in the results from the usual paleontologic sampling procedure of a single sample.

Unispecies and multispecies analyses were done on the 45 samples from each of the surfaces. The study of the older surface involved 36 species, and the younger 33 . Analyses indicate a remarkable degree of homogeneity of species densities and proportions in both of these beds. Species usually remain in the same rank order at all stations within each surface, indicating that any of the 45 samples gives a reasonable species composition for the surface. Species densities exhibit greater variability; the determination of confidence limits for species densities requires multiple samples to reach limits of \pm 50 percent accuracy.

OfFICIAL PUBLICATION DATE is handstamped in a limited number of initial copies and is recorded in the Institution's annual report, Smithsonian Year. SERIES COVER DESIGN: The trilobite Phacops rana Green.

Library of Congress Cataloging in Publication Data

Buzas, Martin A.

Spatial distribution of Miocene Foraminifera at Calvent Cliffs, Maryland / Martin A. Buzas and Thomas G. Gibson.

p. cm.- (Smithsonian contributions to paleobiology ; no. 68)

Includes bibliographical references.

1. Foraminifera, Fossil-Maryland-Calven Cliffs. 2. Paleontology-Miocene. 3. Paleontology-MarylandCalvert Cliffs. I. Gibson, Thomas G. II. Title. III. Series.

QE701.S56 no.68 $[\mathrm{QE} 772] \quad 560 \mathrm{~s}-\mathrm{dc20} \quad\left[563^{\prime} .12^{\prime} 0975244\right] \quad 89-600314$ 


\section{Contents}

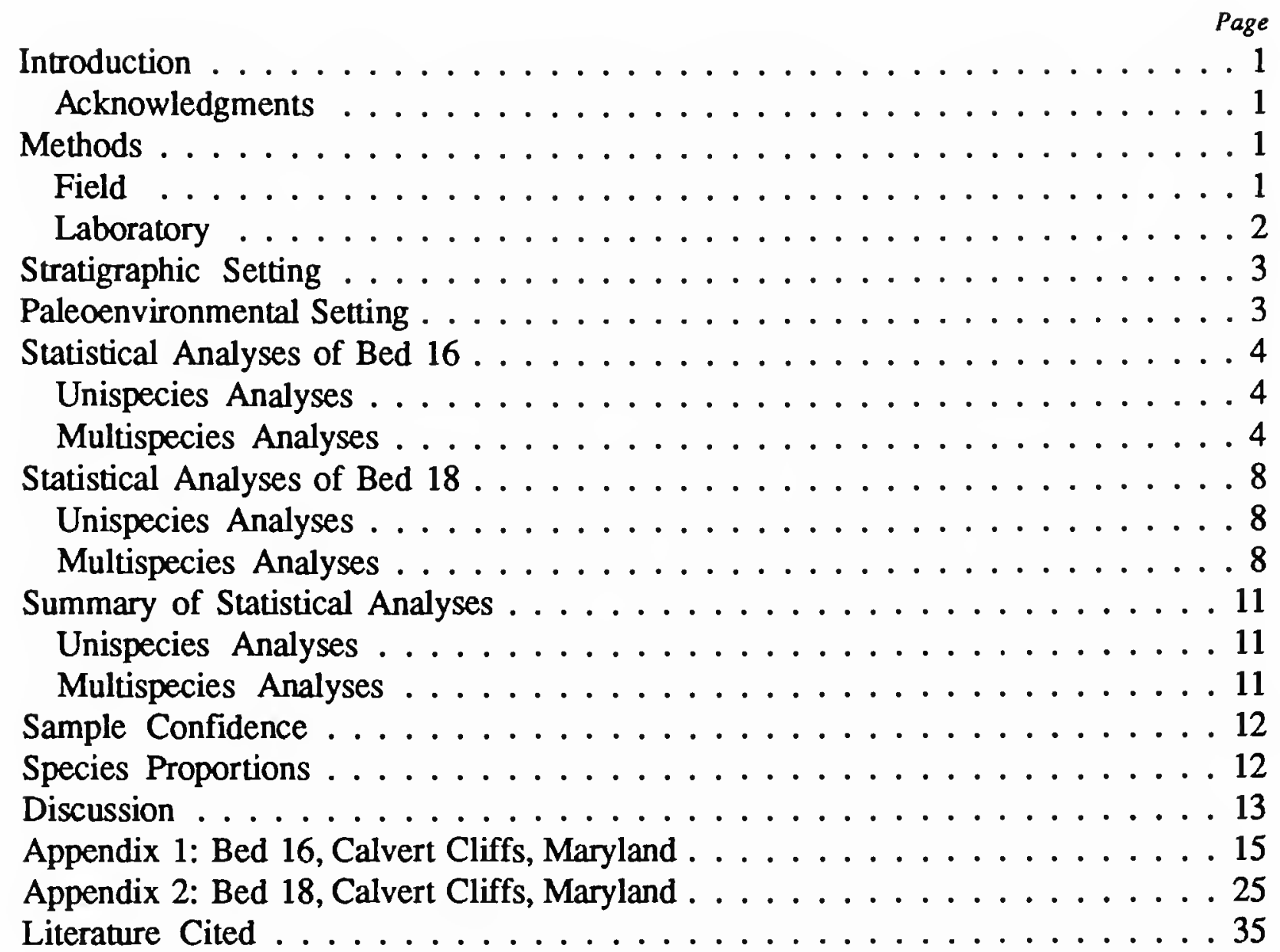




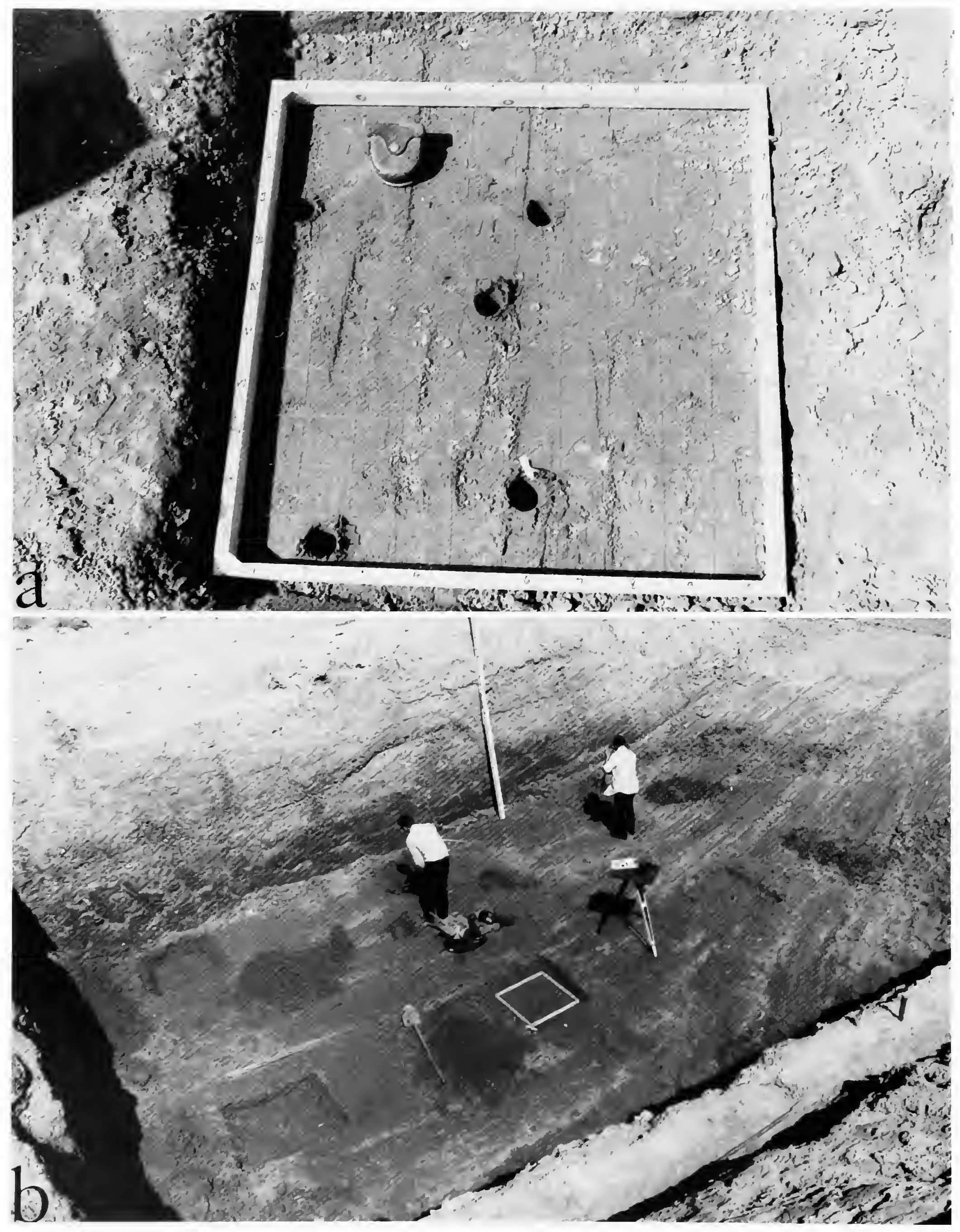

FRONTISPIECE. $\longrightarrow$, Sampling grid used for taking random samples in bed 18 (Brunton compass case for scale); $b$, excavation surface being sampled in bed 18 . 


\title{
Spatial Distribution of Miocene Foraminifera at Calvert Cliffs, Maryland
}

\author{
Martin A. Buzas and Thomas G. Gibson
}

\section{Introduction}

Theoretical, experimental, and field studies have demonstrated that within-habitat spatial patterns are important aspects of the adaptive strategies, survival, and evolution of organisms. In addition, knowledge of spatial distribution is essential for quantitative sampling. A basic question is whether organisms have different spatial distribution patterns in different environments or at different abundances.

Among terrestrial ecologists, spatial patterns have long been the subject of inquiry (Greig-Smith, 1964). In the marine realm, relatively few studies of within-habitat spatial patterns exist. During the past several decades researchers have taken an increasing interest in the spatial distribution of recent foraminiferal populations (Boltovskoy and Lena, 1969; Buzas, 1965, 1968, 1970; Lutze, 1968; Lynts, 1966; Olsson and Eriksson, 1974; Schafer, 1968, 1971; Shifflett, 1961). To our knowledge, however, only a few studies of spatial distribution on fossil foraminiferal populations exist (Scott, 1958; Schafer and Mudie, 1980; Smith and Buzas, 1986). In part, this is because neither outcrops nor coreholes provide the necessary large horizontal sampling surfaces for two-dimensional studies.

To adequately sample for patchiness in the fossil record, a relatively large surface area representing a bedding plane or single time of accumulation is needed. An artifical exposure in the Miocene Calvert and Choptank Formations in the Calvert Cliffs area on the western shore of the Chesapeake Bay in Maryland (Frontispiece) made during the construction of a nuclear power plant presented us with an unusual opportunity to sample the horizontal dimensions of fossil foraminiferal populations. Excavations for the power plant provided extensive horizontal surfaces at two stratigraphic levels in this classic area for middle Miocene strata. The larger horizontal

Martin A. Buzas, Department of Paleobiology, National Museum of Natural History, Smithsonian Institution, Washington, D.C. 20560. Thomas G. Gibson, US. Geological Survey, "970 National Center," Reston, Virginia 22092. surface is the lower stratigraphically, and allowed spatial sampling over a $400 \mathrm{~m}^{2}$ area. The slightly younger surface allowed sampling over a $50 \mathrm{~m}^{2}$ area. This paper presents the results of our analyses of the distribution of unispecies and multispecies populations in the two horizons at this site, and gives some insight into sampling reliability for studies in similar marine environments.

ACKNOWLEDGMENTS.-The opportunity for sampling was provided by the Baltimore Gas and Electric Company. Funding for part of the project was provided by the Maryland Academy of Science.

Laboratory assistance was given by Joyce Wilson, William Walker, and Kenneth Beem. Field assistance was provided by Thor Hansen and Lauck Ward. Constructive comments on the manuscript were provided by L. Collins, H. Dowsett, and R. Smith.

\section{Methods}

FIELD.-The large horizontal exposure $\left(>400 \mathrm{~m}^{2}\right)$ of the Calvert Formation utilized for the study of the lower horizon (in bed 16, following Shattuck (1904:lxxxi)) was located near the northern end of the construction area in a large excavation for the main water discharge channel for the power plant. As the dip of the strata is approximately $3 \mathrm{~m}$ per $1.6 \mathrm{~km}(10 \mathrm{ft}$ per $\mathrm{mi})$ to the southeast here, a plane table and alidade were used to determine a horizontal plane over the sampling area. Nine stations were marked in a 3- $\times 3$-station grid with a center to center spacing of $9.5 \mathrm{~m}(31.2 \mathrm{ft})$ between stations. Thus the grid had a total length of $19 \mathrm{~m}(62.3 \mathrm{ft})$ along each side. Although the desired center to center station spacing was $10 \mathrm{~m}(32.8 \mathrm{ft})$, the horizontal excavation would not accomodate so large a spacing. For the stations located in an updip-downdip orientation, a correction was made for the vertical difference of the bedding surface between stations because of the dip of the strata. As the dip is so low here, the necessary small vertical adjustment to uncover the same bedding surface at all stations 


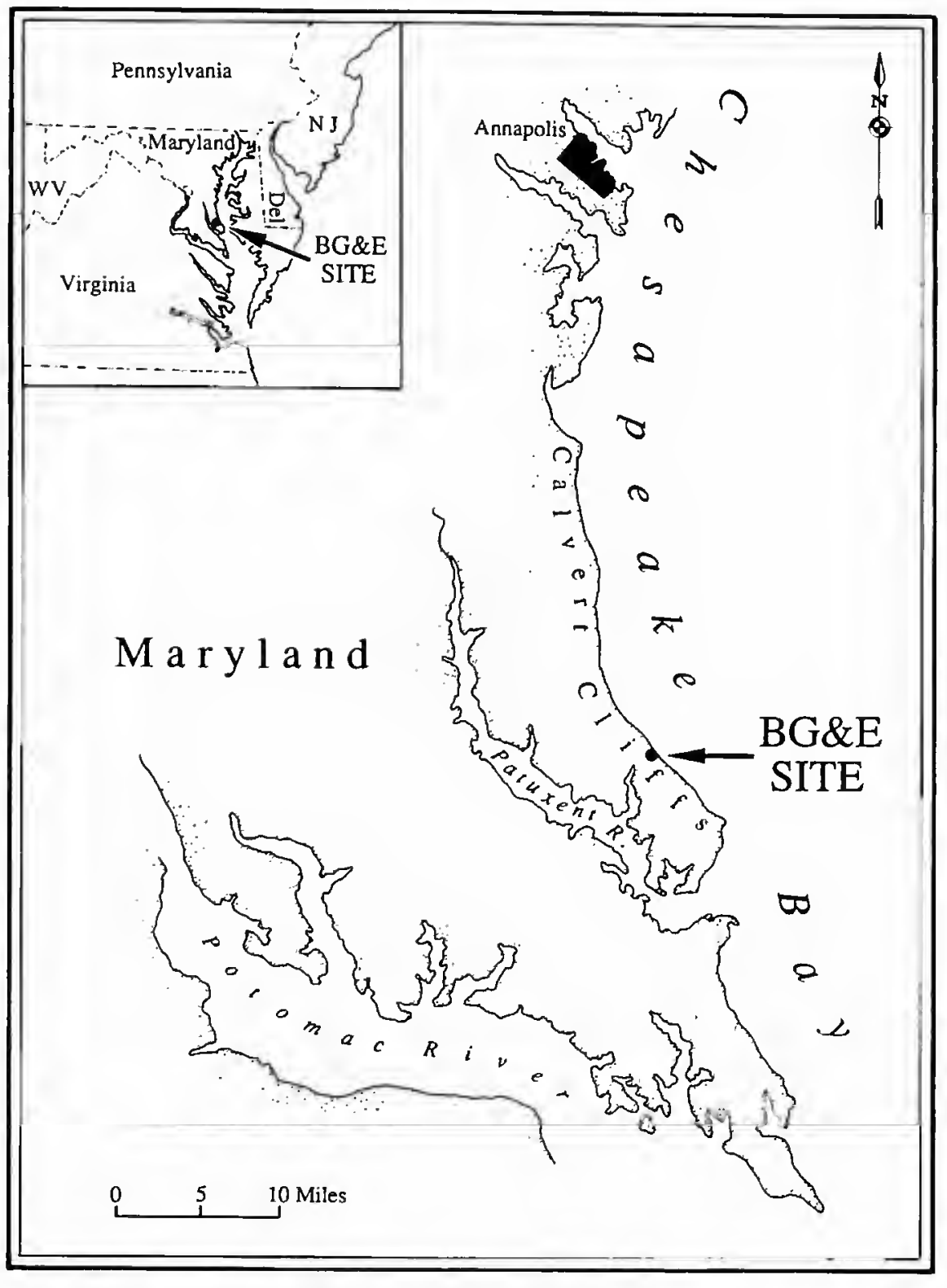

FIGURE 1.-Location of sampling site.

was done by hand shovel. Five samples were selected at random within a $1 \mathrm{~m}^{2}$ area centered around each station, resulting in a total of 45 samples from the 9 stations. The samples were $1 \mathrm{~cm}$ thick wafers and were taken with a plastic coring tube with an inner diameter of $3.5 \mathrm{~cm}$ that produced samples of $10 \mathrm{ml}$ in volume.

The second sampling surface was in bed 18 , as defined by Shattuck (1904:lxxxii) of the overlying Choptank Formation. It is approximately $9.1 \mathrm{~m}(30 \mathrm{ft})$ higher stratigraphically than bed 16. The surface was in one of a series of step-like exposures just to the north of the discharge channel. The smaller size of the excavation here limited the 9 stations in the 3- $\times 3$-station grid to a center to center spacing of $3.56 \mathrm{~m}(11.7 \mathrm{ft})$. The length of each side of the station grid was $7.1 \mathrm{~m}(23.3 \mathrm{ft})$. As for the first surface, a horizontal plane was established by the use of a plane table and alidade. Hand shovels were used to excavate all stations to the same bedding level, taking into account the dip of the strata.

Each station was excavated approximately 15 to $22 \mathrm{~cm}$ (6 to 9 in) below the possibly contaminated exposed surface to reach the same bedding level. Because the stations were relatively closely spaced in bed 18 , it was possible to follow the sampling

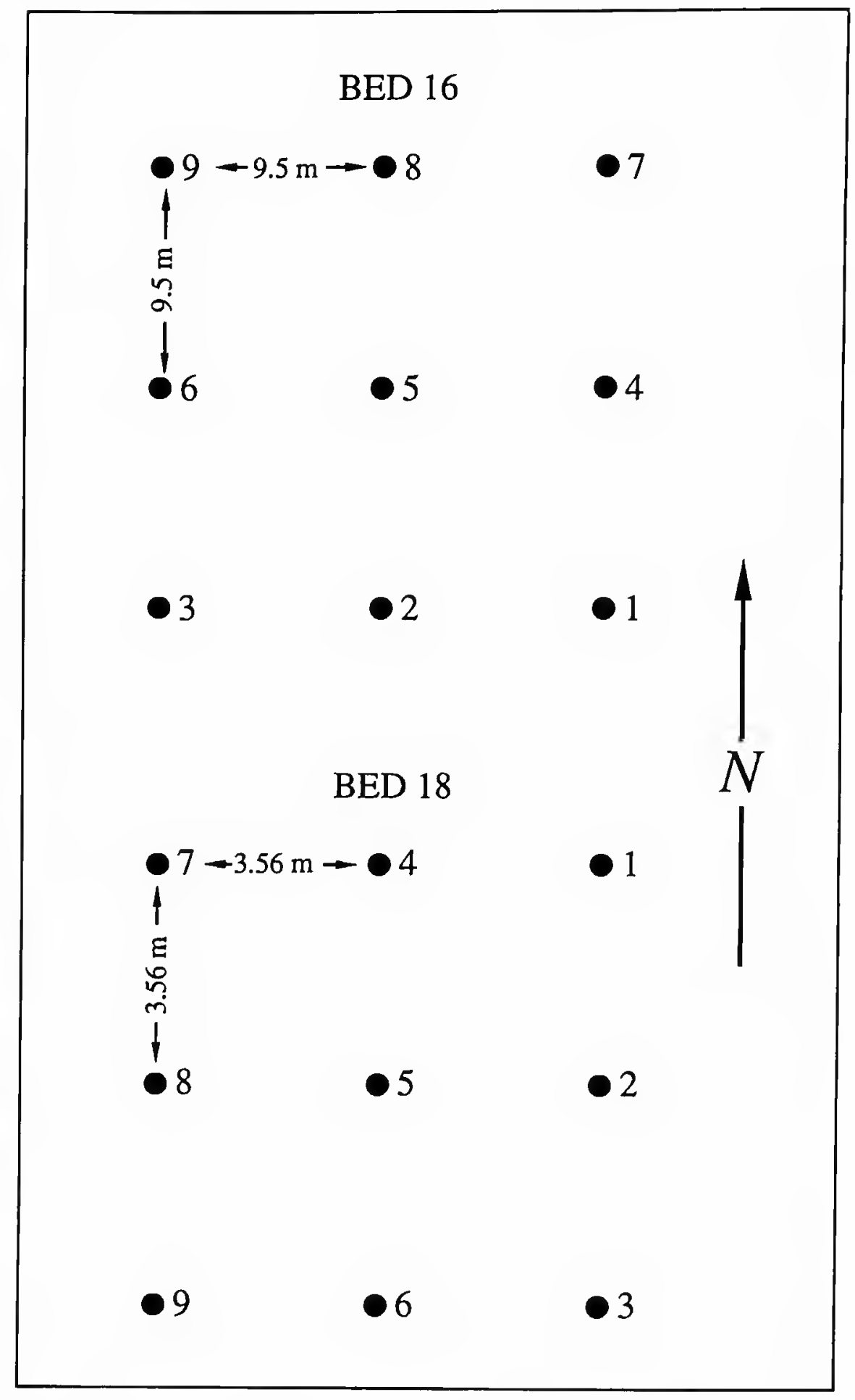

FIGURE 2.-Configuration of stations at the sampling sites in beds 16 and 18 .

level within approximately $1 \mathrm{~cm}$ among the stations. A moderately rapid accumulation rate for bed 18 is suggested by the following: a sedimentological homogeneity throughout the thickness of the bed; absence in the bed of shell concentrations and disconformities so common to the area (Kidwell, 1984); and the overall short time periods that the depositional sequences represent (Kidwell, 1984). The samples were taken at random with the aid of a 100-square grid centered on the station. The grid was constructed of a wooden frame $0.75 \mathrm{~m}$ square, which contained 9 horizontal and 9 vertical strings (Frontispiece, $a$ ). The 5 samples taken at each station were selected using random number tables. The 45 samples from the 9 stations also were $1 \mathrm{~cm}$ thick wafers taken with a $3.5 \mathrm{~cm}$ inner diameter plastic coring tube.

LABORATORY.-The $1 \mathrm{~cm}$ wafers of sediment were washed on a $63 \mu$ screen. Samples containing fewer than 300 specimens 
were picked completely; some samples containing more than 300 also were picked completely because of misjudgement of the number of specimens. Most samples containing more than 300-400 benthic specimens were split into an aliquot containing that number using a microsplitter. The specimens were then picked, placed onto faunal slides, and identified.

\section{Stratigraphic Setting}

The Miocene strata exposed in the Baltimore Gas and Electric nuclear power plant site include, in ascending order, the upper part of the Calvert Formation, the Choptank Formation, and the lower part of the St. Marys Formation.

Exposures of these Miocene formations along the Calvert Cliffs were studied in detail by Shattuck (1904). He set up a series of beds, or zones as he called them, on the basis of vertical changes in lithologic characteristics or relative quantity of fossil shells. Most of these beds can still be recognized in the Calvert Cliffs area, particularly in the vicinity of their designation; it becomes more difficult to recognize them in more updip outcrops along the Calvert Cliffs and in outcrops and coreholes away from this area because of facies changes.

The lower, larger bedding surface sampled was located approximately $0.76 \mathrm{~m}(2.5 \mathrm{ft})$ above the base of Shattuck's (1904) bed 16, which has since been placed within two formations by Kidwell (1984:40). The sample interval is a medium gray-green, slightly clayey, fine sand containing a few scattered shells, mainly Isognomon. In the area around the power plant site, Shattuck (1904:xi) stated a thickness for this bed of about $3.05 \mathrm{~m}(10 \mathrm{ft})$; the upper $2.6 \mathrm{~m}(8.5 \mathrm{ft})$ was exposed in the excavation. Shattuck (1904:1xxxi) considered bed 16 to be the basal bed of the Choptank Formation, with beds 17 through 20 comprising the remainder of the formation. Gernant (1970:10) named bed 16 the Calvert Beach Member on lithologic criteria and retained it as the basal part of the Choptank Formation. Kidwell (1984:40) placed bed 16 within a depositional sequence she termed PP-3. This prograding and shallowing-upward sequence starts with bed 14 of Shattuck (which Shattuck placed in the Calvert Formation) and continues upward through beds 15 and 16 to the base of bed 17 , which all workers place in the Choptank Formation. Kidwell (1984:40) considered the boundary between beds 16 and 17 to be an unconformity between two depositional sequences and thus placed bed 16 in the uppermost part of the Calvert Formation.

The upper, smaller bedding surface sampled was located 1.2 $\mathrm{m}(4 \mathrm{ft})$ below the top of bed 18 of Shattuck (1904) within the Choptank Formation. This interval is a gray-blue, slightly clayey, fine sand, heavily mottled because of bioturbation, and contains some scattered shells. Shattuck (1904:xi) gave a thickness of 5.49 to $6.70 \mathrm{~m}$ ( 18 to $22 \mathrm{ft}$ ) for the bed in this area, and Gernant (1970:68) gave a thickness of $5.86 \mathrm{~m}(19 \mathrm{ft}, 3 \mathrm{in})$ for a nearby section. Gernant (1970:17) named bed 18 the St. Leonard Member of the Choptank Formation on lithologic criteria. Kidwell (1984:40) also retained this bed in the Choptank Formation as part of her depositional sequence CT-0.

The general sparseness of pelagic microfossils in many intervals of the Miocene formations along the Calvert Cliffs has made it difficult to determine the exact age of many of the beds. However, the two beds in which we made the spatial distribution studies have recently been correlated with intercontinental zonations on the basis of their diatoms (Andrews, 1988). Both of the beds sampled are placed by Andrews (1988:4) in his East Coast Diatom Zone 6, the Rhaphoneis gemmifera zone. The lower sampled bed, bed 16 of Shattuck (1904), is placed in the lower part of this zone and is correlated with the lower part of planktonic foraminiferal zone N11 of Blow (1969:236) (middle middle Miocene, 13.5 mya, Berggren et al., 1985). The upper sampled bed, bed 18 of Shattuck (1904), is placed by Andrews (1988) in the upper part of the $R$. gemmifera zone, and is correlated with the upper part of planktic foraminiferal zone N11 of Blow (1969), also of middle middle Miocene age (13.0 mya).

\section{Paleoenvironmental Setting}

In addition to paleoenvironmental interpretations that can be drawn from the foraminifera and sedimentary characteristics observed in the present study, previous studies have been conducted on these beds. Studies were made by Gibson (1962) on foraminifera, Gernant (1970) on lithologic, microfaunal, and macrofaunal characteristics, Andrews (1976) on diatoms, Gibson (1983) on lithologic, foraminiferal, and regional characteristics, and Kidwell (1984) on lithologic characteristics and depositional sequences.

The most extensive paleoenvironmental study of the Choptank Formation is that of Gernant (1970). However, all of the above mentioned studies agree on the general environmental setting. The Choptank Formation, including the former usage of bed 16 as belonging there, is considered to represent deposition in well agitated, shallow marine environments, probably less than $60 \mathrm{~m}$ (197 ft) in depth. Some parts of the Choptank Formation, particularly the lower part of bed 16, are considered by Gernant (1970:46) to have formed in waters as deep as 45 to $60 \mathrm{~m}$ (148 to $197 \mathrm{ft}$ ). The upper beds of the Choptank Formation, including bed 18 in this area, are thought by Gernant (1970) to be depositions of even shallower environments, probably less than $30 \mathrm{~m}(98 \mathrm{ft})$ water depth.

The samples from the two horizons used in this study support these interpretations, as they consist of fairly well sorted, highly bioturbated sandy sediments containing a fairly low diversity benthic foraminiferal fauna (averaging 15 and 17 species per sample from beds 16 and 18, respectively) and having zero to two percent planktonic specimens. The average diversity values for the information function, $H(S)$, are 1.76 for the 45 samples from bed 16 and 1.68 for the 45 samples from bed 18; these values are typical of modern inner neritic assemblages in temperate environments (Gibson and Buzas, 
1973). The dominant modern species found in the bed 16 assemblages include Cibicides lobatulus, Bolivina paula, and Buliminella elegantissima. In bed 18 , the dominant species are Bolivina paula and Buliminella elegantissima with a considerably smaller percentage of Cibicides lobatulus. These assemblages indicate inner neritic environments with an abundance of organic carbon. The highly bioturbated sediment at both levels suggests that abundant organic carbon and moderate oxygen levels were present.

The paleoclimatic setting for these beds is postulated by Gibson (1962:72) and Gernant (1970:47), on the basis of foraminiferal and ostracode assemblages, as being of temperate nature, probably similar to that presently found off the Maryland coast.

\section{Statistical Analyses of Bed 16}

UNISPECIES ANALYSES. - The number of individuals, $x_{i j}$, for the stations $i=1,2, \ldots, 9$ and replicates $j=1,2, \ldots, 5$ for each of 36 species were enumerated. In all there are $\mathrm{N}=45$ observational samples of $p=36$ species from $h=9$ stations. Table 1 lists the 36 observed species and assigns each a number. To normalize the data and equalize the variance, the original variables were transformed to $\ln \left(x_{i j}+1\right)$. The original data are given in Appendix 1 (9 rarely occurring species were not used in the analysis). To gain some familiarity with the data being analyzed, the mean of $\ln \left(x_{i j}+1\right)$ for each of the 9 stations and 36 species is listed in Table 2 . To give the reader an idea of the number of individuals involved, $\ln 2=8, \ln 3=20, \ln 4=55$, and $\ln 5=150$.

In the present study, homogeneity within a bedding surface is defined as a lack of significant difference between the mean number of individuals at each station. A one-way analysis of variance (ANOVA) was carried out to test for the homogeneity of each species. The results of these 36 analyses are shown in Table 3. At the $p<.05$ level, for $F_{(8,36)}$ a value greater than 2.2 is considered significant. Species $1,5,7$, and 8 have significant values. Species 1 occurs in only 2 of our observations (both at the same station) and little importance can be attached to its large $F$ value.

Table 2 indicates that species 5,7 , and 8 are all relatively abundant species. With the exception of species 1 , which can be regarded as an anomaly, none of the rarer species is inhomogeneous. At the same time, a number of the more abundant species, $2,3,6$, and 12 , for example, are homogeneous. In general, on a species by species basis, we conclude that bed 16 is highly homogeneous.

MULTISPECIES ANALYSES.-In the unispecies analyses we defined homogeneity as being the lack of a significant difference between the mean number of individuals at each station. Similarly, homogeneity for the multispecies case is defined as a lack of significant difference between the mean vectors of species abundances at the 9 stations. In the
TABLE 1.--List of species from bed 16 used in statistical analysis.

\begin{tabular}{|c|c|}
\hline $\begin{array}{c}\text { Species } \\
\text { no. }\end{array}$ & Species \\
\hline 1 & Ammonia beccarii \\
\hline 2 & Textularia sp. \\
\hline 3 & Elphidium marylandicum \\
\hline 4 & Nonionella sp. \\
\hline 5 & Epistominella pontoni \\
\hline 6 & Valvulinaria floridana \\
\hline 7 & Rosalina cf. $R$. globularis \\
\hline 8 & Cibicides lobatulus \\
\hline 9 & Massilina glutinosa \\
\hline 10 & Spiroplectammina exilis \\
\hline 11 & Buliminella of. B. brevior \\
\hline 12 & Florilus pizarrense \\
\hline 13 & Cassidulina sp. \\
\hline 14 & Bolivina plicalella \\
\hline 15 & Fursenkoina sp. \\
\hline 16 & Uvigerina sp. \\
\hline 17 & Florilus chesapeakensis \\
\hline 18 & Anomalinoides? sp. \\
\hline 19 & Nonion cf. $N$. cassidulinoides \\
\hline 20 & Bolivina paula \\
\hline 21 & Buliminella elegantissima \\
\hline 22 & Caucasina sp. \\
\hline 23 & Lagena substriata \\
\hline 24 & Quinqueloculina sp. \\
\hline 25 & Fissurina lucida \\
\hline 26 & Lenticulina sp. and Marginulinopsis sp. \\
\hline 27 & Trifarina sp. \\
\hline 28 & Fissurina bidens \\
\hline 29 & Florilus cf. $F$. grateloupi \\
\hline 30 & Discorbis sp. \\
\hline 31 & Bolivina cf. B. marginala \\
\hline 32 & Lagena of. L. laevis \\
\hline 33 & Asterigerinala sp. \\
\hline 34 & Bolivina sp. \\
\hline 35 & Fissurina cf. $F$. marginata \\
\hline 36 & Pseudopolymorphina sp. \\
\hline
\end{tabular}

unispecies case we tested for homogeneity by ANOVA; a suitable extension to test for differences between the mean vectors is the multivariate analysis of variance (MANOVA). If differences do exist (multispecies population is heterogeneous), then a canonical variate analysis (CVA) can be utilized to discover which stations are similar and which are different (Seal, 1964; Buzas, 1966, 1967; Reyment et al., 1984). We have compressed the procedure somewhat and gone directly to a CVA because the test for the significance of the eigenvalues computes a $U$ variate, which is also an approximate test of the significance of a MANOVA (Seal, 1964). In other words, in evaluating the significance of the first eigenvalue in a CVA, we obtain the same $U$ variate as would be computed from the ratio of determinants in a MANOVA. Consequently, if the first eigenvalue of a CVA proves significant, we can be confident that there is a significant difference between the mean vector of species abundances. 
TABLE 2.-Mean vectors of species at nine stations in bed 16 .

\begin{tabular}{|c|c|c|c|c|c|c|c|c|c|}
\hline $\begin{array}{c}\text { Species } \\
\text { no. }\end{array}$ & 1 & 2 & 3 & 4 & $\begin{array}{l}\text { Station } \\
5\end{array}$ & 6 & 7 & 8 & 9 \\
\hline 1 & 0.00 & 0.00 & 0.00 & 0.00 & 0.36 & 0.00 & 0.00 & 0.00 & 0.00 \\
\hline 2 & 4.12 & 4.32 & 4.43 & 5.04 & 3.77 & 3.63 & 4.46 & 4.88 & 4.13 \\
\hline 3 & 3.26 & 2.44 & 2.49 & 3.04 & 2.68 & 2.38 & 3.10 & 2.88 & 3.20 \\
\hline 4 & 0.14 & 0.00 & 1.02 & 0.44 & 1.21 & 0.00 & 1.01 & 0.88 & 0.64 \\
\hline 5 & 4.42 & 5.10 & 4.95 & 5.54 & 5.03 & 5.05 & 5.49 & 5.63 & 5.57 \\
\hline 6 & 5.41 & 5.59 & 5.33 & 5.59 & 4.88 & 5.25 & 5.77 & 5.71 & 5.36 \\
\hline 7 & 3.15 & 3.09 & 2.75 & 3.19 & 2.33 & 2.79 & 2.90 & 3.76 & 1.02 \\
\hline 8 & 6.50 & 6.87 & 6.55 & 7.44 & 6.90 & 6.71 & 7.17 & 7.74 & 6.96 \\
\hline 9 & 0.58 & 0.00 & 0.00 & 0.57 & 0.00 & 0.44 & 0.44 & 1.70 & 0.57 \\
\hline 10 & 1.79 & 0.88 & 1.65 & 2.01 & 2.02 & 0.95 & 1.31 & 1.08 & 1.88 \\
\hline 11 & 0.14 & 0.00 & 0.00 & 0.00 & 0.00 & 0.00 & 0.00 & 0.57 & 0.00 \\
\hline 12 & 3.72 & 3.43 & 4.09 & 3.82 & 2.95 & 3.50 & 3.29 & 3.23 & 2.68 \\
\hline 13 & 1.18 & 1.57 & 0.32 & 1.58 & 2.00 & 1.20 & 1.44 & 2.66 & 0.96 \\
\hline 14 & 2.06 & 2.20 & 2.34 & 1.96 & 1.40 & 2.07 & 2.66 & 2.36 & 1.40 \\
\hline 15 & 0.14 & 0.00 & 0.00 & 0.57 & 0.00 & 0.00 & 0.44 & 0.00 & 0.00 \\
\hline 16 & 1.69 & 2.14 & 1.78 & 2.27 & 0.36 & 0.70 & 2.01 & 1.86 & 1.40 \\
\hline 17 & 1.80 & 1.72 & 1.20 & 1.01 & 1.78 & 1.40 & 2.34 & 2.09 & 1.40 \\
\hline 18 & 1.44 & 1.01 & 1.21 & 1.52 & 1.77 & 1.64 & 1.58 & 2.14 & 1.33 \\
\hline 19 & 0.22 & 0.00 & 0.00 & 0.44 & 0.14 & 0.00 & 0.00 & 0.44 & 0.44 \\
\hline 20 & 5.58 & 6.02 & 6.10 & 6.64 & 5.75 & 5.80 & 6.38 & 6.75 & 6.49 \\
\hline 21 & 5.02 & 5.36 & 5.49 & 5.52 & 5.16 & 4.91 & 5.36 & 5.68 & 5.89 \\
\hline 22 & 3.60 & 3.45 & 4.01 & 4.02 & 3.54 & 3.75 & 4.10 & 3.94 & 3.32 \\
\hline 23 & 0.22 & 0.32 & 0.00 & 0.00 & 0.00 & 0.00 & 0.00 & 0.00 & 0.00 \\
\hline 24 & 0.54 & 0.00 & 0.64 & 2.01 & 1.16 & 0.32 & 0.44 & 1.65 & 1.02 \\
\hline 25 & 2.06 & 0.89 & 2.23 & 1.32 & 0.72 & 0.32 & 1.44 & 0.88 & 0.76 \\
\hline 26 & 1.40 & 1.39 & 1.77 & 1.76 & 1.08 & 0.76 & 0.64 & 1.57 & 2.54 \\
\hline 27 & 0.89 & 0.00 & 0.00 & 0.00 & 0.76 & 0.76 & 0.00 & 0.00 & 0.00 \\
\hline 28 & 0.32 & 0.00 & 0.76 & 0.00 & 0.14 & 0.64 & 0.88 & 0.00 & 0.00 \\
\hline 29 & 0.00 & 0.00 & 0.00 & 0.44 & 0.00 & 0.44 & 0.00 & 0.00 & 0.00 \\
\hline 30 & 0.64 & 1.21 & 1.16 & 0.44 & 0.14 & 0.76 & 0.44 & 0.64 & 1.25 \\
\hline 31 & 0.32 & 0.00 & 0.00 & 0.00 & 0.44 & 0.00 & 0.44 & 0.57 & 0.00 \\
\hline 32 & 0.00 & 0.44 & 0.96 & 0.44 & 0.00 & 0.32 & 0.00 & 0.00 & 0.00 \\
\hline 33 & 0.00 & 0.44 & 0.00 & 0.44 & 0.00 & 0.00 & 0.57 & 0.00 & 0.44 \\
\hline 34 & 0.00 & 0.00 & 0.32 & 0.44 & 0.44 & 0.00 & 0.00 & 0.44 & 0.00 \\
\hline 35 & 0.00 & 0.00 & 0.57 & 0.00 & 0.44 & 0.44 & 0.44 & 0.00 & 0.00 \\
\hline 36 & 0.00 & 0.00 & 0.32 & 0.00 & 0.00 & 0.32 & 0.00 & 0.00 & 0.00 \\
\hline
\end{tabular}

To test whether all eigenvalues, $\varnothing_{j}$, after the $\mathrm{k}^{\text {th }}$ can be given 0 values, we evaluate

$$
[(\mathbb{N}-1)-1 / 2(p+h)] \ln \left[\prod_{j=k+1}^{m}\left(1+\phi_{j}\right)\right]
$$

which is distributed approximately as $\chi^{2}$ with $(\mathrm{p}-\mathrm{k})(\mathrm{h}-\mathrm{k}-1)$ degrees of freedom. In the present case $h=9$ stations, $N=45$ observations, and $\mathrm{p}=36$ species.

Table 4 lists the eigenvalues and the percent of the variability they account for. The value of $\chi^{2} .95,204$ is $\sim 288$ and we conclude the first three canonical variates, accounting for $96 \%$ of the variability, are significant. These variates are listed in Table 5, and the first two mean canonical variates are plotted in Figure 3. As might be expected, Figure 3 indicates most of the variability $(89 \%)$ is on the first axis. Stations 2 and 5 are distinct, 6,7 , and 8 form a cluster, and $1,3,4$, and 9 are strung out from this cluster with nearly equal distances between them. Examination of Table 2 does not clearly indicate why stations plot as they do in Figure 3. Likewise, areal plots of species abundances of selected species which contribute most of the value of the first canonical variate do not indicate that one or a few species are responsible for placement of the canonical axes. Rather, the species act collectively in a 36-dimensional space. Table 5 indicates there is not much contrast between the stations.

To examine the contributions that rare, abundant, and heterogeneously distributed species groups make to the CVA of 36 species, we decided to run three more analyses. The first deletes species $1,5,7$, and 8 , which proved heterogeneous in the ANOVA analyses; the second deletes rare species; and the third deletes abundant species. Abundant species are arbitrarily chosen as those with a grand mean of $\ln \left(x_{i j}+1\right)$ of greater than 
TABLE 3.-Analysis of variance for 36 species in bed 16 .

\begin{tabular}{|c|c|c|c|c|c|c|c|}
\hline Hypothesis & $\begin{array}{l}\text { Sum of } \\
\text { squares }\end{array}$ & $\begin{array}{l}\text { Mean } \\
\text { square }\end{array}$ & $F_{(8,36)}$ & Hypothesis & $\begin{array}{l}\text { Sum of } \\
\text { squares }\end{array}$ & $\begin{array}{l}\text { Mean } \\
\text { square }\end{array}$ & $F_{(8,36)}$ \\
\hline $\begin{array}{l}\text { Sp. } 1 \\
u_{1}=u_{2}=\ldots=u_{9} \\
\text { residual }\end{array}$ & $\begin{array}{l}0.57 \\
1.04\end{array}$ & $\begin{array}{l}0.07 \\
0.03\end{array}$ & 2.46 & $\begin{array}{l}\text { Sp. } 19 \\
u_{1}=u_{2}=\ldots=u_{9} \\
\text { residual }\end{array}$ & $\begin{array}{r}1.67 \\
12.94\end{array}$ & $\begin{array}{l}0.21 \\
0.36\end{array}$ & 0.58 \\
\hline $\begin{array}{l}\text { Sp. } 2 \\
u_{1}=u_{2}=\ldots=u_{9} \\
\text { residual }\end{array}$ & $\begin{array}{r}8.59 \\
31.21\end{array}$ & $\begin{array}{l}1.07 \\
0.87\end{array}$ & 1.24 & $\begin{array}{l}\text { Sp. } 20 \\
u_{1}=u_{2}=\ldots=u_{9} \\
\text { residual }\end{array}$ & $\begin{array}{r}6.98 \\
15.53\end{array}$ & $\begin{array}{l}0.87 \\
0.43\end{array}$ & 2.02 \\
\hline $\begin{array}{l}\text { Sp. } 3 \\
u_{1}=u_{2}=\ldots=u_{9} \\
\text { residual }\end{array}$ & $\begin{array}{r}4.61 \\
45.10\end{array}$ & $\begin{array}{l}0.51 \\
1.25\end{array}$ & 0.46 & $\begin{array}{l}\text { Sp. } 21 \\
u_{1}=u_{2}=\ldots=u_{9} \\
\text { residual }\end{array}$ & $\begin{array}{r}3.97 \\
23.60\end{array}$ & $\begin{array}{l}0.50 \\
0.66\end{array}$ & 0.76 \\
\hline $\begin{array}{l}\text { Sp. } 4 \\
u_{1}=u_{2}=\ldots=u_{9} \\
\text { residual }\end{array}$ & $\begin{array}{r}8.71 \\
46.71\end{array}$ & $\begin{array}{l}1.10 \\
1.30\end{array}$ & 0.84 & $\begin{array}{l}\text { Sp. } 22 \\
u_{1}=u_{2}=\ldots=u_{9} \\
\text { residual }\end{array}$ & $\begin{array}{r}3.17 \\
28.12\end{array}$ & $\begin{array}{l}0.40 \\
0.78\end{array}$ & 0.51 \\
\hline $\begin{array}{l}\text { Sp. } 5 \\
u_{1}=u_{2}=\ldots=u_{9} \\
\text { residual }\end{array}$ & $\begin{array}{r}6.34 \\
11.36\end{array}$ & $\begin{array}{l}0.79 \\
0.32\end{array}$ & 2.51 & $\begin{array}{l}\text { Sp. } 23 \\
u_{1}=u_{2}=\ldots=u_{9} \\
\text { residual }\end{array}$ & $\begin{array}{l}0.60 \\
3.04\end{array}$ & $\begin{array}{l}0.07 \\
0.08\end{array}$ & 0.88 \\
\hline $\begin{array}{l}\text { Sp. } 6 \\
u_{1}=u_{2}=\ldots=u_{9} \\
\text { residual }\end{array}$ & $\begin{array}{r}2.97 \\
10.23\end{array}$ & $\begin{array}{l}0.37 \\
0.28\end{array}$ & 1.31 & $\begin{array}{l}\text { Sp. } 24 \\
u_{1}=u_{2}=\ldots=u_{9} \\
\text { residual }\end{array}$ & $\begin{array}{l}17.10 \\
40.94\end{array}$ & $\begin{array}{l}2.14 \\
1.14\end{array}$ & 1.88 \\
\hline $\begin{array}{l}\text { Sp. } 7 \\
u_{1}=u_{2}=\ldots u_{9} \\
\text { residual }\end{array}$ & $\begin{array}{l}23.25 \\
39.17\end{array}$ & $\begin{array}{l}2.91 \\
1.09\end{array}$ & 2.67 & $\begin{array}{l}\text { Sp. } 25 \\
u_{1}=u_{2}=\ldots=u_{9} \\
\text { residual }\end{array}$ & $\begin{array}{l}16.32 \\
39.65\end{array}$ & $\begin{array}{l}2.04 \\
1.10\end{array}$ & 1.85 \\
\hline $\begin{array}{l}\text { Sp. } 8 \\
u_{1}=u_{2}=\ldots=u_{9} \\
\text { residual }\end{array}$ & $\begin{array}{r}6.65 \\
10.70\end{array}$ & $\begin{array}{l}0.83 \\
0.30\end{array}$ & 2.79 & $\begin{array}{l}\text { Sp. } 26 \\
u_{1}=u_{2}=\ldots=u_{9} \\
\text { residual }\end{array}$ & $\begin{array}{l}13.35 \\
50.91\end{array}$ & $\begin{array}{l}1.67 \\
1.41\end{array}$ & 1.18 \\
\hline $\begin{array}{l}\text { Sp. } 9 \\
u_{1}=u_{2}=\ldots=u_{9} \\
\text { residual }\end{array}$ & $\begin{array}{l}11.10 \\
34.79\end{array}$ & $\begin{array}{l}1.39 \\
0.96\end{array}$ & 1.44 & $\begin{array}{l}\text { Sp. } 27 \\
u_{1}=u_{2}=\ldots=u_{9} \\
\text { residual }\end{array}$ & $\begin{array}{r}6.51 \\
15.71\end{array}$ & $\begin{array}{l}0.81 \\
0.44\end{array}$ & 1.86 \\
\hline $\begin{array}{l}\text { Sp. } 10 \\
u_{1}=u_{2}=\ldots=u_{9} \\
\text { residual }\end{array}$ & $\begin{array}{r}8.40 \\
70.09\end{array}$ & $\begin{array}{l}1.05 \\
1.95\end{array}$ & 0.54 & $\begin{array}{l}\text { Sp. } 28 \\
u_{1}=u_{2}=\ldots=u_{9} \\
\text { residual }\end{array}$ & $\begin{array}{r}5.26 \\
15.88\end{array}$ & $\begin{array}{l}0.66 \\
0.44\end{array}$ & 1.49 \\
\hline $\begin{array}{l}\text { Sp. } 11 \\
u_{1}=u_{2}=\ldots=u_{9} \\
\text { residual }\end{array}$ & $\begin{array}{l}1.42 \\
6.81\end{array}$ & $\begin{array}{l}0.18 \\
0.19\end{array}$ & 0.94 & $\begin{array}{l}\text { Sp. } 29 \\
u_{1}=u_{2}=\ldots=u_{9} \\
\text { residual }\end{array}$ & $\begin{array}{l}1.50 \\
7.72\end{array}$ & $\begin{array}{l}0.19 \\
0.21\end{array}$ & 0.88 \\
\hline $\begin{array}{l}\text { Sp. } 12 \\
u_{1}=u_{2}=\ldots=u_{9} \\
\text { residual }\end{array}$ & $\begin{array}{r}7.65 \\
28.32\end{array}$ & $\begin{array}{l}0.96 \\
0.79\end{array}$ & 1.22 & $\begin{array}{l}\text { Sp. } 30 \\
u_{1}=u_{2}=\ldots=u_{9} \\
\text { residual }\end{array}$ & $\begin{array}{r}6.09 \\
15.88\end{array}$ & $\begin{array}{l}0.76 \\
1.30\end{array}$ & 0.59 \\
\hline $\begin{array}{l}\text { Sp. } 13 \\
u_{1}=u_{2}=\ldots=u_{9} \\
\text { residual }\end{array}$ & $\begin{array}{l}17.23 \\
47.58\end{array}$ & $\begin{array}{l}2.15 \\
1.32\end{array}$ & 1.63 & $\begin{array}{l}\text { Sp. } 31 \\
u_{1}=u_{2}=\ldots=u_{9} \\
\text { residual }\end{array}$ & $\begin{array}{r}2.32 \\
16.22\end{array}$ & $\begin{array}{l}0.29 \\
0.45\end{array}$ & 0.64 \\
\hline $\begin{array}{l}\text { Sp. } 14 \\
u_{1}=u_{2}=\ldots=u_{9} \\
\text { residual }\end{array}$ & $\begin{array}{r}7.17 \\
40.72\end{array}$ & $\begin{array}{l}0.90 \\
1.13\end{array}$ & 0.79 & $\begin{array}{l}\text { Sp. } 32 \\
u_{1}=u_{2}=\ldots=u_{9} \\
\text { residual }\end{array}$ & $\begin{array}{r}4.50 \\
12.90\end{array}$ & $\begin{array}{l}0.56 \\
0.36\end{array}$ & 1.57 \\
\hline $\begin{array}{l}\text { Sp. } 15 \\
u_{1}=u_{2}=\ldots=u_{9} \\
\text { residual }\end{array}$ & $\begin{array}{r}1.94 \\
10.67\end{array}$ & $\begin{array}{l}0.24 \\
0.30\end{array}$ & 0.82 & $\begin{array}{l}\text { Sp. } 33 \\
u_{1}=u_{2}=\ldots=u_{9} \\
\text { residual }\end{array}$ & $\begin{array}{r}2.53 \\
18.01\end{array}$ & $\begin{array}{l}0.32 \\
0.50\end{array}$ & 0.63 \\
\hline $\begin{array}{l}\text { Sp. } 16 \\
u_{1}=u_{2}=\ldots=u_{9} \\
\text { residual }\end{array}$ & $\begin{array}{l}17.03 \\
56.75\end{array}$ & $\begin{array}{l}2.13 \\
1.58\end{array}$ & 1.35 & $\begin{array}{l}\text { Sp. } 34 \\
u_{1}=u_{2}=\ldots=u_{9} \\
\text { residual }\end{array}$ & $\begin{array}{r}1.92 \\
13.66\end{array}$ & $\begin{array}{l}0.24 \\
0.38\end{array}$ & 0.63 \\
\hline $\begin{array}{l}\text { Sp. } 17 \\
u_{1}=u_{2}=\ldots=u_{9} \\
\text { residual }\end{array}$ & $\begin{array}{r}7.27 \\
67.27\end{array}$ & $\begin{array}{l}0.91 \\
1.87\end{array}$ & 0.49 & $\begin{array}{l}\text { Sp. } 35 \\
u_{1}=u_{2}=\ldots=u_{9} \\
\text { residual }\end{array}$ & $\begin{array}{r}2.53 \\
18.01\end{array}$ & $\begin{array}{l}0.32 \\
0.50\end{array}$ & 0.63 \\
\hline $\begin{array}{l}\text { Sp. } 18 \\
u_{1}=u_{2}=\ldots=u_{9} \\
\text { residual }\end{array}$ & $\begin{array}{r}4.36 \\
60.81\end{array}$ & $\begin{array}{l}0.54 \\
1.69\end{array}$ & 0.32 & $\begin{array}{l}\text { Sp. } 36 \\
u_{1}=u_{2}=\ldots=u_{9} \\
\text { residual }\end{array}$ & $\begin{array}{l}0.80 \\
4.14\end{array}$ & $\begin{array}{l}0.10 \\
0.11\end{array}$ & 0.88 \\
\hline
\end{tabular}



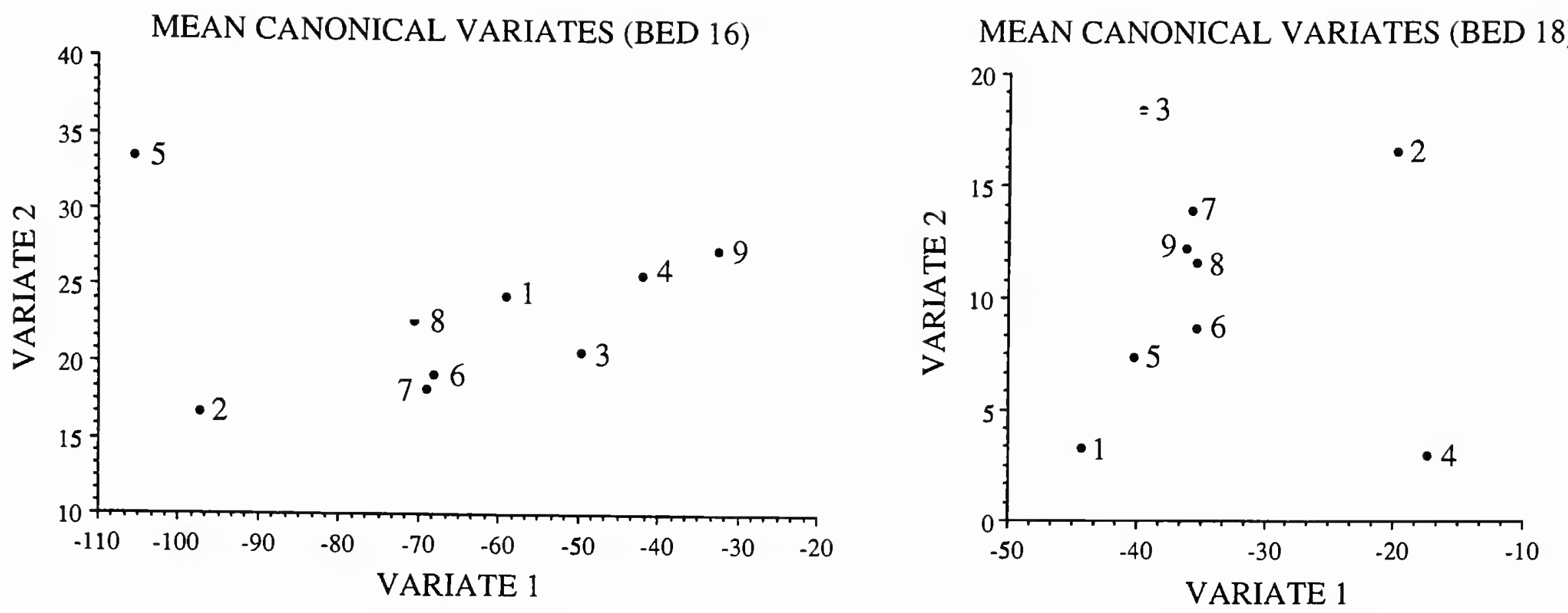

FIGURE 3.-Mean canonical variates 1 and 2 for bed 16 and bed 18 .

TABLE 4. - Eigenvalues and percentage of total variability for canonical variate analysis of 36 species in bed 16.

\begin{tabular}{c|cc}
\hline Order & Eigenvalue & $\begin{array}{l}\text { Percent of } \\
\text { variability }\end{array}$ \\
\hline 1 & 637.99 & 89.35 \\
2 & 30.63 & 4.29 \\
3 & 21.09 & 2.95 \\
4 & 8.76 & 1.22 \\
5 & 7.34 & 1.02 \\
6 & 4.15 & 0.58 \\
7 & 2.45 & 0.34 \\
8 & 1.53 & 0.21 \\
\hline
\end{tabular}

TABLE 5.-Mean canonical variates for bed 16.

\begin{tabular}{c|ccc}
\hline Station & Variate 1 & Variate 2 & Variate 3 \\
\hline 1 & -59.09 & 24.36 & -24.93 \\
2 & -97.51 & 16.67 & -34.79 \\
3 & -49.71 & 20.65 & -25.37 \\
4 & -42.00 & 25.82 & -38.01 \\
5 & -105.50 & 33.39 & -30.41 \\
6 & -68.08 & 19.19 & -28.91 \\
7 & -69.12 & 18.18 & -33.34 \\
8 & -70.59 & 22.70 & -33.39 \\
9 & -32.59 & 27.42 & -33.26 \\
\hline
\end{tabular}

1 and rare species of less than 1 . In terms of relative abundance, the abundant species account for $92 \%$ of the fauna. The eigenvalues of the CVA's are shown in Table 6 with their respective percentages of total variability. In all cases, the first eigenvalue accounts for much less of the total variability than the first eigenvalue of the CVA of all 36 species. In the original analysis the cumulative percentage of the first three eigenvalues was $96 \%$ whereas for the deleted analyses they are $70 \%$, $77 \%$, and $72 \%$, respectively.

The significance of the eigenvalues was evaluated by equation (1). For the analysis deleting heterogeneous species 1 , 5,7 , and 8 , we obtained a value of 263.29 with 256 degrees of freedom for the first eigenvalue. The value of $\chi^{2}{ }_{.95}, 256$ is $\sim 294$,

TABLE 6. -Eigenvalues and percentage of total variability for canonical variate analyses with deleted species, bed 16 .

\begin{tabular}{|c|c|c|c|c|c|c|}
\hline \multirow[t]{2}{*}{ Order } & \multicolumn{2}{|c|}{$\begin{array}{c}\text { Delete species } \\
\begin{array}{c}1,5,7,8 \\
p=32\end{array}\end{array}$} & \multicolumn{2}{|c|}{$\begin{array}{l}\text { Delete rare } \\
\text { species } \\
p=18\end{array}$} & \multicolumn{2}{|c|}{$\begin{array}{c}\text { Delete abundant } \\
\text { species } \\
p=18\end{array}$} \\
\hline & $\begin{array}{l}\text { Eigen- } \\
\text { value }\end{array}$ & $\%$ & $\begin{array}{l}\text { Eigen- } \\
\text { value }\end{array}$ & $\%$ & $\begin{array}{l}\text { Eigen- } \\
\text { value }\end{array}$ & $\%$ \\
\hline 1 & 8.05 & 26.16 & 4.78 & 40.24 & 2.65 & 35.08 \\
\hline 2 & 7.41 & 24.09 & 2.61 & 21.92 & 1.72 & 22.82 \\
\hline 3 & 6.16 & 20.02 & 1.87 & 15.73 & 1.14 & 15.04 \\
\hline 4 & 3.24 & 10.55 & 1.15 & 9.64 & 0.77 & 10.15 \\
\hline 5 & 2.55 & 8.30 & 0.77 & 6.51 & 0.71 & 9.43 \\
\hline 6 & 1.65 & 5.37 & 0.29 & 2.46 & 0.30 & 3.98 \\
\hline 7 & 1.04 & 3.38 & 0.25 & 2.14 & 0.18 & 2.44 \\
\hline 8 & 0.65 & 2.11 & 0.16 & 1.35 & 0.08 & 1.05 \\
\hline
\end{tabular}


and we conclude that deletion of the species deemed heterogeneous by the ANOVAs results in a homogeneous multispecies population. The first eigenvalue of the CVA deleting rare species yielded a value of 184.92 with 144 degrees of freedom, while $\chi^{2}{ }_{95,144}$ is 273.00 , indicating heterogeneity. Three of the 4 heterogeneous species are included among the abundant species in the analysis. Deleting the abundant species, a value of 142.56 is obtained for equation (1) with 144 degrees of freedom, indicating homogeneity.

The first mean canonical variates for each of the deleted analyses are shown in Table 7 . In comparing these variates with one another and with the variates shown in Table 5, it should be kept in mind that the "confidence interval" for each is about \pm 0.9 . Clearly, the range of values of canonical variates in the deleted analyses are much smaller than in the non-deleted analysis. When all species are included, the amount of discrimination between stations is much larger than for any of the deleted analyses. The analysis with the rare species deleted is barely significant, and although it includes 3 of the 4 heterogeneous ANOVA species, it shows little discrimination; the pattern observed in Figure 3 is not present, indicating the overall important contribution the rare species make to the pattern observed in the original analysis.

\section{Statistical Analyses of Bed 18}

UNISPECIES ANALYSES. - The procedure followed for the analysis of bed 18 is identical to that followed for bed 16 . Once again there are $N=45$ observational samples from $h=9$ stations; however, the number of species analyzed is $p=33$, or 3 fewer. The original data are given in Appendix 2 (12 rarely occurring species were not used in the analysis). Table 8 lists the species observed in bed 18 and Table 9 lists the mean vector of $\ln \left(x_{i j}+1\right)$ for each of the species at the 9 stations.

The results of the 33 ANOVAs are shown in Table 10. As before, an $\mathrm{F}$ value of greater than 2.2 is significant and indicates

TABLE 7.-First mean canonical variates for analyses with deleted species, bed 16.

\begin{tabular}{|c|c|c|c|}
\hline Station & $\begin{array}{c}\text { Delete species } \\
\begin{array}{c}1,5,7,8 \\
p=32\end{array}\end{array}$ & $\begin{array}{c}\text { Delete rare } \\
\text { species } \\
p=18\end{array}$ & $\begin{array}{c}\text { Delete abundant } \\
\text { species } \\
\mathrm{p}=18\end{array}$ \\
\hline & Variate 1 & Variate 1 & Variate 1 \\
\hline 1 & 6.12 & -9.32 & 1.60 \\
\hline 2 & 10.23 & -11.27 & 0.66 \\
\hline 3 & 11.46 & -9.18 & 1.06 \\
\hline 4 & 10.79 & -12.22 & -0.77 \\
\hline 5 & 3.28 & -15.11 & 4.38 \\
\hline 6 & 7.02 & -13.14 & 1.67 \\
\hline 7 & 7.72 & -12.49 & -0.21 \\
\hline 8 & 5.40 & -14.80 & -0.31 \\
\hline 9 & 7.42 & -12.15 & 0.34 \\
\hline
\end{tabular}

TABLE 8.-List of species from bed 18 used in statistical analysis.

\begin{tabular}{cl}
\hline Species & \multicolumn{1}{c}{ Species } \\
no. & Textularia sp. \\
\hline 1 & Elphidium marylandicum \\
2 & Valvulinaria floridana \\
3 & Buccella mansfieldi \\
4 & Cibicides lobalulus \\
5 & Discorbis bassleri \\
6 & Discorbis sp. \\
7 & Rosalina cf. $R$. globularis \\
8 & Epistominella pontoni \\
9 & Bolivina paula \\
10 & Buliminella elegantissima \\
11 & Caucasina sp. \\
12 & Uvigerina cf. U. subperegrina \\
13 & Bolivina plicatella \\
14 & Asterigerinata sp. \\
15 & Spiroplectammina sp. \\
16 & Florilus ? sp. \\
17 & Nonion cf. N. cassidulinoides \\
18 & Buliminella cf. B. brevior \\
19 & Buliminella cf. B. subfusiformis \\
20 & Bolivina cf. B. limbata \\
21 & Elphidium ? sp. \\
22 & Trifarina ? sp. \\
23 & Cassidulina sp. \\
24 & Bolivina cf. B. marginata \\
25 & Fissurina lucida \\
26 & Globocassidulina sp. \\
27 & Fursenkoina fusiformis \\
28 & Lagena laevis \\
29 & Astrononion sp. \\
30 & Florilus chesapeakensis \\
31 & Lagena sp. \\
32 & Lenticulina sp. \\
33 & \\
& \\
\hline &
\end{tabular}

heterogeneity. Only species 3 and 12 are heterogeneous, while species 2 and 20 are nearly so. Species 3 and 12 are relatively abundant species. None of the rarer species are inhomogeneous. As in bed 16, most of the abundant species are homogeneous.

In bed 16 species $1,5,7$, and 8 were heterogeneous. Species 1 does not occur in bed 18, but 5, 7, and 8 do and they are all homogeneously distributed. Similarly, in bed 18 species 3 and 12 are heterogeneous. Both of these species occur in bed 16 and are homogeneously distributed. Consequently, it seems likely that the very few significant ANOVAs are due to chance, which would be expected when calculating so many of them. The fact that the $F$ values were barely significant further supports this idea. On a species by species basis, we conclude bed 18 is highly homogeneous.

MULTISPECIES ANALYSES.-The procedure adopted for the multispecies analyses of bed 18 is also exactly that of bed 16 . In this instance, the number of species is $p=33$. Table 11 lists the eigenvalues, and the percentage of total variability. 
TABLE 9.-Mean vectors for species at 9 stations in bed 18.

\begin{tabular}{|c|c|c|c|c|c|c|c|c|c|}
\hline $\begin{array}{c}\text { Species } \\
\text { no. }\end{array}$ & 1 & 2 & 3 & 4 & $\begin{array}{c}\text { Station } \\
5\end{array}$ & 6 & 7 & 8 & 9 \\
\hline 1 & 3.06 & 2.97 & 3.39 & 2.70 & 3.31 & 3.42 & 3.23 & 3.16 & 3.09 \\
\hline 2 & 1.51 & 2.04 & 2.41 & 1.31 & 2.12 & 2.14 & 2.06 & 2.20 & 2.02 \\
\hline 3 & 3.55 & 3.06 & 3.16 & 2.86 & 3.68 & 3.77 & 3.22 & 3.42 & 3.51 \\
\hline 4 & 3.30 & 3.36 & 3.27 & 3.12 & 3.50 & 3.44 & 3.08 & 3.46 & 3.21 \\
\hline 5 & 3.59 & 3.23 & 3.52 & 2.96 & 3.34 & 3.69 & 3.17 & 3.65 & 3.32 \\
\hline 6 & 3.10 & 2.31 & 3.08 & 2.19 & 2.67 & 2.81 & 2.38 & 2.46 & 2.16 \\
\hline 7 & 0.61 & 1.64 & 1.76 & 0.00 & 1.38 & 0.54 & 1.57 & 1.14 & 0.74 \\
\hline 8 & 0.98 & 0.85 & 1.00 & 1.57 & 1.26 & 1.70 & 1.21 & 1.48 & 2.08 \\
\hline 9 & 1.92 & 1.52 & 1.89 & 1.23 & 2.14 & 2.59 & 1.01 & 1.58 & 1.65 \\
\hline 10 & 5.69 & 5.14 & 5.60 & 4.85 & 5.58 & 5.90 & 5.10 & 5.39 & 5.40 \\
\hline 11 & 5.89 & 5.55 & 5.99 & 5.01 & 5.74 & 6.20 & 5.32 & 5.66 & 5.46 \\
\hline 12 & 1.37 & 0.58 & 1.86 & 1.11 & 0.72 & 1.72 & 1.04 & 1.32 & 1.58 \\
\hline 13 & 0.46 & 0.22 & 0.00 & 0.14 & 0.14 & 0.36 & 0.14 & 0.00 & 0.22 \\
\hline 14 & 1.22 & 0.82 & 1.21 & 0.46 & 1.12 & 1.59 & 1.24 & 1.26 & 0.82 \\
\hline 15 & 0.36 & 0.46 & 0.80 & 0.80 & 1.19 & 1.12 & 0.32 & 0.22 & 0.44 \\
\hline 16 & 0.00 & 0.22 & 0.54 & 0.22 & 0.22 & 0.00 & 0.00 & 0.00 & 0.44 \\
\hline 17 & 0.22 & 0.44 & 0.54 & 0.36 & 0.00 & 0.14 & 0.14 & 0.00 & 0.22 \\
\hline 18 & 0.36 & 0.00 & 0.22 & 0.00 & 0.00 & 0.22 & 0.00 & 0.00 & 0.00 \\
\hline 19 & 0.14 & 0.00 & 0.14 & 0.00 & 0.00 & 0.00 & 0.00 & 0.00 & 0.00 \\
\hline 20 & 0.22 & 0.00 & 0.14 & 0.60 & 0.22 & 0.90 & 0.00 & 0.22 & 0.22 \\
\hline 21 & 0.14 & 0.00 & 0.00 & 0.00 & 0.00 & 0.00 & 0.00 & 0.22 & 0.00 \\
\hline 22 & 0.22 & 0.00 & 0.22 & 0.00 & 0.00 & 0.00 & 0.22 & 0.00 & 0.00 \\
\hline 23 & 0.44 & 0.14 & 0.36 & 0.54 & 0.00 & 0.00 & 0.00 & 0.00 & 0.14 \\
\hline 24 & 0.54 & 0.28 & 0.14 & 0.54 & 1.12 & 0.32 & 0.68 & 0.68 & 0.22 \\
\hline 25 & 0.00 & 0.22 & 0.00 & 0.00 & 0.00 & 0.14 & 0.00 & 0.00 & 0.00 \\
\hline 26 & 0.00 & 0.22 & 0.14 & 0.00 & 0.14 & 0.32 & 0.14 & 0.32 & 0.14 \\
\hline 27 & 0.00 & 0.44 & 0.00 & 0.00 & 0.00 & 0.32 & 0.00 & 0.00 & 0.00 \\
\hline 28 & 0.00 & 0.00 & 0.00 & 0.00 & 0.22 & 0.22 & 0.00 & 0.00 & 0.22 \\
\hline 29 & 0.00 & 0.00 & 0.36 & 0.00 & 0.28 & 0.14 & 0.00 & 0.44 & 0.14 \\
\hline 30 & 0.00 & 0.00 & 0.22 & 0.00 & 0.00 & 0.00 & 0.00 & 0.22 & 0.00 \\
\hline 31 & 0.00 & 0.00 & 0.14 & 0.00 & 0.00 & 0.00 & 0.00 & 0.00 & 0.00 \\
\hline 32 & 0.00 & 0.00 & 0.00 & 0.14 & 0.00 & 0.22 & 0.00 & 0.00 & 0.00 \\
\hline 33 & 0.00 & 0.00 & 0.00 & 0.22 & 0.00 & 0.00 & 0.22 & 0.14 & 0.00 \\
\hline
\end{tabular}

Evaluation of equation (1) gives a value of 381.09 with 264 degrees of freedom for the first eigenvalue, 276.86 with 224 degrees of freedom for the second, and 195.81 with 186 degrees of freedom for the third. The value of $\chi^{2} .95,224$ is -260 and $\chi^{2}{ }_{.95,186}$ is -218 . We conclude that the first two canonical variates are significant and the multispecies population is heterogeneous. Table 12 lists and Figure 3 plots the first two canonical variates. Stations $5, \ldots, 9$ form a central group while stations $1, \ldots, 4$ are satellites.

To get some idea of the contribution various groups of species make to the CVA, we ran three more analyses. As with bed 16, the first deletes the species judged to be heterogeneous by the ANOVAs, the second deletes the rare species (same criterion as bed 16), and the third deletes the abundant species. The eigenvalues and percentage of variability they account for are listed in Table 13. Evaluation of the eigenvalues by equation (1) indicates the first two canonical variates are significant in the first analysis. The value of equation (1) for the first eigenvalue is 349.46 with 248 degrees of freedom, and for the second 260.15 with 210 degrees of freedom while $\chi^{2} .95,248$ is $\sim 287$ and $\chi^{2}{ }_{.95,210}$ is -244 . With all $\mathrm{p}=33$ species the first two variates accounted for $84 \%$ of the total variability; with $p$ $=31$ only $75 \%$ of the variability. We conclude that the heterogeneous species helped discriminate, but the overall similarities and differences are not oblitered by their deletion and, of course, unlike bed 16 , the multispecies population remains heterogeneous.

The analyses with rare species deleted produced a value of equation (1) for the first eigenvalue of 96.31 with 104 degrees of freedom while $\chi^{2}{ }_{.95,104}=128.80$. Therefore, the multispecies population consisting of only the abundant species, including the heterogeneous species 3 and 12 , is homogeneous.

The analysis with the abundant species (as in bed 16, 92\% ...) deleted gave a value of equation (1) for the first eigenvalue of 188.54 with 160 degrees of freedom, while $\chi^{2} .95,160$ is -185.84 . Thus, the CVA of the rare species indicates they are heterogeneous. Looking at Table 14 and keeping in mind that each canonical variate has a $95 \%$ confidence interval of about \pm 0.9 , we see that much of the discrimination afforded in the first two CVA's is missing. A plot of the first two canonical 
TABLE 10.-Analysis of variance for 33 species in bed 18.

\begin{tabular}{|c|c|c|c|c|c|c|c|}
\hline Hypothesis & $\begin{array}{l}\text { Sum of } \\
\text { squares }\end{array}$ & $\begin{array}{l}\text { Mean } \\
\text { square }\end{array}$ & $F_{(B, 36)}$ & Hypothesis & $\begin{array}{l}\text { Sum of } \\
\text { squares }\end{array}$ & $\begin{array}{l}\text { Mean } \\
\text { square }\end{array}$ & $F_{(8,36)}$ \\
\hline $\begin{array}{l}\text { Sp. } 1 \\
u_{1}=u_{2}=\ldots=u_{9} \\
\text { residual }\end{array}$ & $\begin{array}{r}2.04 \\
10.91\end{array}$ & $\begin{array}{l}0.26 \\
0.30\end{array}$ & 0.84 & $\begin{array}{l}\text { Sp. } 18 \\
u_{1}=u_{2}=\ldots=u_{9} \\
\text { residual }\end{array}$ & $\begin{array}{l}0.77 \\
2.98\end{array}$ & $\begin{array}{l}0.10 \\
0.08\end{array}$ & 1.17 \\
\hline $\begin{array}{l}\text { Sp. } 2 \\
u_{1}=u_{2}=\ldots=u_{9} \\
\text { residual }\end{array}$ & $\begin{array}{r}4.81 \\
10.58\end{array}$ & $\begin{array}{l}0.60 \\
0.29\end{array}$ & 2.04 & $\begin{array}{l}\text { Sp. } 19 \\
u_{1}=u_{2}=\ldots=u_{9} \\
\text { residual }\end{array}$ & $\begin{array}{l}0.15 \\
0.77\end{array}$ & $\begin{array}{l}0.02 \\
0.02\end{array}$ & 0.88 \\
\hline $\begin{array}{l}\text { Sp. } 3 \\
u_{1}=u_{2}=\ldots=u_{9} \\
\text { residual }\end{array}$ & $\begin{array}{l}3.63 \\
6.83\end{array}$ & $\begin{array}{l}0.45 \\
0.19\end{array}$ & 2.39 & $\begin{array}{l}\text { Sp. } 20 \\
u_{1}=u_{2}=\ldots=u_{9} \\
\text { residual }\end{array}$ & $\begin{array}{l}3.39 \\
7.44\end{array}$ & $\begin{array}{l}0.42 \\
0.21\end{array}$ & 2.05 \\
\hline $\begin{array}{l}\text { Sp. } 4 \\
u_{1}=u_{2}=\ldots=u_{9} \\
\text { residual }\end{array}$ & $\begin{array}{l}0.89 \\
4.75\end{array}$ & $\begin{array}{l}0.11 \\
0.13\end{array}$ & 0.84 & $\begin{array}{l}\text { Sp. } 21 \\
u_{1}=u_{2}=\ldots=u_{9} \\
\text { residual }\end{array}$ & $\begin{array}{l}0.27 \\
1.35\end{array}$ & $\begin{array}{l}0.03 \\
0.04\end{array}$ & 0.89 \\
\hline Sp. 5 & & & & Sp. 22 & & & \\
\hline $\begin{array}{l}u_{1}=u_{2}=\ldots=u_{9} \\
\text { residual }\end{array}$ & $\begin{array}{l}2.37 \\
7.52\end{array}$ & $\begin{array}{l}0.30 \\
0.21\end{array}$ & 1.42 & $\begin{array}{l}\mathrm{u}_{1}=\mathrm{u}_{2}=\ldots=\mathrm{u}_{9} \\
\text { residual }\end{array}$ & $\begin{array}{l}0.48 \\
2.90\end{array}$ & $\begin{array}{l}0.06 \\
0.08\end{array}$ & 0.75 \\
\hline $\begin{array}{l}\text { Sp. } 6 \\
u_{1}=u_{2}=\ldots=u_{9} \\
\text { residual }\end{array}$ & $\begin{array}{r}5.19 \\
19.85\end{array}$ & $\begin{array}{l}0.65 \\
0.55\end{array}$ & 1.18 & $\begin{array}{l}\text { Sp. } 23 \\
u_{1}=u_{2}=\ldots=u_{9} \\
\text { residual }\end{array}$ & $\begin{array}{l}1.81 \\
5.60\end{array}$ & $\begin{array}{l}0.23 \\
0.16\end{array}$ & 1.46 \\
\hline Sp. 7 & & & & Sp. 24 & & & \\
\hline $\begin{array}{l}u_{1}=u_{2}=\ldots=u_{9} \\
\text { residual }\end{array}$ & $\begin{array}{l}14.47 \\
37.82\end{array}$ & $\begin{array}{l}1.81 \\
1.05\end{array}$ & 1.72 & $\begin{array}{l}\mathrm{u}_{1}=\mathrm{u}_{2}=\ldots=\mathrm{u}_{9} \\
\text { residual }\end{array}$ & $\begin{array}{r}3.71 \\
13.01\end{array}$ & $\begin{array}{l}0.46 \\
0.36\end{array}$ & 1.28 \\
\hline Sp. 8 & & & & Sp. 25 & & & \\
\hline $\begin{array}{l}u_{1}=u_{2}=\ldots=u_{9} \\
\text { residual }\end{array}$ & $\begin{array}{r}6.32 \\
15.89\end{array}$ & $\begin{array}{l}0.79 \\
0.44\end{array}$ & 1.79 & $\begin{array}{l}\mathrm{u}_{1}=\mathrm{u}_{2}=\ldots=\mathrm{u}_{9} \\
\text { residual }\end{array}$ & $\begin{array}{l}0.27 \\
1.35\end{array}$ & $\begin{array}{l}0.03 \\
0.04\end{array}$ & 0.89 \\
\hline Sp. 9 & & & & Sp. 26 & & & \\
\hline $\begin{array}{l}\mathrm{u}_{1}=\mathrm{u}_{2}=\ldots=\mathrm{u}_{9} \\
\text { residual }\end{array}$ & $\begin{array}{r}9.06 \\
21.65\end{array}$ & $\begin{array}{l}1.13 \\
0.60\end{array}$ & 1.88 & $\begin{array}{l}\mathrm{u}_{1}=\mathrm{u}_{2}=\ldots=\mathrm{u}_{9} \\
\text { residual }\end{array}$ & $\begin{array}{l}0.54 \\
6.65\end{array}$ & $\begin{array}{l}0.07 \\
0.18\end{array}$ & 0.37 \\
\hline Sp. 10 & & & & Sp. 27 & & & \\
\hline $\begin{array}{l}u_{1}=u_{2}=\ldots=u_{9} \\
\text { residual }\end{array}$ & $\begin{array}{r}4.34 \\
13.54\end{array}$ & $\begin{array}{l}0.54 \\
0.38\end{array}$ & 1.44 & $\begin{array}{l}u_{1}=u_{2}=\ldots=u_{9} \\
\text { residual }\end{array}$ & $\begin{array}{l}1.16 \\
3.52\end{array}$ & $\begin{array}{l}0.14 \\
0.10\end{array}$ & 1.48 \\
\hline $\begin{array}{l}\text { Sp. } 11 \\
u_{1}=u_{2}=\ldots=u_{9} \\
\text { residual }\end{array}$ & $\begin{array}{r}5.25 \\
13.02\end{array}$ & $\begin{array}{l}0.66 \\
0.36\end{array}$ & 1.81 & $\begin{array}{l}\text { Sp. } 28 \\
u_{1}=u_{2}=\ldots=u_{9} \\
\text { residual }\end{array}$ & $\begin{array}{l}0.48 \\
2.90\end{array}$ & $\begin{array}{l}0.06 \\
0.08\end{array}$ & 0.75 \\
\hline Sp. 12 & & & & Sp. 29 & & & \\
\hline $\begin{array}{l}u_{1}=u_{2}=\ldots=u_{9} \\
\text { residual }\end{array}$ & $\begin{array}{r}7.65 \\
14.98\end{array}$ & $\begin{array}{l}0.96 \\
0.42\end{array}$ & 2.30 & $\begin{array}{l}u_{1}=u_{2}=\ldots=u_{9} \\
\text { residual }\end{array}$ & $\begin{array}{l}1.17 \\
4.80\end{array}$ & $\begin{array}{l}0.15 \\
0.13\end{array}$ & 1.09 \\
\hline $\begin{array}{l}\text { Sp. } 13 \\
u_{1}=u_{2}=\ldots=u_{9} \\
\text { residual }\end{array}$ & $\begin{array}{l}0.91 \\
6.14\end{array}$ & $\begin{array}{l}0.11 \\
0.17\end{array}$ & 0.67 & $\begin{array}{l}\text { Sp. } 30 \\
\mathrm{u}_{1}=\mathrm{u}_{2}=\ldots=\mathrm{u}_{9} \\
\text { residual }\end{array}$ & $\begin{array}{l}0.38 \\
1.93\end{array}$ & $\begin{array}{l}0.05 \\
0.05\end{array}$ & 0.86 \\
\hline $\begin{array}{l}\text { Sp. } 14 \\
u_{1}=u_{2}=\ldots=u_{9} \\
\text { residual }\end{array}$ & $\begin{array}{r}4.38 \\
16.16\end{array}$ & $\begin{array}{l}0.55 \\
0.45\end{array}$ & 1.22 & $\begin{array}{l}\text { Sp. } 31 \\
\mathrm{u}_{1}=\mathrm{u}_{2}=\ldots=\mathrm{u}_{9} \\
\text { residual }\end{array}$ & $\begin{array}{l}0.08 \\
0.38\end{array}$ & $\begin{array}{l}0.01 \\
0.01\end{array}$ & 1.00 \\
\hline $\begin{array}{l}\text { Sp. } 15 \\
u_{1}=u_{2}=\ldots=u_{9} \\
\text { residual }\end{array}$ & $\begin{array}{c}5.04 \\
15.47\end{array}$ & $\begin{array}{l}0.63 \\
0.43\end{array}$ & 1.47 & $\begin{array}{l}\text { Sp. } 32 \\
u_{1}=u_{2}=\ldots=u_{9} \\
\text { residual }\end{array}$ & $\begin{array}{l}0.27 \\
1.35\end{array}$ & $\begin{array}{l}0.03 \\
0.04\end{array}$ & 0.89 \\
\hline $\begin{array}{l}\text { Sp.16 } \\
u_{1}=u_{2}=\ldots=u_{9} \\
\text { residual }\end{array}$ & $\begin{array}{l}1.66 \\
6.68\end{array}$ & $\begin{array}{l}0.21 \\
0.18\end{array}$ & 1.12 & $\begin{array}{l}\text { Sp. } 33 \\
u_{1}=u_{2}=\ldots=u_{9} \\
\text { residual }\end{array}$ & $\begin{array}{l}0.39 \\
2.32\end{array}$ & $\begin{array}{l}0.05 \\
0.06\end{array}$ & 0.76 \\
\hline $\begin{array}{l}\text { Sp. } 17 \\
u_{1}=u_{2}=\ldots=u_{9} \\
\text { residual }\end{array}$ & $\begin{array}{l}1.40 \\
7.52\end{array}$ & $\begin{array}{l}0.18 \\
0.21\end{array}$ & 0.84 & & & & \\
\hline
\end{tabular}


TABLE 11.-Eigenvalues and percentage of total variability for canonical variate analysis of 33 species in bed 18 .

\begin{tabular}{c|cc}
\hline Order & Eigenvalue & $\begin{array}{l}\text { Percent of } \\
\text { variability }\end{array}$ \\
\hline 1 & 91.98 & 62.20 \\
2 & 32.89 & 22.24 \\
3 & 8.70 & 5.88 \\
4 & 6.04 & 4.08 \\
5 & 3.06 & 2.07 \\
6 & 2.40 & 1.62 \\
7 & 2.03 & 1.37 \\
8 & 0.73 & 0.49 \\
\hline
\end{tabular}

TABLE 12.-Mean canonical variates for bed 18.

\begin{tabular}{c|cc}
\hline Station & Variate 1 & Variate 2 \\
\hline 1 & -44.27 & 3.24 \\
2 & -19.96 & 16.54 \\
3 & -39.62 & 18.36 \\
4 & -17.34 & 2.96 \\
5 & -40.23 & 7.37 \\
6 & -35.38 & 8.67 \\
7 & -35.83 & 13.93 \\
8 & -35.35 & 11.56 \\
9 & -36.20 & 12.27 \\
\hline
\end{tabular}

TABLE 13.-Eigenvalues and percentage of total variability for canonical variate analyses with deleted species, bed 18.

\begin{tabular}{|c|c|c|c|c|c|c|}
\hline \multirow[t]{2}{*}{ Order } & \multicolumn{2}{|c|}{$\begin{array}{l}\text { Delete species } \\
\qquad \begin{array}{c}3 \text { and } 12 \\
P=31\end{array}\end{array}$} & \multicolumn{2}{|c|}{$\begin{array}{l}\text { Delete rare } \\
\text { species } \\
p=13\end{array}$} & \multicolumn{2}{|c|}{$\begin{array}{c}\text { Delete abundant } \\
\text { species } \\
\text { p }=20\end{array}$} \\
\hline & $\begin{array}{c}\text { Eigen- } \\
\text { value }\end{array}$ & $\%$ & $\begin{array}{l}\text { Eigen- } \\
\text { value }\end{array}$ & $\%$ & $\begin{array}{l}\text { Eigen- } \\
\text { value }\end{array}$ & $\%$ \\
\hline 1 & 40.30 & 48.69 & 1.96 & 33.28 & 4.36 & 38.70 \\
\hline 2 & 22.47 & 27.14 & 1.38 & 23.30 & 2.31 & 20.47 \\
\hline 3 & 8.28 & 10.01 & 1.22 & 20.59 & 2.21 & 19.60 \\
\hline 4 & 5.14 & 6.21 & 0.62 & 10.46 & 0.98 & 8.69 \\
\hline 5 & 3.04 & 3.68 & 0.39 & 6.59 & 0.46 & 4.08 \\
\hline 6 & 1.91 & 2.31 & 0.19 & 3.16 & 0.44 & 3.94 \\
\hline 7 & 1.03 & 1.24 & 0.11 & 1.90 & 0.30 & 2.63 \\
\hline 8 & 0.59 & 0.72 & 0.04 & 0.72 & 0.21 & 1.88 \\
\hline
\end{tabular}

variates indicates that stations 2 and 4-9 form a cluster while 1 and 3 remain distinct. We conclude that although the abundant species are homogeneous when considered alone, they contribute significantly to the discrimination observed.

\section{Summary of Statistical Analyses}

UNISPECIES ANALYSES.-1. Four of the 36 species observed in bed 16 are heterogeneous. Two of the 33 species observed in bed 18 are heterogeneous.

2. With one exception, all of the heterogeneous species are abundant. However, most of the abundant species are homogeneous.

3. We conclude both beds 16 and 18 are very homogeneous with respect to unispecies populations.

MULTISPECIES ANALYSES.- 1 . When all species are considered, the multispecies populations in bed 16 and bed 18 are heterogeneous. Canonical variate analysis indicates in bed 16 stations 6,7 , and 8 are similar, while in bed 18 stations 5-9 are similar.

2. When the four heterogeneous species of the unispecies analyses are deleted, the multispecies population of bed 16 is homogeneous. When the two heterogeneous species of the unispecies analyses are deleted, the multispecies population of bed 18 is heterogeneous. Moreover, canonical variate analysis indicates the pattern observed for bed 18 with all species included is preserved.

3. Deletion of 18 rare species from the bed 16 multispecies population indicates the abundant species are heterogeneous (barely significant). Canonical variate analysis indicates the pattern observed when all species were included is not preserved. Deletion of 20 rare species in bed 18 produced a multispecies population of homogeneous abundant species.

4. Deletion of 18 abundant species from the multispecies population of bed 16 indicates the rare species population is

TABLE 14.-Canonical variates for analyses with deleted species, bed 18.

\begin{tabular}{|c|c|c|c|c|c|c|}
\hline \multirow[t]{3}{*}{ Station } & \multirow{2}{*}{\multicolumn{2}{|c|}{$\begin{array}{c}\text { Delete species } \\
\begin{array}{c}3 \text { and } 12 \\
p=31\end{array} \\
\text { Variate }\end{array}$}} & \multirow{2}{*}{\multicolumn{2}{|c|}{$\begin{array}{c}\begin{array}{c}\text { Delete rare } \\
\text { species } \\
p=13\end{array} \\
\text { Variate }\end{array}$}} & \multirow{2}{*}{\multicolumn{2}{|c|}{$\begin{array}{c}\text { Delete abundant } \\
\text { species } \\
\mathrm{p}=20\end{array}$}} \\
\hline & & & & & & \\
\hline & 1 & 2 & 1 & 2 & 1 & 2 \\
\hline 1 & -26.84 & -18.78 & 3.71 & 0.55 & 2.99 & 3.41 \\
\hline 2 & -26.06 & -2.98 & 4.40 & -1.64 & -0.70 & 0.64 \\
\hline 3 & -36.38 & -8.60 & 6.78 & -0.09 & 4.63 & 1.52 \\
\hline 4 & -13.83 & -9.70 & 2.99 & 0.46 & 0.81 & -1.52 \\
\hline 5 & -28.84 & -15.49 & 2.05 & -1.10 & -0.81 & -0.16 \\
\hline 6 & -26.12 & -11.17 & 4.17 & 0.18 & -1.36 & -1.46 \\
\hline 7 & -31.10 & -9.35 & 4.61 & 0.47 & 0.56 & -0.73 \\
\hline 8 & -29.34 & -11.47 & 4.81 & 0.21 & -0.78 & 0.70 \\
\hline 9 & -28.79 & -8.23 & 3.39 & 2.28 & 0.60 & 0.03 \\
\hline
\end{tabular}


homogeneous. Deletion of 13 abundant species from the multispecies population of bed 18 indicates the rare species population is heterogeneous (barely significant). Canonical variate analysis indicates the pattern observed when all species were included is not preserved.

\section{Sample Confidence}

To estimate the confidence we can place in the estimated means of our samples, we calculated the mean, standard deviation, and standard error for 8 species in bed 16 . These parameters allow us to calculate the confidence intervals for the mean by

$$
\hat{\mu}-1.96\left(\frac{\hat{\sigma}}{\sqrt{n}}\right) \leq \mu \leq \hat{\mu}+1.96\left(\frac{\hat{\sigma}}{\sqrt{n}}\right)
$$

At the $95 \%$ level for the entire suite of samples, the estimate for the mean is accurate by about $\pm 17 \%$. If we were to take only one sample, as most paleontologists do, we would have a confidence for the mean of about $\pm 100 \%$. If we were to take four samples, we would have confidence for the mean of about $\pm 50 \%$.

These results may appear surprising, but they are in agreement with those found by Smith and Buzas (1986) for the Monterey Formation, and agree with calculations (Buzas, unpublished) made on data from modern faunas. Even though the foraminiferal assemblages in these beds are homogeneous, in that there is no significant difference in the means between stations, the variances are still large. As pointed out in the previous paragraph, however, this is a normal situation in nature.

\section{Species Proportions}

The species proportions (expressed here in percent) are relatively homogeneous among the 45 samples in each horizon. Many of the species are found homogeneously distributed in both horizons, although they may be at greater or lesser proportions at the two levels. The following generalities are derived from the data in the appendices.

1. The most dominant species (usually two to four) are always dominant at a particular sample level, although not always in the same rank order. For example, Cibicides lobatulus is the most dominant species in all samples from bed 16. The range in all 45 samples is from $27 \%$ to $68 \%$ (mean of $43 \%$ ). Bolivina paula varies from $8 \%$ to $29 \%$ (mean of $19 \%$ ), and is the second most dominant species in 44 of the 45 samples. The third ranked species is Valvulinaria floridana, with a range of $4 \%$ to $21 \%$ (mean of $10 \%$ ). Buliminella elegantissima usually is fourth ranked with a range of $2 \%$ to $20 \%$ (mean of $9 \%$ ). More variability appears in the rank order of the third and fourth species because their proportions are very similar; $V$. floridana is more dominant than $B$. elegantis- sima in 27 of the 45 samples.

This consistency in species proportions of the dominant species is also found in bed 18. Here only two species have dominant proportions, and the range of values of these are more similar than for the two most dominant species in bed 16 . Buliminella elegantissima has a range of $30 \%$ to $52 \%$ (mean of $42 \%$ ), and is the first ranked species in 39 of the samples and the second ranked in the other 6 samples. Bolivina paula has a range of $20 \%$ to $47 \%$ (mean of $33 \%$ ) and is first ranked in 6 samples and second in 39 samples.

Even though the percentages of a species remain similar within each horizon, they change considerably between the two levels. Buliminella elegantissima and Bolivina paula are dominant species at both levels, but they have considerably higher proportions in bed 18. The other two dominant species in bed $16, C$. lobatulus and $V$. floridana, have only moderate proportions in bed 18, with a particularly large change in $C$. lobatulus between the two levels.

2. The moderately frequent species, those from about $3 \%$ to $10 \%$ of the assemblage, remain in this category in most samples from one horizon. This pattern is exhibited in bed 16 by Epistominella pontoni, which has a range from $3 \%$ to $12 \%$ (mean of $7 \%$ ). In bed $18, E$. pontoni has consistently rare occurrences. Two species from bed 18 illustrate the homogeneity of moderately occurring species. One is Cibicides lobatulus, which has a range of $1 \%$ to $8 \%$ (mean of $4 \%$ ). The other is Valvulinaria floridana; in bed 18 , it has a range of $2 \%$ to $8 \%$ (mean of $4 \%$ ).

3. The rare species, those composing less than $3 \%$ of the assemblage, may occur in many or most of the samples, but remain rare. Some species, like Bolivina plicatella, Elphidium marylandicum, and Cassidulina sp., are found in most samples in both levels in consistently low proportions. Bolivina plicatella is found in 38 of the 45 samples from bed 16 and in 36 of the 45 samples from bed 18. Other species have consistently low proportions in all samples, but occur in considerably more samples in one horizon than in the other. These include Florilus chesapeakensis and Fissurina lucida. Still another situation is a species which is consistently of moderate proportions in one horizon and rare in the other. An example is Epistominella pontoni; it occurs in all 45 samples from bed 16 with a range of $3.3 \%$ to $12.4 \%$, and occurs in 42 samples from bed 18 with a range of $0.2 \%$ to $2.2 \%$.

4. The planktic percentage of the total assemblage in the samples remains consistently low. Planktic specimens are found in 24 of the 45 samples in bed 16 and in 26 of the 45 samples in bed 18 . In 49 of these 50 samples they compose between $0.1 \%$ to $1.0 \%$ of the assemblages, with the one other sample containing $2 \%$.

5 . The number of species per sample ranges from 13 to 25 in bed 16 and from 12 to 21 in bed 18. Some of this variation can be explained by the considerable difference in the number of specimens picked. The number of picked specimens usually is between 300 to 500, but some higher numbers are present with 
three samples having over 1,000 specimens. The larger size samples tend to have the larger species counts (Buzas, et al., 1977:55, 58). However, even within the samples with nearly equal numbers of specimens there is a variation in the number of species of $-50 \%$ because of the random addition of rare species.

\section{Discussion}

The work of researchers over the last two decades indicates that the distribution of living foraminiferal populations is often heterogeneous (Boltovskoy and Lena, 1969; Buzas, 1965, 1968, 1970; Lutze, 1968; Lynts, 1966; Olsson and Eriksson, 1974; Schafer, 1968; Shifflett, 1961). In the tradition of other ecologists, workers have attempted to define spatial patterns in terms of patches or clumps. Foraminiferal patches have been estimated in sizes ranging from less than $1 \mathrm{~m}^{2}$ to over $2,900 \mathrm{~m}^{2}$. Unfortunately, quantitative comparisons between studies are impossible because of lack of standardization of what is measured, distance between stations, sediment volume, analytical methods, and replication. To overcome this problem the present study was patterned after a study made by Buzas (1970) on living populations in Rehoboth Bay, Delaware. Buzas (1970) located stations $10 \mathrm{~m}$ apart in a 4- $\times$ 4-station grid; each was sampled with five replicates. Homogeneity was defined as a lack of significant difference between the densities at the 16 stations. Three of four species studied were heterogeneous. Contrasts between pairs and groups of stations were made in an attempt to map the area into patches. Although many contrasts were made, only one was statistically significant, indicating a higher density for one species at one station. The heterogeneity could not be expressed by mapping the area into subareas of high and low densities (patches). At first, this seems puzzling, but consideration of an earlier study indicates why this is so.

Buzas (1968) sampled modern foraminiferal assemblages in Rehoboth Bay with three sets of contiguous cells. Each set contains 36 cells with a total area of $58 \mathrm{~cm}^{2}$. An individual cell has an area of $1.6 \mathrm{~cm}^{2}$ and the volume of sediment sampled from each is $-2 \mathrm{ml}$. In the living population, a random distribution was found in 6 of 12 possible cases. Those species that were not random were aggregated (variance larger than the mean) and were successfully fitted by the negative binomial distribution. Figure 4 shows the distribution observed for two species in Rehoboth Bay. The number of individuals (dots) plotted in each of the 34 cells ( 2 cells could not be sampled) was observed, but because the actual position of individuals in the $2 \mathrm{ml}$ sample could not be determined, the individuals within each cell are plotted at random. The bottom set in Figure 4 is aggregated according to the statistical definition; the top random. However, patches or clumps are not discrete and can only be defined arbitrarily. Indeed, if an investigator wished, one could draw patches or clumps in the uppermost example even though the arrangement is statistically random. The difficulty lies in the fact that the distribution of foraminifera is
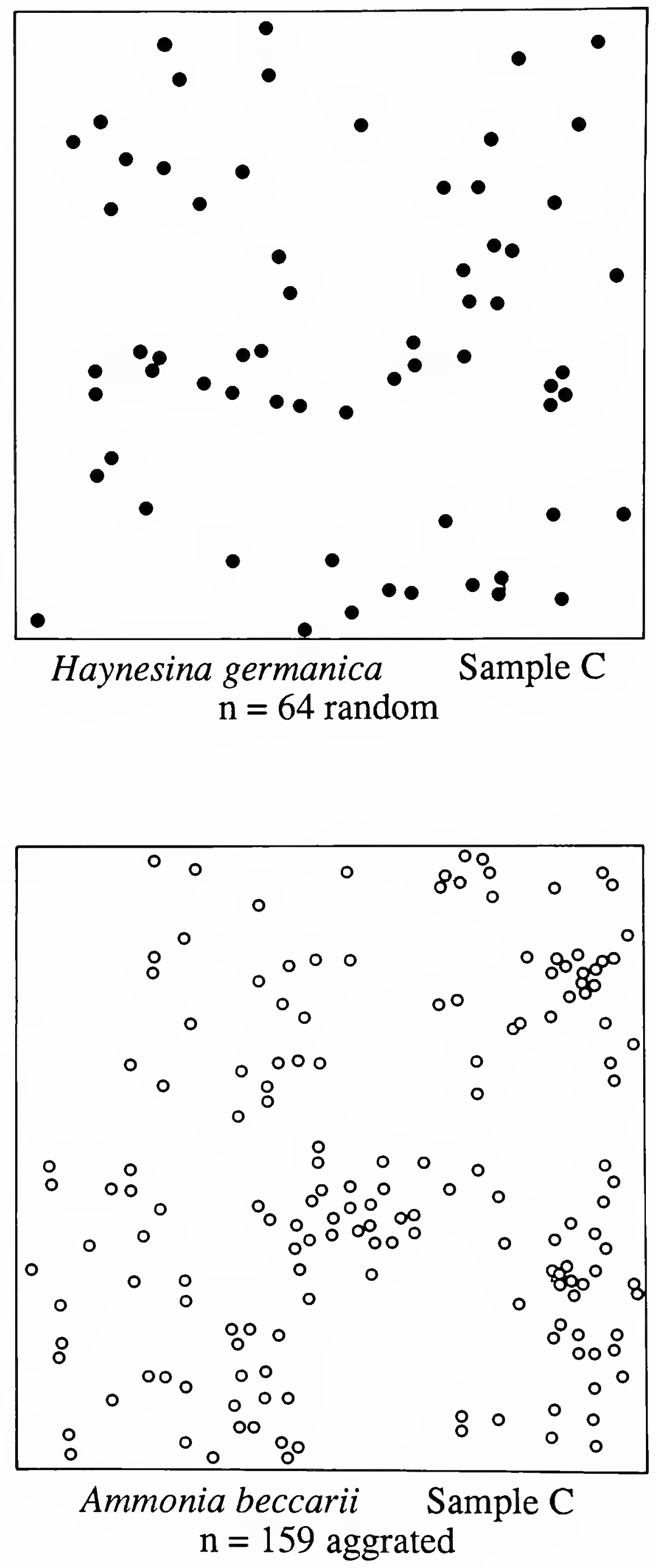

FIGURE 4. - Spatial distribution for two extant species in a $58 \mathrm{~cm}^{2}$ area in Rehoboth Bay, Delaware. 
in a continuum. When a sample is random it fits the Poisson distribution. When too many cells have too few individuals or when too many cells have too many individuals, the distribution does not fit the Poisson and is called aggregated or clumped. However, this does not mean that the individuals form neat aggregates (Figure 4). Rather, the distribution is in a continuum, with varying degrees of aggregation.

If the distribution of individuals in a sampling area is random (Poisson) or homogeneous (no significant difference between means), the area can be designated as a homogeneous patch. Yet, if the distribution is non-random or heterogeneous, no clear cut patches can be designated. The heterogeneity exists on a very small scale $(\mathrm{cm})$ and, even on this scale, discrete patches do not necessarily exist. Thus, contours on the number of individuals counted in single samples taken $1 \mathrm{~m}$ apart, and subsequent definition of high- and low-density patches (Boltovskoy and Lena, 1969; Lutze, 1968) are meaningless. When heterogeneity exists, the best one can hope for is to get some measure of the amount of heterogeneity. For organisms distributed heterogeneously within a habitat, the concept of a mosaic of discrete patches is not supported by observation. Rather, the organisms are distributed in a heterogeneous continuum.

The spatial distributions of total populations (living + dead) have not been studied as thoroughly as that of living populations. Available information indicates that like living populations, sometimes they are homogeneous and sometimes heterogeneous.

Shifflett (1961) gives data for the total specimen count of all species at 4 stations, each sampled with 3 replicates, from Heald Bank in the Gulf of Mexico. We calculated the coefficients of variation for the living population and total population at each of Shifflett's stations. In 3 of 4 cases the living population proved to be much more variable than the total population. In Long Island Sound, Buzas (1965, table 1) sampled 12 stations in duplicate. The total number of living specimens and the total number of specimens were tested for homogeneity. In the living population, 7 of 12 pairs were homogeneous while in the total, 5 of 12 were homogeneous, suggesting more homogeneity in the living population. The existing data are inadequate to draw any firm conclusions as to whether or not total populations are more homogeneous than living ones or whether different environments differ in their homogeneity.

Data on spatial distribution of fossil populations are also scant. Scott (1958) analyzed 25 samples located in a 5- $\times$ 5 -station grid, each sample was about $20 \mathrm{~cm}$ apart horizontally and $10 \mathrm{~cm}$ vertically in Oligocene strata of New Zealand. Fifteen species were enumerated, and an analysis of variance indicated that in the horizontal dimension 10 of 14 benthonic species were homogeneous.
Our results are in agreement with those of Scott (1958). In bed 16,32 of the 36 species observed were homogeneous, while in bed 18, 31 of 33 were homogeneous. This is a far greater degree of homogeneity than suggested by studies of living populations. In the only study that is statistically directly comparable, Buzas (1970) found 3 of the 4 species studied were heterogeneous in the living population. While not directly comparable because of differences in methodology and environment, other studies cited at the begining of "Discussion" also suggest more heterogeneity in living and total populations than observed in the fossil populations studied here. However, we must keep in mind that no suitable study on living and total populations in more equitable environments (such as the shallow marine environments of less than 60 or 30 $\mathrm{m}$ postulated for the fossil populations studied here) exists.

Another study of the spatial distribution of foraminiferal fossils was done on the Miocene Monterey Formation in California by Smith and Buzas (1986). Here 24 samples were taken $10 \mathrm{~cm}$ apart along the outcrop exposure of a single bed. The first 19 samples were judged to be similar using cluster analysis as criterion. Abruptly, at sample 20 (within $10 \mathrm{~cm}$ ) the densities (by an order of magnitude) and the species proportions changed (Smith and Buzas, 1986:11, fig. 2). Smith and Buzas (1986) could offer no suitable explanation for this phenomenon. It may be that this represents an unusual, low-oxygen environment, or one perhaps with winnowing.

Our analyses of the multispecies populations were surprisingly complex. The only study of living populations using a similar methodology is that of Buzas (1970). That study, however, had only 4 species ( 3 of which were heterogeneous) and was carried out in a marginal marine bay environment. The present study indicates that although the majority of the species studied are homogeneous on a unispecies basis, the multispecies populations are heterogeneous. Moreover, the removal of species judged heterogeneous on a unispecies basis does not insure multispecies homogeneity. Further, deletion of either abundant or rare species alters the patterns of similarities and differences between the mean vectors of species abundances, indicating discrimination is not on the basis of only a few species. Consequently, use of only a few "important" species in studying spatial patterns of multispecies populations must be viewed with caution.

Because we have no data on living and total populations in similar shallow open-ocean environments containing many species, the ecological and paleoecological significance of our analyses is unclear. While quantitative transformation from living to total to fossil populations is theoretically possible, no suitable data exist. We find ourselves in the paleontologically curious situation wherein studies of fossil populations are more comprehensive than any study of extant populations. 
Bed 16, Calvert Cliffs, Maryland

\begin{tabular}{|c|c|c|c|c|c|c|c|c|c|c|}
\hline \multirow[t]{3}{*}{ Samp le } & \multirow{2}{*}{\multicolumn{2}{|c|}{$\frac{\text { Textularla }}{\text { sp }}$}} & \multirow{2}{*}{\multicolumn{2}{|c|}{$\frac{\text { Elph Id lum }}{\text { maryland Icum }}$}} & \multirow{2}{*}{\multicolumn{2}{|c|}{$\frac{\text { Va I vu I Inar Ia }}{\text { flor Idana }}$}} & \multirow{2}{*}{\multicolumn{2}{|c|}{$\frac{\text { Clblcldes }}{\text { lobatulus }}$}} & \multicolumn{2}{|c|}{ Rosal ina } \\
\hline & & & & & & & & & R.g & obular is \\
\hline & $\mathscr{x}$ & no. & $\%$ & no. & $\%$ & no. & $\%$ & no. & $\%$ & no. \\
\hline $1-1$ & 3.5 & 41 & 1.2 & 14 & 12.2 & 144 & 37.0 & 437 & 0.9 & 11 \\
\hline $1-2$ & 2.7 & 88 & 1.2 & 40 & 12.6 & 408 & 37.8 & 1224 & 1.7 & 56 \\
\hline $1-3$ & 4.4 & 68 & 1.3 & 20 & 11.9 & 184 & 43.1 & 672 & 2.3 & 36 \\
\hline $1-4$ & 5.7 & 84 & 2.5 & 36 & 21.0 & 188 & 43.3 & 636 & 0.8 & 12 \\
\hline $1-5$ & 2.6 & 80 & 1.5 & 48 & 17.3 & 536 & 35.7 & 1112 & 1.3 & 40 \\
\hline $2-1$ & 2.7 & 72 & 1.5 & 40 & 12.7 & 336 & 37.2 & 984 & 0.6 & 16 \\
\hline $2-2$ & 2.0 & 36 & 0.9 & 16 & 14.1 & 248 & 37.4 & 656 & 0.5 & 8 \\
\hline $2-3$ & 6.5 & 152 & 0.7 & 16 & 11.3 & 264 & 45.5 & 1072 & 1.3 & 32 \\
\hline $2-4$ & 2.6 & 64 & 0.0 & 0 & 13.1 & 320 & 41.3 & 1008 & 1.6 & 40 \\
\hline $2-5$ & 3.7 & 88 & 0.7 & 16 & 8.0 & 192 & 49.8 & 1192 & 1.0 & 24 \\
\hline $3-1$ & 3.1 & 56 & 1.8 & 28 & 11.0 & 172 & 34.8 & 540 & 0.8 & 12 \\
\hline $3-2$ & 3.4 & 44 & 1.5 & 20 & 9.9 & 128 & 40.1 & 520 & 1.2 & 16 \\
\hline $3-3$ & 2.8 & 112 & 0.0 & 0 & 10.4 & 416 & 27.1 & 1088 & 1.2 & 48 \\
\hline $3-4$ & 5.3 & 160 & 0.8 & 24 & 11.7 & 352 & 34.4 & 1032 & 0.8 & 24 \\
\hline $3-5$ & 5.4 & 88 & 1.0 & 16 & 7.2 & 116 & 32.7 & 528 & 1.2 & 20 \\
\hline $4-1$ & 4.5 & 176 & 0.6 & 24 & 5.7 & 224 & 37.8 & 1480 & 1.0 & 40 \\
\hline $4-2$ & 3.2 & 104 & 0.7 & 24 & 7.9 & 256 & 50.0 & 1600 & 0.2 & 8 \\
\hline $4-3$ & 5.1 & 184 & 0.2 & 8 & 6.5 & 232 & 49.4 & 1768 & 0.4 & 16 \\
\hline $4-4$ & 6.1 & 224 & 1.1 & 40 & 13.7 & 504 & 43.9 & 1616 & 1.1 & 40 \\
\hline $4-5$ & 2.7 & 112 & 0.6 & 24 & 4.9 & 200 & 50.7 & 2080 & 0.8 & 32 \\
\hline $5-1$ & 2.2 & 61 & 0.5 & 14 & 6.9 & 191 & 61.4 & 1705 & 0.5 & 15 \\
\hline $5-2$ & 3.6 & 136 & 1.1 & 40 & 5.8 & 216 & 54.9 & 2048 & 0.4 & 16 \\
\hline $5-3$ & 0.0 & 0 & 1.1 & 2 & 9.0 & 16 & 53.9 & 96 & 0.0 & 0 \\
\hline $5-4$ & 2.8 & 104 & 1.1 & 40 & 4.6 & 168 & 50.1 & 1840 & 0.4 & 16 \\
\hline $5-5$ & 3.7 & 168 & 0.2 & 8 & 7.2 & 336 & 34.5 & 1584 & 0.5 & 24 \\
\hline $6-1$ & 1.5 & 24 & 1.5 & 24 & 7.3 & 116 & 68.3 & 1088 & 0.2 & 4 \\
\hline $6-2$ & 4.4 & 152 & 0.0 & 0 & 11.1 & 384 & 31.6 & 1096 & 1.2 & 40 \\
\hline $6-3$ & 1.7 & 28 & 1.0 & 16 & 11.9 & 200 & 50.1 & 844 & 1.0 & 16 \\
\hline $6-4$ & 1.6 & 20 & 1.6 & 20 & 12.0 & 152 & 37.5 & 476 & 1.9 & 24 \\
\hline $6-5$ & 1.4 & 32 & 0.7 & 16 & 8.0 & 180 & 34.3 & 772 & 0.5 & 12 \\
\hline $7-1$ & 1.4 & 40 & 0.9 & 24 & 9.3 & 256 & 53.8 & 1480 & 1.7 & 48 \\
\hline $7-2$ & 5.1 & 144 & 0.3 & 8 & 10.9 & 312 & 43.2 & 1232 & 1.7 & 48 \\
\hline $7-3$ & 1.1 & 40 & 0.4 & 16 & 10.6 & 384 & 38.6 & 1368 & 1.3 & 48 \\
\hline $7-4$ & 4.4 & 104 & 2.3 & 56 & 12.1 & 288 & 39.9 & 952 & 0.0 & 0 \\
\hline $7-5$ & 4.7 & 192 & 0.6 & 24 & 9.4 & 384 & 39.0 & 1584 & 0.4 & 16 \\
\hline $8-1$ & 3.1 & 112 & 1.3 & 48 & 7.5 & 272 & 53.6 & 1928 & 1.1 & 40 \\
\hline $8-2$ & 2.9 & 96 & 0.5 & 16 & 6.4 & 208 & 44.0 & 1432 & 0.5 & 16 \\
\hline $8-3$ & 1.9 & 96 & 0.0 & 0 & 8.5 & 432 & 46.2 & 2344 & 0.0 & 0 \\
\hline $8-4$ & 2.5 & 104 & 0.8 & 32 & 5.7 & 232 & 59.8 & 2448 & 1.4 & 72 \\
\hline $8-5$ & 4.6 & 352 & 0.8 & 64 & 5.7 & 432 & 52.3 & 3968 & 1.5 & 112 \\
\hline $9-1$ & 1.7 & 64 & 0.8 & 32 & 7.2 & 272 & 36.7 & 1376 & 0.0 & 0 \\
\hline $9-2$ & 2.5 & 44 & 0.9 & 16 & 8.6 & 148 & 30.6 & 532 & 0.8 & 12 \\
\hline $9-3$ & 1.3 & 32 & 2.1 & 52 & 8.2 & 208 & 40.3 & 976 & 0.5 & 12 \\
\hline $9-4$ & 5.6 & 336 & 0.6 & 32 & 5.8 & 352 & 39.0 & 2352 & 0.8 & 48 \\
\hline $9-5$ & 1.5 & 28 & 0.4 & 8 & 7.6 & 144 & 41.7 & 788 & 0.0 & 0 \\
\hline
\end{tabular}


Appendix 1.-Continued.

\begin{tabular}{|c|c|c|c|c|c|c|c|c|c|c|}
\hline \multirow[t]{2}{*}{ Sample } & \multicolumn{2}{|c|}{$\frac{\text { Eplstominel la }}{\text { ponton I }}$} & \multicolumn{2}{|c|}{$\frac{\text { BolIvIna }}{\text { paula }}$} & \multicolumn{2}{|c|}{$\frac{\text { BuIImIneIIa }}{\text { e legant Iss Ima }}$} & \multicolumn{2}{|c|}{$\frac{\text { Caucas Ina }}{s p}$} & \multicolumn{2}{|c|}{$\frac{\text { Non lone l I a }}{s p}$} \\
\hline & 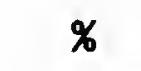 & no. & $\%$ & no. & $\%$ & no. & $\%$ & no. & $\%$ & no. \\
\hline$\overline{1-1}$ & 6.7 & 79 & 18.1 & 214 & 12.8 & 151 & 1.8 & 20 & 0.1 & 1 \\
\hline $1-2$ & 6.9 & 224 & 17.0 & 544 & 12.1 & 392 & 2.0 & 64 & 0.0 & 0 \\
\hline $1-3$ & 3.9 & 60 & 17.8 & 272 & 5.9 & 92 & 2.3 & 36 & 0.0 & 0 \\
\hline $1-4$ & 3.3 & 48 & 10.6 & 156 & 6.8 & 100 & 1.9 & 28 & 0.0 & 0 \\
\hline $1-5$ & 4.6 & 144 & 17.0 & 528 & 9.0 & 280 & 2.8 & 88 & 0.0 & 0 \\
\hline $2-1$ & 7.6 & 200 & 20.0 & 528 & 10.9 & 288 & 3.0 & 80 & 0.0 & 0 \\
\hline $2-2$ & 8.2 & 144 & 18.7 & 328 & 9.1 & 160 & 2.3 & 40 & 0.0 & 0 \\
\hline $2-3$ & 6.1 & 144 & 15.6 & 368 & 7.1 & 168 & 1.7 & 40 & 0.0 & 0 \\
\hline $2-4$ & 6.5 & 160 & 18.7 & 456 & 9.8 & 240 & 0.6 & 16 & 0.0 & 0 \\
\hline $2-5$ & 7.3 & 176 & 16.7 & 400 & 9.4 & 224 & 1.0 & 24 & 0.0 & 0 \\
\hline $3-1$ & 5.9 & 92 & 19.4 & 300 & 13.9 & 216 & 2.1 & 32 & 0.0 & 0 \\
\hline $3-2$ & 6.8 & 88 & 20.6 & 268 & 6.2 & 80 & 3.4 & 44 & 0.3 & 4 \\
\hline $3-3$ & 6.0 & 240 & 29.1 & 1168 & 16.3 & 656 & 1.2 & 48 & 0.8 & 32 \\
\hline $3-4$ & 6.1 & 184 & 18.4 & 552 & 10.4 & 312 & 5.1 & 152 & 0.0 & 0 \\
\hline $3-5$ & 9.4 & 152 & 21.3 & 344 & 14.1 & 228 & 2.8 & 44 & 0.0 & 0 \\
\hline $4-1$ & 8.0 & 312 & 26.5 & 1040 & 8.2 & 320 & 2.2 & 88 & 0.0 & 0 \\
\hline $4-2$ & 7.9 & 256 & 20.1 & 648 & 6.7 & 216 & 1.2 & 40 & 0.0 & 0 \\
\hline $4-3$ & 6.3 & 224 & 20.1 & 720 & 6.0 & 216 & 0.7 & 24 & 0.0 & 0 \\
\hline $4-4$ & 5.6 & 208 & 16.5 & 608 & 5.4 & 200 & 2.4 & 88 & 0.0 & 0 \\
\hline $4-5$ & 7.0 & 288 & 21.2 & 872 & 7.8 & 320 & 1.6 & 64 & 0.2 & 8 \\
\hline $5-1$ & 5.2 & 145 & 14.1 & 393 & 5.6 & 156 & 1.7 & 47 & 0.0 & 0 \\
\hline $5-2$ & 5.4 & 200 & 14.2 & 528 & 8.1 & 304 & 2.4 & 80 & 0.0 & 0 \\
\hline $5-3$ & 12.4 & 22 & 14.0 & 25 & 4.5 & 8 & 2.8 & 5 & 0.0 & 0 \\
\hline $5-4$ & 6.1 & 224 & 18.5 & 680 & 10.7 & 392 & 1.7 & 64 & 0.6 & 24 \\
\hline $5-5$ & 11.9 & 544 & 17.4 & 800 & 20.2 & 928 & 0.7 & 32 & 0.3 & 16 \\
\hline $6-1$ & 4.0 & 64 & 7.8 & 124 & 2.0 & 32 & 3.5 & 56 & 0.0 & 0 \\
\hline $6-2$ & 10.8 & 376 & 25.6 & 888 & 9.2 & 320 & 1.4 & 48 & 0.0 & 0 \\
\hline $6-3$ & 7.1 & 120 & 14.2 & 240 & 4.7 & 80 & 3.1 & 52 & 0.0 & 0 \\
\hline $6-4$ & 9.8 & 124 & 18.6 & 236 & 9.5 & 120 & 1.9 & 24 & 0.0 & 0 \\
\hline $6-5$ & 11.0 & 248 & 28.1 & 632 & 11.0 & 248 & 1.6 & 36 & 0.0 & 0 \\
\hline $7-1$ & 9.6 & 264 & 14.2 & 392 & 4.6 & 128 & 0.9 & 24 & 0.0 & 0 \\
\hline $7-2$ & 5.9 & 168 & 15.7 & 448 & 8.4 & 240 & 2.2 & 64 & 0.0 & 0 \\
\hline $7-3$ & 7.2 & 256 & 25.3 & 896 & 9.5 & 336 & 2.5 & 88 & 0.0 & 0 \\
\hline $7-4$ & 8.4 & 200 & 19.5 & 464 & 8.4 & 200 & 2.0 & 48 & 0.3 & 8 \\
\hline $7-5$ & 8.9 & 360 & 24.0 & 976 & 5.1 & 208 & 2.8 & 112 & 0.4 & 16 \\
\hline $8-1$ & 7.5 & 272 & 14.0 & 504 & 7.1 & 256 & 0.4 & 16 & 0.0 & 0 \\
\hline $8-2$ & 6.9 & 224 & 24.6 & 800 & 9.6 & 312 & 2.0 & 64 & 0.0 & 0 \\
\hline $8-3$ & 8.0 & 408 & 23.8 & 1208 & 6.9 & 352 & 1.0 & 56 & 0.2 & 8 \\
\hline $8-4$ & 4.3 & 176 & 15.4 & 632 & 3.9 & 160 & 2.1 & 88 & 0.2 & 8 \\
\hline $8-5$ & 5.1 & 384 & 19.4 & 1472 & 6.3 & 480 & 0.8 & 64 & 0.0 & 0 \\
\hline $9-1$ & 9.1 & 344 & 24.6 & 928 & 11.9 & 448 & 2.1 & 80 & 0.6 & 24 \\
\hline $9-2$ & 10.7 & 184 & 29.2 & 504 & 12.1 & 208 & 2.1 & 36 & 0.0 & 0 \\
\hline $9-3$ & 8.4 & 212 & 18.3 & 444 & 13.9 & 336 & 2.3 & 56 & 0.0 & 0 \\
\hline $9-4$ & 8.7 & 528 & 21.0 & 1264 & 13.5 & 816 & 1.6 & 96 & 0.0 & 0 \\
\hline $9-5$ & 9.3 & 176 & 25.0 & 472 & 12.7 & 240 & 0.0 & 0 & 0.0 & 0 \\
\hline
\end{tabular}


Appendix 1.-Continued.

\begin{tabular}{|c|c|c|c|c|c|c|c|c|c|c|}
\hline \multirow[t]{2}{*}{ Sample } & \multicolumn{2}{|c|}{$\frac{\text { Mass IIIna }}{\text { glut Inosa }}$} & \multicolumn{2}{|c|}{$\frac{\text { Sp Iroplectammina }}{\text { exil|s }}$} & \multicolumn{2}{|c|}{$\frac{\text { Florllus }}{\text { plzarrense }}$} & \multicolumn{2}{|c|}{$\frac{\text { Bollvina }}{\text { pllcatella }}$} & \multicolumn{2}{|c|}{$\frac{\text { Cass|duIIna }}{\text { sp. }}$} \\
\hline & $\%$ & no. & $\%$ & no. & $\%$ & no. & $\%$ & no. & $\%$ & no. \\
\hline $1-1$ & 0.1 & 1 & 0.5 & 6 & 1.7 & 20 & 0.2 & 2 & 0.6 & 7 \\
\hline $1-2$ & 0.3 & 8 & 0.7 & 24 & 2.2 & 72 & 0.3 & 8 & 0.3 & 8 \\
\hline $1-3$ & 0.0 & 0 & 0.5 & 8 & 2.8 & 44 & 0.8 & 16 & 0.0 & 0 \\
\hline $1-4$ & 0.0 & 0 & 0.3 & 4 & 1.9 & 28 & 0.3 & 4 & 0.3 & 4 \\
\hline $1-5$ & 0.0 & 0 & 0.0 & 0 & 3.9 & 120 & 0.8 & 24 & 0.0 & 0 \\
\hline $2-1$ & 0.0 & 0 & 0.0 & 0 & 2.1 & 56 & 0.3 & 8 & 0.6 & 16 \\
\hline $2-2$ & 0.0 & 0 & 0.5 & 8 & 3.0 & 52 & 0.5 & 8 & 0.0 & 0 \\
\hline $2-3$ & 0.0 & 0 & 0.0 & 0 & 1.0 & 24 & 0.3 & 8 & 0.3 & 8 \\
\hline $2-4$ & 0.0 & 0 & 0.3 & 8 & 1.6 & 40 & 0.3 & 8 & 0.0 & 0 \\
\hline $2-5$ & 0.0 & 0 & 0.0 & 0 & 0.3 & 8 & 0.3 & 8 & 0.7 & 16 \\
\hline $3-1$ & 0.3 & 4 & 3.9 & 60 & 0.3 & 4 & 0.0 & 0 & 0.0 & 0 \\
\hline $3-2$ & 0.0 & 0 & 0.3 & 4 & 2.2 & 28 & 1.2 & 16 & 0.0 & 0 \\
\hline $3-3$ & 0.0 & 0 & 0.4 & 16 & 2.4 & 96 & 0.4 & 16 & 0.0 & 0 \\
\hline $3-4$ & 0.0 & 0 & 0.3 & 8 & 3.2 & 96 & 0.5 & 16 & 0.0 & 0 \\
\hline $3-5$ & 0.0 & 0 & 0.0 & 0 & 2.8 & 44 & 0.2 & 4 & 0.2 & 4 \\
\hline $4-1$ & 0.0 & 0 & 0.2 & 8 & 1.8 & 72 & 0.2 & 8 & 0.8 & 32 \\
\hline $4-2$ & 0.0 & 0 & 0.2 & 8 & 0.5 & 16 & 0.0 & 0 & 0.0 & 0 \\
\hline $4-3$ & 0.0 & 0 & 0.4 & 16 & 2.7 & 96 & 0.7 & 24 & 0.2 & 8 \\
\hline $4-4$ & 0.0 & 0 & 0.4 & 16 & 1.1 & 40 & 0.2 & 8 & 0.2 & 8 \\
\hline $4-5$ & 0.4 & 16 & 0.0 & 0 & 1.0 & 40 & 0.2 & 8 & 0.0 & 0 \\
\hline $5-1$ & 0.0 & 0 & 0.3 & 8 & 0.6 & 16 & 0.2 & 6 & 0.4 & 10 \\
\hline $5-2$ & 0.0 & 0 & 0.2 & 8 & 1.9 & 72 & 0.0 & 0 & 0.6 & 24 \\
\hline $5-3$ & 0.0 & 0 & 0.0 & 0 & 1.1 & 2 & 0.0 & 0 & 0.0 & 0 \\
\hline $5-4$ & 0.0 & 0 & 0.9 & 32 & 0.4 & 16 & 0.4 & 16 & 0.2 & 8 \\
\hline $5-5$ & 0.0 & 0 & 0.2 & 8 & 0.9 & 40 & 0.2 & 8 & 0.2 & 8 \\
\hline $6-1$ & 0.0 & 0 & 0.0 & 0 & 1.8 & 28 & 0.8 & 12 & 0.0 & 0 \\
\hline $6-2$ & 0.2 & 8 & 0.0 & 0 & 1.8 & 64 & 0.0 & 0 & 0.2 & 8 \\
\hline $6-3$ & 0.0 & 0 & 0.7 & 12 & 2.8 & 48 & 0.7 & 12 & 0.0 & 0 \\
\hline $6-4$ & 0.0 & 0 & 0.0 & 0 & 0.9 & 12 & 1.6 & 20 & 0.6 & 8 \\
\hline $6-5$ & 0.0 & 0 & 0.4 & 8 & 1.4 & 32 & 0.4 & 8 & 0.2 & 4 \\
\hline $7-1$ & 0.0 & 0 & 0.0 & 0 & 2.6 & 56 & 0.3 & 8 & 0.0 & 0 \\
\hline $7-2$ & 0.2 & 8 & 0.6 & 16 & 2.2 & 64 & 0.3 & 8 & 0.0 & 0 \\
\hline $7-3$ & 0.0 & 0 & 0.0 & 0 & 0.7 & 24 & 0.7 & 24 & 0.2 & 8 \\
\hline $7-4$ & 0.0 & 0 & 0.0 & 0 & 0.7 & 16 & 0.3 & 8 & 0.3 & 8 \\
\hline $7-5$ & 0.0 & 0 & 1.0 & 40 & 0.2 & 8 & 0.8 & 32 & 0.4 & 16 \\
\hline $8-1$ & 0.0 & 0 & 0.0 & 0 & 1.3 & 48 & 0.7 & 24 & 0.2 & 8 \\
\hline $8-2$ & 0.2 & 8 & 0.0 & 0 & 1.2 & 40 & 0.0 & 0 & 0.2 & 8 \\
\hline $8-3$ & 0.0 & 0 & 0.5 & 24 & 0.6 & 32 & 0.2 & 8 & 0.2 & 8 \\
\hline $8-4$ & 0.4 & 16 & 0.2 & 8 & 0.2 & 8 & 0.2 & 8 & 0.6 & 24 \\
\hline $8-5$ & 0.4 & 32 & 0.0 & 0 & 0.2 & 16 & 0.8 & 64 & 0.4 & 32 \\
\hline $9-1$ & 0.0 & 0 & 1.1 & 40 & 1.1 & 40 & 0.0 & 0 & 0.0 & 0 \\
\hline $9-2$ & 0.0 & 0 & 0.0 & 0 & 0.8 & 12 & 0.0 & 0 & 0.2 & 4 \\
\hline $9-3$ & 0.0 & 0 & 0.3 & 8 & 1.0 & 24 & 0.5 & 12 & 0.2 & 4 \\
\hline $9-4$ & 0.3 & 16 & 0.6 & 32 & 0.8 & 48 & 0.3 & 16 & 0.0 & 0 \\
\hline $9-5$ & 0.0 & 0 & 0.0 & 0 & 0.0 & 0 & 0.2 & 4 & 0.2 & 4 \\
\hline
\end{tabular}


Appendix 1.-Continued.

\begin{tabular}{|c|c|c|c|c|c|c|c|c|c|c|}
\hline \multirow[t]{2}{*}{ Samp le } & \multicolumn{2}{|c|}{$\frac{\text { UvIger Ina }}{s p}$} & \multicolumn{2}{|c|}{$\frac{\text { Florllus }}{\text { medlo-costatus }}$} & \multicolumn{2}{|c|}{$\frac{\text { Fissurina }}{\text { Iuclda }}$} & \multicolumn{2}{|c|}{$\begin{aligned} & \text { Lent IculIna sp } \\
&+ \text { MargInulInopsis } \\
&\end{aligned}$} & \multicolumn{2}{|c|}{$\frac{\text { Anoma I Inoides }}{? \mathrm{sp}}$} \\
\hline & $\%$ & no. & $\%$ & no. & $\%$ & no. & $\%$ & no. & $\%$ & no. \\
\hline$\overline{1-1}$ & 0.5 & 5 & 0.3 & 3 & 0.6 & 7 & 0.3 & 4 & 0.5 & 5 \\
\hline $1-2$ & 0.5 & 16 & 0.3 & 8 & 0.3 & 8 & 0.3 & 8 & 0.5 & 16 \\
\hline $1-3$ & 0.0 & 0 & 1.0 & 16 & 0.5 & 8 & 0.3 & 4 & 0.0 & 0 \\
\hline $1-4$ & 0.3 & 4 & 0.0 & 0 & 0.3 & 4 & 0.3 & 4 & 0.0 & 0 \\
\hline $1-5$ & 0.5 & 16 & 0.8 & 24 & 0.5 & 16 & 0.5 & 16 & 0.8 & 24 \\
\hline $2-1$ & 0.0 & 0 & 0.6 & 16 & 0.0 & 0 & 0.0 & 0 & 0.0 & 0 \\
\hline $2-2$ & 0.9 & 16 & 0.7 & 12 & 0.3 & 4 & 0.7 & 12 & 0.0 & 0 \\
\hline $2-3$ & 0.3 & 8 & 1.0 & 24 & 0.7 & 16 & 0.0 & 0 & 0.3 & 8 \\
\hline $2-4$ & 0.6 & 16 & 0.0 & 0 & 0.0 & 0 & 0.3 & 8 & 0.6 & 16 \\
\hline $2-5$ & 0.7 & 16 & 0.0 & 0 & 0.0 & 0 & 0.3 & 8 & 0.0 & 0 \\
\hline $3-1$ & 0.0 & 0 & 0.5 & 8 & 0.3 & 4 & 0.0 & 0 & 0.3 & 4 \\
\hline $3-2$ & 0.3 & 4 & 0.3 & 4 & 0.3 & 4 & 0.3 & 4 & 0.3 & 4 \\
\hline $3-3$ & 0.4 & 16 & 0.0 & 0 & 0.4 & 16 & 0.4 & 16 & 0.0 & 0 \\
\hline $3-4$ & 0.5 & 16 & 0.3 & 8 & 1.3 & 40 & 0.3 & 8 & 0.5 & 16 \\
\hline $3-5$ & 0.2 & 4 & 0.0 & 0 & 0.2 & 4 & 0.4 & 8 & 0.0 & 0 \\
\hline $4-1$ & 0.8 & 32 & 0.2 & 8 & 0.0 & 0 & 0.2 & 8 & 0.6 & 24 \\
\hline $4-2$ & 0.5 & 16 & 0.0 & 0 & 0.2 & 8 & 0.2 & 8 & 0.0 & 0 \\
\hline $4-3$ & 0.2 & 8 & 0.0 & 0 & 0.2 & 8 & 0.0 & 0 & 0.0 & 0 \\
\hline $4-4$ & 0.4 & 16 & 0.4 & 16 & 0.2 & 8 & 0.2 & 8 & 0.2 & 8 \\
\hline $4-5$ & 0.0 & 0 & 0.0 & 0 & 0.0 & 0 & 0.2 & 8 & 0.2 & 8 \\
\hline $5-1$ & 0.2 & 5 & 0.0 & 0 & 0.1 & 3 & 0.1 & 2 & 0.1 & 4 \\
\hline $5-2$ & 0.0 & 0 & 0.4 & 16 & 0.0 & 0 & 0.0 & 0 & 0.2 & 8 \\
\hline $5-3$ & 0.0 & 0 & 0.0 & 0 & 0.0 & 0 & 0.0 & 0 & 0.0 & 0 \\
\hline $5-4$ & 0.0 & 0 & 0.6 & 24 & 0.0 & 0 & 0.2 & 8 & 0.2 & 8 \\
\hline $5-5$ & 0.0 & 0 & 0.3 & 16 & 0.2 & 8 & 0.5 & 24 & 0.3 & 16 \\
\hline $6-1$ & 0.0 & 0 & 0.0 & 0 & 0.0 & 0 & 0.5 & 8 & 0.5 & 8 \\
\hline $6-2$ & 0.9 & 32 & 0.4 & 16 & 0.0 & 0 & 0.0 & 0 & 0.2 & 8 \\
\hline $6-3$ & 0.0 & 0 & 0.2 & 4 & 0.2 & 4 & 0.0 & 0 & 0.0 & 0 \\
\hline $6-4$ & 0.0 & 0 & 0.9 & 12 & 0.0 & 0 & 0.0 & 0 & 0.6 & 8 \\
\hline $6-5$ & 0.0 & 0 & 0.0 & 0 & 0.2 & 4 & 0.2 & 4 & 0.2 & 4 \\
\hline $7-1$ & 0.6 & 16 & 0.0 & 0 & 0.0 & 0 & 0.0 & 0 & 0.0 & 0 \\
\hline $7-2$ & 0.6 & 16 & 0.6 & 16 & 0.3 & 8 & 8.4 & 24 & 0.3 & 8 \\
\hline $7-3$ & 0.4 & 16 & 0.7 & 24 & 0.4 & 16 & 0.0 & 0 & 0.0 & 0 \\
\hline $7-4$ & 0.3 & 8 & 0.0 & 0 & 0.3 & 8 & 0.0 & 0 & 0.3 & 8 \\
\hline $7-5$ & 0.2 & 8 & 0.4 & 16 & 0.0 & 0 & 0.0 & 0 & 0.8 & 32 \\
\hline $8-1$ & 0.0 & 0 & 0.7 & 24 & 0.2 & 8 & 0.0 & 0 & 0.2 & 8 \\
\hline $8-2$ & 0.0 & 0 & 0.2 & 8 & 0.2 & 8 & 0.0 & 0 & 0.2 & 8 \\
\hline $8-3$ & 0.5 & 24 & 0.3 & 16 & 0.0 & 0 & 0.2 & 8 & 0.0 & 0 \\
\hline $8-4$ & 0.2 & 8 & 0.2 & 8 & 0.0 & 0 & 0.4 & 16 & 0.4 & 16 \\
\hline $8-5$ & 0.6 & 48 & 0.0 & 0 & 0.0 & 0 & 0.2 & 16 & 0.4 & 32 \\
\hline $9-1$ & 0.2 & 8 & 0.6 & 24 & 0.2 & 8 & 0.6 & 24 & 0.2 & 8 \\
\hline $9-2$ & 0.2 & 4 & 0.0 & 0 & 0.2 & 4 & 0.5 & 8 & 0.2 & 4 \\
\hline $9-3$ & 0.2 & 4 & 0.2 & 4 & 0.0 & 0 & 0.3 & 8 & 0.0 & 0 \\
\hline $9-4$ & 0.0 & 0 & 0.0 & 0 & 0.0 & 0 & 0.6 & 32 & 0.3 & 16 \\
\hline $9-5$ & 0.2 & 4 & 0.4 & 8 & 0.0 & 0 & 0.2 & 4 & 0.0 & 0 \\
\hline
\end{tabular}


Appendix 1.-Continued.

\begin{tabular}{|c|c|c|c|c|c|c|c|c|c|c|}
\hline \multirow[t]{2}{*}{ Samp } & \multicolumn{3}{|c|}{$\begin{array}{l}\text { Nonlon cf . Fu } \\
\text { N.Cassidulinoldes }\end{array}$} & $\frac{\text { Eursenkolna }}{\mathrm{s}}$ & \multicolumn{2}{|c|}{$\frac{\text { Lagena }}{\text { substrlata }}$} & \multicolumn{2}{|c|}{$\frac{\text { Qu Inque locul Ina }}{\mathrm{sp} \text {. }}$} & \multicolumn{2}{|c|}{ cf. Bullminella } \\
\hline & $\%$ & no. & $\%$ & no. & $\%$ & no. & $\%$ & no. & $\%$ & no. \\
\hline $1-1$ & 0.2 & 2 & 0.1 & 1 & 0.2 & 2 & 0.2 & 2 & 0.1 & 1 \\
\hline $1-2$ & 0.3 & 8 & 0.0 & 0 & 0.0 & 0 & 0.0 & 0 & 0.0 & 0 \\
\hline $1-3$ & 0.0 & 0 & 0.0 & 0 & 0.0 & 0 & 0.3 & 4 & 0.0 & 0 \\
\hline $1-4$ & 0.0 & 0 & 0.0 & 0 & 0.0 & 0 & 0.0 & 0 & 0.0 & 0 \\
\hline $1-5$ & 0.0 & 0 & 0.0 & 0 & 0.0 & 0 & 0.0 & 0 & 0.0 & 0 \\
\hline $2-1$ & 0.0 & 0 & 0.0 & 0 & 0.0 & 0 & 0.0 & 0 & 0.0 & 0 \\
\hline $2-2$ & 0.0 & 0 & 0.0 & 0 & 0.3 & 4 & 0.0 & 0 & 0.0 & 0 \\
\hline $2-3$ & 0.0 & 0 & 0.0 & 0 & 0.0 & 0 & 0.0 & 0 & 0.0 & 0 \\
\hline $2-4$ & 0.0 & 0 & 0.0 & 0 & 0.0 & 0 & 0.0 & 0 & 0.0 & 0 \\
\hline $2-5$ & 0.0 & 0 & 0.0 & 0 & 0.0 & 0 & 0.0 & 0 & 0.0 & 0 \\
\hline $3-1$ & 0.0 & 0 & 0.0 & 0 & 0.0 & 0 & 0.3 & 4 & 0.0 & 0 \\
\hline $3-2$ & 0.0 & 0 & 0.0 & 0 & 0.0 & 0 & 0.3 & 4 & 0.0 & 0 \\
\hline $3-3$ & 0.0 & 0 & 0.0 & 0 & 0.0 & 0 & 0.0 & 0 & 0.0 & 0 \\
\hline $3-4$ & 0.0 & 0 & 0.0 & 0 & 0.0 & 0 & 0.0 & 0 & 0.0 & 0 \\
\hline $3-5$ & 0.0 & 0 & 0.0 & 0 & 0.0 & 0 & 0.0 & 0 & 0.0 & 0 \\
\hline $4-1$ & 0.0 & 0 & 0.0 & 0 & 0.0 & 0 & 0.4 & 16 & 0.0 & 0 \\
\hline $4-2$ & 0.0 & 0 & 0.0 & 0 & 0.0 & 0 & 0.5 & 16 & 0.0 & 0 \\
\hline $4-3$ & 0.0 & 0 & 0.0 & 0 & 0.0 & 0 & 0.2 & 8 & 0.0 & 0 \\
\hline $4-4$ & 0.0 & 0 & 0.4 & 16 & 0.0 & 0 & 0.0 & 0 & 0.0 & 0 \\
\hline $4-5$ & 0.0 & 0 & 0.0 & 0 & 0.0 & 0 & 0.2 & 8 & 0.0 & 0 \\
\hline $5-1$ & 0.1 & 1 & 0.0 & 0 & 0.0 & 0 & 0.1 & 3 & 0.0 & 0 \\
\hline $5-2$ & 0.0 & 0 & 0.0 & 0 & 0.0 & 0 & 0.2 & 8 & 0.0 & 0 \\
\hline $5-3$ & 0.0 & 0 & 0.0 & 0 & 0.0 & 0 & 0.0 & 0 & 0.0 & 0 \\
\hline $5-4$ & 0.0 & 0 & 0.0 & 0 & 0.0 & 0 & 0.0 & 0 & 0.0 & 0 \\
\hline $5-5$ & 0.0 & 0 & 0.0 & 0 & 0.0 & 0 & 0.2 & 8 & 0.0 & 0 \\
\hline $6-1$ & 0.0 & 0 & 0.0 & 0 & 0.0 & 0 & 0.0 & 0 & 0.0 & 0 \\
\hline $6-2$ & 0.0 & 0 & 0.0 & 0 & 0.0 & 0 & 0.0 & 0 & 0.0 & 0 \\
\hline $6-3$ & 0.0 & 0 & 0.0 & 0 & 0.0 & 0 & 0.0 & 0 & 0.0 & 0 \\
\hline $6-4$ & 0.0 & 0 & 0.0 & 0 & 0.0 & 0 & 0.0 & 0 & 0.0 & 0 \\
\hline $6-5$ & 0.0 & 0 & 0.0 & 0 & 0.0 & 0 & 0.2 & 4 & 0.0 & 0 \\
\hline $7-1$ & 0.0 & 0 & 0.0 & 0 & 0.0 & 0 & 0.0 & 0 & 0.0 & 0 \\
\hline $7-2$ & 0.0 & 0 & 0.0 & 0 & 0.0 & 0 & 0.0 & 0 & 0.0 & 0 \\
\hline $7-3$ & 0.0 & 0 & 0.0 & 0 & 0.0 & 0 & 0.0 & 0 & 0.0 & 0 \\
\hline $7-4$ & 0.0 & 0 & 0.0 & 0 & 0.0 & 0 & 0.0 & 0 & 0.0 & 0 \\
\hline $7-5$ & 0.0 & 0 & 0.2 & 8 & 0.0 & 0 & 0.2 & 8 & 0.0 & 0 \\
\hline $8-1$ & 0.2 & 8 & 0.0 & 0 & 0.0 & 0 & 0.0 & 0 & 0.0 & 0 \\
\hline $8-2$ & 0.0 & 0 & 0.0 & 0 & 0.0 & 0 & 0.0 & 0 & 0.0 & 0 \\
\hline $8-3$ & 0.0 & 0 & 0.0 & 0 & 0.0 & 0 & 0.2 & 8 & 0.3 & 16 \\
\hline $8-4$ & 0.0 & 0 & 0.0 & 0 & 0.0 & 0 & 0.6 & 24 & 0.0 & 0 \\
\hline $8-5$ & 0.0 & 0 & 0.0 & 0 & 0.0 & 0 & 0.2 & 16 & 0.0 & 0 \\
\hline $9-1$ & 0.2 & 8 & 0.0 & 0 & 0.0 & 0 & 0.0 & 0 & 0.0 & 0 \\
\hline $9-2$ & 0.0 & 0 & 0.0 & 0 & 0.0 & 0 & 0.0 & 0 & 0.0 & 0 \\
\hline $9-3$ & 0.0 & 0 & 0.0 & 0 & 0.0 & 0 & 0.0 & 0 & 0.0 & 0 \\
\hline $9-4$ & 0.0 & 0 & 0.0 & 0 & 0.0 & 0 & 0.6 & 32 & 0.0 & 0 \\
\hline $9-5$ & 0.0 & 0 & 0.0 & 0 & 0.0 & 0 & 0.2 & 4 & 0.0 & 0 \\
\hline
\end{tabular}


Appendix 1.-Continued.

\begin{tabular}{|c|c|c|c|c|c|c|c|c|c|c|}
\hline \multirow[t]{2}{*}{ Sample } & \multicolumn{2}{|c|}{$\frac{\operatorname{Tr} \text { Ifar Ina }}{s p}$} & \multicolumn{2}{|c|}{$\frac{\text { Fissur ina }}{\text { bldens }}$} & \multicolumn{2}{|c|}{$\frac{\text { Discorbis }}{s p .}$} & \multicolumn{2}{|c|}{$\frac{\text { Lagena }}{\text { palmerae }}$} & \multicolumn{2}{|c|}{$\begin{array}{l}\text { Bolivina cf. } \\
\text { B. marginata }\end{array}$} \\
\hline & $\%$ & no. & $\%$ & no. & $\%$ & no. & $\mathscr{x}$ & no. & $\%$ & no. \\
\hline $1-1$ & 0.0 & 0 & 0.0 & 0 & 0.0 & 0 & 0.0 & 0 & 0.0 & 0 \\
\hline $1-2$ & 0.5 & 16 & 0.0 & 0 & 0.0 & 0 & 0.0 & 0 & 0.0 & 0 \\
\hline $1-3$ & 0.3 & 4 & 0.3 & 4 & 0.0 & 0 & 0.0 & 0 & 0.0 & 0 \\
\hline $1-4$ & 0.0 & 0 & 0.0 & 0 & 0.3 & 4 & 0.3 & 4 & 0.0 & 0 \\
\hline $1-5$ & 0.0 & 0 & 0.0 & 0 & 0.3 & 8 & 0.0 & 0 & 0.3 & 8 \\
\hline $2-1$ & 0.0 & 0 & 0.0 & 0 & 0.6 & 16 & 0.0 & 0 & 0.0 & 0 \\
\hline $2-2$ & 0.0 & 0 & 0.0 & 0 & 0.0 & 0 & 0.0 & 0 & 0.0 & 0 \\
\hline $2-3$ & 0.0 & 0 & 0.0 & 0 & 0.0 & 0 & 0.0 & 0 & 0.0 & 0 \\
\hline $2-4$ & 0.0 & 0 & 0.0 & 0 & 1.0 & 24 & 0.0 & 0 & 0.0 & 0 \\
\hline $2-5$ & 0.0 & 0 & 0.0 & 0 & 0.0 & 0 & 0.0 & 0 & 0.0 & 0 \\
\hline $3-1$ & 0.0 & 0 & 0.0 & 0 & 0.5 & 8 & 0.0 & 0 & 0.0 & 0 \\
\hline $3-2$ & 0.0 & 0 & 0.0 & 0 & 0.3 & 4 & 0.0 & 0 & 0.0 & 0 \\
\hline $3-3$ & 0.0 & 0 & 0.0 & 0 & 0.0 & 0 & 0.0 & 0 & 0.0 & 0 \\
\hline $3-4$ & 0.0 & 0 & 0.0 & 0 & 0.0 & 0 & 0.0 & 0 & 0.0 & 0 \\
\hline $3-5$ & 0.0 & 0 & 0.2 & 4 & 0.0 & 0 & 0.0 & 0 & 0.0 & 0 \\
\hline $4-1$ & 0.0 & 0 & 0.0 & 0 & 0.0 & 0 & 0.0 & 0 & 0.0 & 0 \\
\hline $4-2$ & 0.0 & 0 & 0.0 & 0 & 0.0 & 0 & 0.0 & 0 & 0.0 & 0 \\
\hline $4-3$ & 0.0 & 0 & 0.0 & 0 & 0.0 & 0 & 0.0 & 0 & 0.0 & 0 \\
\hline $4-4$ & 0.0 & 0 & 0.0 & 0 & 0.0 & 0 & 0.0 & 0 & 0.0 & 0 \\
\hline $4-5$ & 0.0 & 0 & 0.0 & 0 & 0.2 & 8 & 0.0 & 0 & 0.0 & 0 \\
\hline $5-1$ & 0.1 & 4 & 0.1 & 1 & 0.1 & 1 & 0.0 & 0 & 0.0 & 0 \\
\hline $5-2$ & 0.2 & 8 & 0.0 & 0 & 0.0 & 0 & 0.0 & 0 & 0.0 & 0 \\
\hline $5-3$ & 0.0 & 0 & 0.0 & 0 & 0.0 & 0 & 0.0 & 0 & 0.0 & 0 \\
\hline $5-4$ & 0.0 & 0 & 0.0 & 0 & 0.0 & 0 & 0.0 & 0 & 0.2 & 8 \\
\hline $5-5$ & 0.0 & 0 & 0.0 & 0 & 0.0 & 0 & 0.0 & 0 & 0.0 & 0 \\
\hline $6-1$ & 0.0 & 0 & 0.0 & 0 & 0.2 & 4 & 0.0 & 0 & 0.0 & 0 \\
\hline $6-2$ & 0.2 & 8 & 0.0 & 0 & 0.0 & 0 & 0.0 & 0 & 0.0 & 0 \\
\hline $6-3$ & 0.0 & 0 & 0.0 & 0 & 0.5 & 8 & 0.0 & 0 & 0.0 & 0 \\
\hline $6-4$ & 0.0 & 0 & 0.3 & 4 & 0.0 & 0 & 0.0 & 0 & 0.0 & 0 \\
\hline $6-5$ & 0.0 & 0 & 0.2 & 4 & 0.0 & 0 & 0.0 & 0 & 0.0 & 0 \\
\hline $7-1$ & 0.0 & 0 & 0.3 & 8 & 0.0 & 0 & 0.0 & 0 & 0.0 & 0 \\
\hline $7-2$ & 0.0 & 0 & 0.0 & 0 & 0.0 & 0 & 0.0 & 0 & 0.0 & 0 \\
\hline $7-3$ & 0.0 & 0 & 0.0 & 0 & 0.0 & 0 & 0.0 & 0 & 0.0 & 0 \\
\hline $7-4$ & 0.0 & 0 & 0.3 & 8 & 0.0 & 0 & 0.0 & 0 & 0.0 & 0 \\
\hline $7-5$ & 0.0 & 0 & 0.0 & 0 & 0.2 & 8 & 0.0 & 0 & 0.2 & 8 \\
\hline $8-1$ & 0.0 & 0 & 0.0 & 0 & 0.7 & 24 & 0.0 & 0 & 0.0 & 0 \\
\hline $8-2$ & 0.0 & 0 & 0.0 & 0 & 0.0 & 0 & 0.0 & 0 & 0.0 & 0 \\
\hline $8-3$ & 0.0 & 0 & 0.0 & 0 & 0.5 & 24 & 0.0 & 0 & 0.0 & 0 \\
\hline $8-4$ & 0.0 & 0 & 0.0 & 0 & 0.0 & 0 & 0.0 & 0 & 0.0 & 0 \\
\hline $8-5$ & 0.0 & 0 & 0.0 & 0 & 0.0 & 0 & 0.0 & 0 & 0.2 & 16 \\
\hline $9-1$ & 0.0 & 0 & 0.0 & 0 & 0.0 & 0 & 0.0 & 0 & 0.0 & 0 \\
\hline $9-2$ & 0.0 & 0 & 0.0 & 0 & 0.2 & 4 & 0.0 & 0 & 0.0 & 0 \\
\hline $9-3$ & 0.0 & 0 & 0.0 & 0 & 0.8 & 20 & 0.0 & 0 & 0.0 & 0 \\
\hline $9-4$ & 0.0 & 0 & 0.0 & 0 & 0.0 & 0 & 0.0 & 0 & 0.0 & 0 \\
\hline $9-5$ & 0.0 & 0 & 0.0 & 0 & 0.2 & 4 & 0.0 & 0 & 0.0 & 0 \\
\hline
\end{tabular}


Appendix 1.-Continued.

\begin{tabular}{|c|c|c|c|c|c|c|c|c|c|c|}
\hline \multirow[t]{2}{*}{ Sample } & \multicolumn{2}{|c|}{$\frac{\text { Dental Ina ? }}{\text { sp. }}$} & \multicolumn{2}{|c|}{$\begin{array}{l}\text { Lagena cf. } \\
\text { L. Iaevis }\end{array}$} & \multicolumn{2}{|c|}{$\frac{\text { Aster Iger inata }}{\mathrm{sp} .}$} & \multicolumn{2}{|c|}{$\frac{\text { Elphidium ? }}{\text { sp. }}$} & \multicolumn{2}{|c|}{$\frac{\text { Bolivina }}{\text { sp. }}$} \\
\hline & $\%$ & no. & $\%$ & no. & $\%$ & no. & $x$ & no. & \% & no. \\
\hline $1-1$ & 0.0 & 0 & 0.0 & 0 & 0.0 & 0 & 0.0 & 0 & 0.0 & 0 \\
\hline $1-2$ & 0.0 & 0 & 0.0 & 0 & 0.0 & 0 & 0.0 & 0 & 0.0 & 0 \\
\hline $1-3$ & 0.0 & 0 & 0.0 & 0 & 0.0 & 0 & 0.0 & 0 & 0.0 & 0 \\
\hline $1-4$ & 0.0 & 0 & 0.0 & 0 & 0.0 & 0 & 0.0 & 0 & 0.0 & 0 \\
\hline $1-5$ & 0.0 & 0 & 0.0 & 0 & 0.0 & 0 & 0.0 & 0 & 0.0 & 0 \\
\hline $2-1$ & 0.0 & 0 & 0.0 & 0 & 0.0 & 0 & 0.0 & 0 & 0.0 & 0 \\
\hline $2-2$ & 0.3 & 4 & 0.0 & 0 & 0.0 & 0 & 0.0 & 0 & 0.0 & 0 \\
\hline $2-3$ & 0.0 & 0 & 0.0 & 0 & 0.0 & 0 & 0.0 & 0 & 0.0 & 0 \\
\hline $2-4$ & 0.0 & 0 & 0.3 & 8 & 0.3 & 8 & 0.0 & 0 & 0.0 & 0 \\
\hline $2-5$ & 0.0 & 0 & 0.0 & 0 & 0.0 & 0 & 0.0 & 0 & 0.0 & 0 \\
\hline $3-1$ & 0.0 & 0 & 0.3 & 4 & 0.0 & 0 & 0.0 & 0 & 0.0 & 0 \\
\hline $3-2$ & 0.0 & 0 & 0.3 & 4 & 0.0 & 0 & 0.3 & 4 & 0.3 & 4 \\
\hline $3-3$ & 0.0 & 0 & 0.0 & 0 & 0.0 & 0 & 0.0 & 0 & 0.0 & 0 \\
\hline $3-4$ & 0.0 & 0 & 0.0 & 0 & 0.0 & 0 & 0.0 & 0 & 0.0 & 0 \\
\hline $3-5$ & 0.0 & 0 & 0.2 & 4 & 0.0 & 0 & 0.0 & 0 & 0.0 & 0 \\
\hline $4-1$ & 0.0 & 0 & 0.0 & 0 & 0.0 & 0 & 0.0 & 0 & 0.2 & 8 \\
\hline $4-2$ & 0.0 & 0 & 0.0 & 0 & 0.0 & 0 & 0.0 & 0 & 0.0 & 0 \\
\hline $4-3$ & 0.0 & 0 & 0.2 & 8 & 0.0 & 0 & 0.0 & 0 & 0.0 & 0 \\
\hline $4-4$ & 0.0 & 0 & 0.0 & 0 & 0.0 & 0 & 0.0 & 0 & 0.0 & 0 \\
\hline $4-5$ & 0.0 & 0 & 0.0 & 0 & 0.2 & 8 & 0.0 & 0 & 0.0 & 0 \\
\hline $5-1$ & 0.0 & 0 & 0.0 & 0 & 0.0 & 0 & 0.0 & 0 & 0.0 & 0 \\
\hline $5-2$ & 0.0 & 0 & 0.0 & 0 & 0.0 & 0 & 0.0 & 0 & 0.2 & 8 \\
\hline $5-3$ & 0.0 & 0 & 0.0 & 0 & 0.0 & 0 & 0.0 & 0 & 0.0 & 0 \\
\hline $5-4$ & 0.0 & 0 & 0.0 & 0 & 0.0 & 0 & 0.0 & 0 & 0.0 & 0 \\
\hline $5-5$ & 0.0 & 0 & 0.0 & 0 & 0.0 & 0 & 0.0 & 0 & 0.0 & 0 \\
\hline $6-1$ & 0.0 & 0 & 0.0 & 0 & 0.0 & 0 & 0.0 & 0 & 0.0 & 0 \\
\hline $6-2$ & 0.0 & 0 & 0.0 & 0 & 0.0 & 0 & 0.0 & 0 & 0.0 & 0 \\
\hline $6-3$ & 0.0 & 0 & 0.0 & 0 & 0.0 & 0 & 0.0 & 0 & 0.0 & 0 \\
\hline $6-4$ & 0.0 & 0 & 0.0 & 0 & 0.0 & 0 & 0.0 & 0 & 0.0 & 0 \\
\hline $6-5$ & 0.0 & 0 & 0.2 & 4 & 0.0 & 0 & 0.0 & 0 & 0.0 & 0 \\
\hline $7-1$ & 0.0 & 0 & 0.0 & 0 & 0.0 & 0 & 0.0 & 0 & 0.0 & 0 \\
\hline $7-2$ & 0.0 & 0 & 0.0 & 0 & 0.6 & 16 & 0.0 & 0 & 0.0 & 0 \\
\hline $7-3$ & 0.0 & 0 & 0.0 & 0 & 0.0 & 0 & 0.0 & 0 & 0.0 & 0 \\
\hline $7-4$ & 0.0 & 0 & 0.0 & 0 & 0.0 & 0 & 0.0 & 0 & 0.0 & 0 \\
\hline $7-5$ & 0.0 & 0 & 0.0 & 0 & 0.0 & 0 & 0.0 & 0 & 0.0 & 0 \\
\hline $8-1$ & 0.0 & 0 & 0.0 & 0 & 0.0 & 0 & 0.0 & 0 & 0.0 & 0 \\
\hline $8-2$ & 0.0 & 0 & 0.0 & 0 & 0.0 & 0 & 0.0 & 0 & 0.2 & 8 \\
\hline $8-3$ & 0.0 & 0 & 0.0 & 0 & 0.0 & 0 & 0.0 & 0 & 0.0 & 0 \\
\hline $8-4$ & 0.0 & 0 & 0.0 & 0 & 0.0 & 0 & 0.0 & 0 & 0.0 & 0 \\
\hline $8-5$ & 0.0 & 0 & 0.0 & 0 & 0.0 & 0 & 0.0 & 0 & 0.0 & 0 \\
\hline $9-1$ & 0.0 & 0 & 0.0 & 0 & 0.0 & 0 & 0.0 & 0 & 0.0 & 0 \\
\hline $9-2$ & 0.0 & 0 & 0.0 & 0 & 0.0 & 0 & 0.0 & 0 & 0.0 & 0 \\
\hline $9-3$ & 0.0 & 0 & 0.0 & 0 & 0.3 & 8 & 0.0 & 0 & 0.0 & 0 \\
\hline $9-4$ & 0.0 & 0 & 0.0 & 0 & 0.0 & 0 & 0.0 & 0 & 0.0 & 0 \\
\hline $9-5$ & 0.0 & 0 & 0.0 & 0 & 0.0 & 0 & 0.0 & 0 & 0.0 & 0 \\
\hline
\end{tabular}


Appendix 1.-Continued.

Sample Flssurlna cf. PseudopolymorphIna Buccella Florllus cf. Planularia F.marglnata sp. mansfle|d| F.grateloupl sp. \% no. \% no. $\%$ no. $\%$ no. $\%$ no.

$\begin{array}{lll}1-1 & 0.0 & 0 \\ 1-2 & 0.0 & 0 \\ 1-3 & 0.0 & 0 \\ 1-4 & 0.0 & 0 \\ 1-5 & 0.0 & 0 \\ 2-1 & 0.0 & 0 \\ 2-2 & 0.0 & 0 \\ 2-3 & 0.0 & 0 \\ 2-4 & 0.0 & 0 \\ 2-5 & 0.0 & 0 \\ 3-1 & 0.0 & 0 \\ 3-2 & 0.0 & 0 \\ 3-3 & 0.4 & 16 \\ 3-4 & 0.0 & 0 \\ 3-5 & 0.0 & 0 \\ 4-1 & 0.0 & 0 \\ 4-2 & 0.0 & 0 \\ 4-3 & 0.0 & 0 \\ 4-4 & 0.0 & 0 \\ 4-5 & 0.0 & 0 \\ 5-1 & 0.0 & 0 \\ 5-2 & 0.0 & 0 \\ 5-3 & 0.0 & 0 \\ 5-4 & 0.0 & 0 \\ 5-5 & 0.2 & 8 \\ 6-1 & 0.0 & 0 \\ 6-2 & 0.2 & 8 \\ 6-3 & 0.0 & 0 \\ 6-4 & 0.0 & 0 \\ 6-5 & 0.0 & 0 \\ 7-1 & 0.3 & 8 \\ 7-2 & 0.0 & 0 \\ 7-3 & 0.0 & 0 \\ 7-4 & 0.0 & 0 \\ 7-5 & 0.0 & 0 \\ 8-1 & 0.0 & 0 \\ 8-2 & 0.0 & 0 \\ 8-3 & 0.0 & 0 \\ 8-4 & 0.0 & 0 \\ 8-5 & 0.0 & 0 \\ 9-1 & 0.0 & 0 \\ 9-2 & 0.0 & 0 \\ 9-3 & 0.0 & 0 \\ 9-4 & 0.0 & 0 \\ 9-5 & 0.0 & 0 \\ & & \end{array}$

0.0

0.0

0.0

0.0

0.0

0.0

0.0

0.0

0.0

0.0

0.0

0.0

0.0

0.0

0.2

0.0

0.0

0.0

0.0

0.0

0.0

0.0

0.0

0.0

0.0

0.0

0.0

0.0

0.3

0.0

0.0

0.0

0.0

0.0

0.0

0.0

0.0

0.0

0.0

0.0

0.0

0.0

0.0

0.0

0.0
0.0

0.0

0.0

0.0

0.0

0.0

0.0

0.0

0.0

0.0

0.0

0.0

0.0

0.0

0.0

0.0

0.0

0.0

0.2

0.0

0.0

0.0

0.0

0.0

0.0

0.0

0.0

0.0

0.0

0.0

0.0

0.0

0.0

0.0

0.0

0.0

0.0

0.0

0.0

0.0

0.0

0.0

0.0

0.0

0.0
0.0

0.0

0.0

0.0

0.0

0.0

0.0

0.0

0.0

0.0

0.0

0.0

0.0

0.0

0.0

0.0

0.0

0.2

0.0

0.0

0.0

0.0

0.0

0.0

0.0

0.0

0.2

0.0

0.0

0.0

0.0

0.0

0.0

0.0

0.0

0.0

0.0

0.0

0.0

0.0

0.0

0.0

0.0

0.0

0.0

\section{0}

0

0

0

0

0

0

0

0

0

$$
0
$$

$$
0
$$

$$
0
$$

0

0

0

0

8

0
0

0

0

0

$$
0
$$

$$
0
$$

0
8

0

0

0

0

0

0
0

0

0

0

0

0

0

0

0

0

0
0

0
$0.0 \quad 0$

$0.0 \quad 0$

$0.0 \quad 0$

$0.0 \quad 0$

$0.0 \quad 0$

$0.0 \quad 0$

$0.0 \quad 0$

$0.0 \quad 0$

$0.0 \quad 0$

$0.0 \quad 0$

$0.0 \quad 0$

$0.0 \quad 0$

$0.0 \quad 0$

$0.0 \quad 0$

$0.0 \quad 0$

$0.0 \quad 0$

$0.0 \quad 0$

$0.0 \quad 0$

$0.0 \quad 0$

$0.0 \quad 0$

0.11

$0.0 \quad 0$

$0.0 \quad 0$

$0.0 \quad 0$

$0.0 \quad 0$

$0.0 \quad 0$

$0.0 \quad 0$

$0.0 \quad 0$

$0.0 \quad 0$

$0.0 \quad 0$

$0.0 \quad 0$

$0.0 \quad 0$

$0.0 \quad 0$

$0.0 \quad 0$

$0.0 \quad 0$

$0.0 \quad 0$

$0.0 \quad 0$

$0.0 \quad 0$

$0.0 \quad 0$

$0.0 \quad 0$

$0.0 \quad 0$

$0.0 \quad 0$

$0.0 \quad 0$

$0.0 \quad 0$ 
Appendix 1.-Continued.

\begin{tabular}{|c|c|c|c|c|c|c|c|c|c|c|}
\hline \multicolumn{3}{|c|}{ Samp le Ammon Ia } & \multicolumn{2}{|c|}{$\frac{\text { Sp I rop lectamm Ina }}{s p .}$} & \multicolumn{2}{|c|}{$\frac{\text { BullmInella cf. }}{\text { B.subfus Iform Is }}$} & \multicolumn{2}{|c|}{$\begin{array}{l}\text { Neoconorbina } \\
\text { terquem I }\end{array}$} & \multicolumn{2}{|c|}{$\frac{\text { Qu Inque loc }}{\text { ulina cf.Q }}$} \\
\hline & $\%$ & no. & $\%$ & no. & $\%$ & no. & $\%$ & no. & $\%$ & no. \\
\hline $1-1$ & 0.0 & 0 & 0.0 & 0 & 0.0 & 0 & 0.0 & 0 & 0.0 & 0 \\
\hline $1-2$ & 0.0 & 0 & 0.0 & 0 & 0.0 & 0 & 0.0 & 0 & 0.0 & 0 \\
\hline $1-3$ & 0.0 & 0 & 0.0 & 0 & 0.0 & 0 & 0.0 & 0 & 0.0 & 0 \\
\hline $1-4$ & 0.0 & 0 & 0.0 & 0 & 0.0 & 0 & 0.0 & 0 & 0.0 & 0 \\
\hline $1-5$ & 0.0 & 0 & 0.0 & 0 & 0.0 & 0 & 0.0 & 0 & 0.0 & 0 \\
\hline $2-1$ & 0.0 & 0 & 0.0 & 0 & 0.0 & 0 & 0.0 & 0 & 0.0 & 0 \\
\hline $2-2$ & 0.0 & 0 & 0.0 & 0 & 0.0 & 0 & 0.0 & 0 & 0.0 & 0 \\
\hline $2-3$ & 0.0 & 0 & 0.0 & 0 & 0.0 & 0 & 0.0 & 0 & 0.0 & 0 \\
\hline $2-4$ & 0.0 & 0 & 0.0 & 0 & 0.0 & 0 & 0.0 & 0 & 0.0 & 0 \\
\hline $2-5$ & 0.0 & 0 & 0.0 & 0 & 0.0 & 0 & 0.0 & 0 & 0.0 & 0 \\
\hline $3-1$ & 0.0 & 0 & 0.0 & 0 & 0.0 & 0 & 0.0 & 0 & 0.0 & 0 \\
\hline $3-2$ & 0.0 & 0 & 0.0 & 0 & 0.0 & 0 & 0.0 & 0 & 0.0 & 0 \\
\hline $3-3$ & 0.0 & 0 & 0.0 & 0 & 0.0 & 0 & 0.0 & 0 & 0.4 & 16 \\
\hline $3-4$ & 0.0 & 0 & 0.0 & 0 & 0.0 & 0 & 0.0 & 0 & 0.0 & 0 \\
\hline $3-5$ & 0.0 & 0 & 0.0 & 0 & 0.0 & 0 & 0.0 & 0 & 0.0 & 0 \\
\hline $4-1$ & 0.0 & 0 & 0.0 & 0 & 0.0 & 0 & 0.0 & 0 & 0.0 & 0 \\
\hline $4-2$ & 0.0 & 0 & 0.0 & 0 & 0.0 & 0 & 0.0 & 0 & 0.0 & 0 \\
\hline $4-3$ & 0.0 & 0 & 0.0 & 0 & 0.0 & 0 & 0.0 & 0 & 0.0 & 0 \\
\hline $4-4$ & 0.0 & 0 & 0.0 & 0 & 0.0 & 0 & 0.0 & 0 & 0.0 & 0 \\
\hline $4-5$ & 0.0 & 0 & 0.0 & 0 & 0.0 & 0 & 0.0 & 0 & 0.0 & 0 \\
\hline $5-1$ & 0.1 & 1 & 0.0 & 0 & 0.0 & 0 & 0.0 & 0 & 0.0 & 0 \\
\hline $5-2$ & 0.0 & 0 & 0.0 & 0 & 0.0 & 0 & 0.0 & 0 & 0.0 & 0 \\
\hline $5-3$ & 1.1 & 2 & 0.0 & 0 & 0.0 & 0 & 0.0 & 0 & 0.0 & 0 \\
\hline $5-4$ & 0.0 & 0 & 0.0 & 0 & 0.0 & 0 & 0.0 & 0 & 0.0 & 0 \\
\hline $5-5$ & 0.0 & 0 & 0.0 & 0 & 0.0 & 0 & 0.0 & 0 & 0.0 & 0 \\
\hline $6-1$ & 0.0 & 0 & 0.0 & 0 & 0.0 & 0 & 0.0 & 0 & 0.0 & 0 \\
\hline $6-2$ & 0.0 & 0 & 0.0 & 0 & 0.0 & 0 & 0.0 & 0 & 0.0 & 0 \\
\hline $6-3$ & 0.0 & 0 & 0.0 & 0 & 0.0 & 0 & 0.0 & 0 & 0.0 & 0 \\
\hline $6-4$ & 0.0 & 0 & 0.0 & 0 & 0.0 & 0 & 0.0 & 0 & 0.0 & 0 \\
\hline $6-5$ & 0.0 & 0 & 0.0 & 0 & 0.0 & 0 & 0.0 & 0 & 0.0 & 0 \\
\hline $7-1$ & 0.0 & 0 & 0.0 & 0 & 0.0 & 0 & 0.0 & 0 & 0.0 & 0 \\
\hline $7-2$ & 0.0 & 0 & 0.0 & 0 & 0.0 & 0 & 0.0 & 0 & 0.0 & 0 \\
\hline $7-3$ & 0.0 & 0 & 0.0 & 0 & 0.0 & 0 & 0.0 & 0 & 0.0 & 0 \\
\hline $7-4$ & 0.0 & 0 & 0.0 & 0 & 0.0 & 0 & 0.0 & 0 & 0.0 & 0 \\
\hline $7-5$ & 0.0 & 0 & 0.2 & 8 & 0.0 & 0 & 0.0 & 0 & 0.0 & 0 \\
\hline $8-1$ & 0.0 & 0 & 0.0 & 0 & 0.0 & 0 & 0.0 & 0 & 0.0 & 0 \\
\hline $8-2$ & 0.0 & 0 & 0.0 & 0 & 0.0 & 0 & 0.0 & 0 & 0.0 & 0 \\
\hline $8-3$ & 0.0 & 0 & 0.0 & 0 & 0.0 & 0 & 0.0 & 0 & 0.0 & 0 \\
\hline $8-4$ & 0.0 & 0 & 0.0 & 0 & 0.0 & 0 & 0.0 & 0 & 0.0 & 0 \\
\hline $8-5$ & 0.0 & 0 & 0.0 & 0 & 0.0 & 0 & 0.0 & 0 & 0.0 & 0 \\
\hline $9-1$ & 0.0 & 0 & 0.0 & 0 & 0.2 & 8 & 0.0 & 0 & 0.0 & 0 \\
\hline $9-2$ & 0.0 & 0 & 0.0 & 0 & 0.0 & 0 & 0.0 & 0 & 0.0 & 0 \\
\hline $9-3$ & 0.0 & 0 & 0.0 & 0 & 0.0 & 0 & 0.0 & 0 & 0.0 & 0 \\
\hline $9-4$ & 0.0 & 0 & 0.3 & 16 & 0.0 & 0 & 0.3 & 16 & 0.0 & 0 \\
\hline $9-5$ & 0.0 & 0 & 0.0 & 0 & 0.0 & 0 & 0.0 & 0 & 0.0 & 0 \\
\hline
\end{tabular}


Appendix 1.-Continued.

\begin{tabular}{|c|c|c|c|c|c|c|c|}
\hline \multirow[t]{2}{*}{ Samp Ie } & \multirow{2}{*}{$\begin{array}{l}\text { Total " } \\
\text { specimens }\end{array}$} & \multirow[t]{2}{*}{ Split $s \mid z \theta$} & \multirow[t]{2}{*}{ - specles } & \multirow[t]{2}{*}{$H(s)$} & \multirow[t]{2}{*}{$E$} & \multicolumn{2}{|c|}{ Planktonics } \\
\hline & & & & & & $\%$ & no. \\
\hline $1-1$ & 1180 & a I l & 25 & 1.97 & .28 & 0.3 & 4 \\
\hline $1-2$ & 3248 & $1 / 8$ & 20 & 1.96 & .37 & 0.0 & 0 \\
\hline $1-3$ & 1548 & $1 / 4$ & 18 & 1.90 & .35 & 0.0 & 0 \\
\hline $1-4$ & 1348 & $1 / 4$ & 18 & 1.80 & .34 & 0.0 & 0 \\
\hline $1-5$ & 3112 & $1 / 8$ & 18 & 2.00 & .41 & 0.0 & 0 \\
\hline $2-1$ & 2656 & $1 / 8$ & 14 & 1.86 & .46 & 0.3 & 1 \\
\hline $2-2$ & 1756 & $1 / 4$ & 18 & 1.92 & .38 & 0.2 & 1 \\
\hline $2-3$ & 2352 & $1 / 8$ & 16 & 1.80 & .38 & 0.0 & 0 \\
\hline $2-4$ & 2440 & $1 / 8$ & 17 & 1.81 & .36 & 0.0 & 0 \\
\hline $2-5$ & 2392 & $1 / 8$ & 14 & 1.63 & .37 & 0.3 & 1 \\
\hline $3-1$ & 1548 & $1 / 4$ & 18 & 1.95 & .39 & 0.5 & 2 \\
\hline $3-2$ & 1300 & $1 / 4$ & 23 & 1.95 & .30 & 0.3 & 1 \\
\hline $3-3$ & 4016 & $1 / 16$ & 17 & 1.90 & .39 & 0.0 & 0 \\
\hline $3-4$ & 3000 & $1 / 8$ & 17 & 2.03 & .45 & 0.0 & 0 \\
\hline $3-5$ & 1616 & $1 / 4$ & 18 & 1.96 & .40 & 0.5 & 2 \\
\hline $4-1$ & 3920 & $1 / 8$ & 19 & 1.86 & .34 & 0.6 & 3 \\
\hline $4-2$ & 3232 & $1 / 8$ & 15 & 1.60 & .33 & 0.0 & 0 \\
\hline $4-3$ & 3576 & $1 / 8$ & 19 & 1.66 & .28 & 0.7 & 3 \\
\hline $4-4$ & 3680 & $1 / 8$ & 20 & 1.84 & .31 & 0.4 & 2 \\
\hline $4-5$ & 4104 & $1 / 8$ & 18 & 1.58 & .27 & 0.2 & 1 \\
\hline $5-1$ & 2793 & all & 24 & 1.40 & .17 & 0.2 & 5 \\
\hline $5-2$ & 3728 & $1 / 8$ & 17 & 1.61 & .29 & 0.4 & 2 \\
\hline $5-3$ & 178 & all & 9 & 1.48 & .49 & 0.6 & 1 \\
\hline $5-4$ & 3672 & $1 / 8$ & 18 & 1.65 & .29 & 0.0 & 0 \\
\hline $5-5$ & 4584 & $1 / 8$ & 20 & 1.82 & .31 & 0.2 & 1 \\
\hline $6-1$ & 1592 & $1 / 4$ & 14 & 1.29 & .26 & 0.0 & 0 \\
\hline $6-2$ & 3464 & $1 / 8$ & 18 & 1.90 & .37 & 0.2 & 1 \\
\hline $6-3$ & 1684 & $1 / 4$ & 15 & 1.69 & .36 & 0.2 & 1 \\
\hline $6-4$ & 1264 & $1 / 4$ & 16 & 1.91 & .42 & 0.0 & 0 \\
\hline $6-5$ & 2252 & $1 / 4$ & 19 & 1.78 & .31 & 0.0 & 0 \\
\hline $7-1$ & 2752 & $1 / 8$ & 14 & 1.57 & .34 & 0.0 & 0 \\
\hline $7-2$ & 2848 & $1 / 8$ & 19 & 1.89 & .35 & 0.0 & 0 \\
\hline $7-3$ & 3544 & $1 / 8$ & 15 & 1.75 & .38 & 0.0 & 0 \\
\hline $7-4$ & 2384 & $1 / 8$ & 16 & 1.83 & .39 & 0.0 & 0 \\
\hline $7-5$ & 4064 & $1 / 8$ & 21 & 1.86 & .31 & 0.0 & 0 \\
\hline $8-1$ & 3600 & $1 / 8$ & 17 & 1.64 & .30 & 0.0 & 0 \\
\hline $8-2$ & 3256 & $1 / 8$ & 16 & 1.67 & .33 & 0.0 & 0 \\
\hline $8-3$ & 5072 & $1 / 8$ & 18 & 1.61 & .28 & 0.5 & 3 \\
\hline $8-4$ & 4088 & $1 / 8$ & 20 & 1.49 & .22 & 0.2 & 1 \\
\hline $8-5$ & 7600 & $1 / 16$ & 18 & 1.62 & .28 & 0.2 & 1 \\
\hline $9-1$ & 3736 & $1 / 8$ & 18 & 1.85 & .35 & 0.6 & 3 \\
\hline $9-2$ & 1724 & $1 / 4$ & 16 & 1.82 & .38 & 0.2 & 1 \\
\hline $9-3$ & 2420 & $1 / 4$ & 16 & 1.81 & .38 & 0.3 & 2 \\
\hline $9-4$ & 6032 & $1 / 16$ & 17 & 1.82 & .36 & 0.5 & 2 \\
\hline $9-5$ & 1888 & $1 / 4$ & 14 & 1.58 & .35 & 0.0 & 0 \\
\hline
\end{tabular}




\section{Appendix 2}

\section{Bed 18, Calvert Cliffs, Maryland}

\begin{tabular}{|c|c|c|c|c|c|}
\hline Samp I $\theta$ & $\frac{\text { Textularla }}{\text { sp. }}$ & $\frac{\text { Elph } \mid \text { d I um }}{\text { maryland } \text { cum }}$ & $\frac{\text { Valvul Inar Ia }}{\text { flor Idana }}$ & $\frac{\text { Buccel Ia }}{\operatorname{mansf|e|d|}}$ & $\frac{\text { clblcldes }}{\text { lobatu|us }}$ \\
\hline
\end{tabular}

\begin{tabular}{|c|c|c|c|c|c|c|c|c|c|c|}
\hline$A-1$ & 2.5 & 16 & 0.6 & 4 & 3.8 & 24 & 6.9 & 44 & 4.1 & 26 \\
\hline$A-2$ & 3.4 & 21 & 1.6 & 10 & 5.7 & 35 & 2.6 & 16 & 4.6 & 28 \\
\hline$A-3$ & 2.0 & 26 & 0.3 & 4 & 2.6 & 34 & 2.6 & 34 & 2.7 & 36 \\
\hline$A-4$ & 1.0 & 8 & 0.0 & 0 & 3.2 & 26 & 2.0 & 16 & 6.0 & 48 \\
\hline$A-5$ & 4.8 & 48 & 0.6 & 6 & 5.8 & 58 & 3.2 & 32 & 4.4 & 44 \\
\hline$B-1$ & 0.9 & 12 & 0.6 & 6 & 3.3 & 36 & 2.5 & 28 & 3.1 & 34 \\
\hline$B-2$ & 5.0 & 21 & 1.9 & 8 & 2.4 & 10 & 6.6 & 28 & 4.0 & 17 \\
\hline$B-3$ & 4.4 & 14 & 2.2 & 7 & 3.8 & 12 & 7.6 & 24 & 3.5 & 11 \\
\hline$B-4$ & 5.2 & 34 & 0.6 & 4 & 4.3 & 28 & 4.0 & 26 & 7.7 & 50 \\
\hline$B-5$ & 2.4 & 18 & 1.3 & 10 & 3.7 & 28 & 4.5 & 34 & 3.4 & 26 \\
\hline$C-1$ & 2.4 & 32 & 0.7 & 10 & 1.9 & 26 & 2.4 & 32 & 3.7 & 50 \\
\hline$C-2$ & 2.5 & 28 & 0.8 & 9 & 3.2 & 36 & 2.4 & 27 & 3.6 & 40 \\
\hline$c-3$ & 3.7 & 24 & 1.6 & 10 & 3.1 & 20 & 3.7 & 24 & 5.6 & 36 \\
\hline$C-4$ & 3.3 & 28 & 1.4 & 12 & 1.9 & 16 & 2.6 & 22 & 2.4 & 20 \\
\hline$C-5$ & 5.9 & 32 & 1.8 & 10 & 3.7 & 20 & 4.2 & 23 & 4.8 & 26 \\
\hline$D-1$ & 4.3 & 6 & 2.9 & 4 & 2.9 & 4 & 15.2 & 21 & 4.3 & 6 \\
\hline$D-2$ & 3.9 & 14 & 0.8 & 3 & 6.5 & 23 & 7.9 & 28 & 5.1 & 18 \\
\hline$D-3$ & 0.9 & 3 & 0.0 & 0 & 4.0 & 14 & 2.6 & 9 & 3.2 & 11 \\
\hline$D-4$ & 7.8 & 46 & 0.7 & 4 & 4.1 & 24 & 5.1 & 30 & 8.1 & 48 \\
\hline$D-5$ & 4.2 & 36 & 0.7 & 6 & 4.2 & 36 & 3.5 & 30 & 4.0 & 34 \\
\hline$E-1$ & 4.7 & 21 & 2.6 & 12 & 6.8 & 31 & 2.6 & 12 & 6.2 & 28 \\
\hline$E-2$ & 4.5 & 21 & 1.4 & 7 & 5.1 & 24 & 5.9 & 28 & 3.9 & 19 \\
\hline$E-3$ & 2.1 & 26 & 0.8 & 10 & 5.6 & 70 & 3.7 & 46 & 1.7 & 22 \\
\hline$E-4$ & 5.3 & 50 & 0.4 & 4 & 3.6 & 34 & 4.0 & 38 & 2.8 & 26 \\
\hline$E-5$ & 2.2 & 22 & 0.6 & 6 & 4.8 & 48 & 4.6 & 46 & 5.0 & 50 \\
\hline$F-1$ & 2.5 & 38 & 0.4 & 6 & 3.0 & 46 & 1.9 & 30 & 3.6 & 56 \\
\hline$F-2$ & 4.8 & 54 & 0.4 & 4 & 4.6 & 52 & 2.5 & 28 & 4.1 & 46 \\
\hline$F-3$ & 4.3 & 40 & 1.1 & 10 & 4.3 & 40 & 2.1 & 20 & 2.8 & 26 \\
\hline$F-4$ & 0.7 & 10 & $1: 6$ & 22 & 3.8 & 52 & 3.4 & 46 & 4.9 & 66 \\
\hline$F-5$ & 4.1 & 27 & 0.6 & 4 & 4.3 & 28 & 5.1 & 33 & 3.0 & 20 \\
\hline G-1 & 5.5 & 33 & 1.8 & 11 & 3.8 & 23 & 3.3 & 20 & 5.3 & 32 \\
\hline G-2 & 8.5 & 27 & 2.5 & 8 & 6.6 & 21 & 4.4 & 14 & 6.9 & 22 \\
\hline G-3 & 5.1 & 12 & 2.1 & 5 & 7.2 & 17 & 5.5 & 13 & 5.9 & 14 \\
\hline G-4 & 2.2 & 18 & 0.5 & 4 & 3.2 & 26 & 4.1 & 34 & 3.2 & 26 \\
\hline G-5 & 4.9 & 44 & 0.9 & 8 & 4.2 & 38 & 3.3 & 30 & 2.7 & 24 \\
\hline $\mathrm{H}-1$ & 6.7 & 21 & 2.6 & 8 & 8.0 & 25 & 6.1 & 19 & 8.3 & 26 \\
\hline $\mathrm{H}-2$ & 2.0 & 26 & 0.3 & 4 & 2.4 & 32 & 3.0 & 40 & 3.8 & 50 \\
\hline $\mathrm{H}-3$ & 3.3 & 36 & 1.1 & 12 & 3.5 & 38 & 3.7 & 40 & 5.0 & 54 \\
\hline $\mathrm{H}-4$ & 1.8 & 16 & 2.3 & 20 & 4.6 & 40 & 4.6 & 40 & 5.7 & 50 \\
\hline $\mathrm{H}-5$ & 4.8 & 18 & 1.1 & 4 & 5.0 & 19 & 6.1 & 23 & 5.6 & 21 \\
\hline $1-1$ & 1.2 & 10 & 0.7 & 6 & 5.1 & 42 & 2.6 & 22 & 4.3 & 36 \\
\hline $1-2$ & 3.2 & 40 & 0.8 & 10 & 4.3 & 54 & 1.7 & 22 & 3.0 & 38 \\
\hline $1-3$ & 7.7 & 20 & 2.3 & 6 & 6.9 & 18 & 10.3 & 27 & 6.5 & 17 \\
\hline $1-4$ & 3.3 & 24 & 0.5 & 4 & 5.8 & 42 & 3.6 & 26 & 3.9 & 28 \\
\hline $1-5$ & 4.6 & 21 & 1.7 & 8 & 4.6 & 21 & 4.9 & 23 & 4.6 & 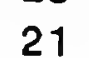 \\
\hline
\end{tabular}


Appendix 2.-Continued.

\begin{tabular}{|c|c|c|c|c|c|c|c|c|c|c|}
\hline \multirow[t]{2}{*}{ Samp Ie } & \multicolumn{2}{|c|}{$\frac{\text { DIscorbls }}{\text { basslerl }}$} & \multicolumn{2}{|c|}{ Discorbis } & \multicolumn{2}{|c|}{$\begin{array}{l}\text { Rosalina cf. } \\
\text { R. globularis }\end{array}$} & \multicolumn{2}{|c|}{$\frac{\text { Ep Istom Inel Ia }}{\text { ponton I }}$} & \multicolumn{2}{|c|}{$\frac{\text { Bolivina }}{\text { Daula }}$} \\
\hline & & no. & & no. & $\%$ & no. & $\%$ & no. & $\overline{\%}$ & no. \\
\hline$A-1$ & 3.1 & 20 & 0.9 & 6 & 0.0 & 0 & 0.6 & 4 & 30.2 & 192 \\
\hline$A-2$ & 3.1 & 19 & 0.0 & 0 & 0.6 & 4 & 1.0 & 6 & 39.1 & 239 \\
\hline$A-3$ & 1.7 & 22 & 0.2 & 2 & 0.2 & 2 & 0.8 & 10 & 34.3 & 452 \\
\hline$A-4$ & 2.5 & 20 & 0.0 & 0 & 0.2 & 2 & 1.5 & 12 & 39.5 & 318 \\
\hline$A-5$ & 2.6 & 26 & 0.0 & 0 & 0.2 & 2 & 0.2 & 2 & 34.4 & 342 \\
\hline$B-1$ & 2.7 & 30 & 0.4 & 4 & 0.0 & 0 & 0.5 & 6 & 32.7 & 358 \\
\hline$B-2$ & 3.3 & 14 & 3.3 & 14 & 0.2 & 1 & 0.7 & 3 & 25.4 & 107 \\
\hline$B-3$ & 0.0 & 0 & 15.2 & 48 & 0.0 & 0 & 2.2 & 7 & 20.0 & 63 \\
\hline$B-4$ & 2.5 & 16 & 1.8 & 12 & 0.9 & 6 & 0.3 & 2 & 38.7 & 252 \\
\hline$B-5$ & 1.6 & 12 & 0.0 & 0 & 0.5 & 4 & 0.3 & 2 & 30.6 & 232 \\
\hline$c-1$ & 2.2 & 30 & 0.2 & 2 & 0.2 & 2 & 0.7 & 10 & 35.6 & 478 \\
\hline$C-2$ & 2.4 & 26 & 0.1 & 1 & 0.4 & 4 & 0.6 & 7 & 32.1 & 354 \\
\hline$C-3$ & 2.5 & 12 & 0.3 & 2 & 0.0 & 0 & 1.6 & 10 & 32.2 & 206 \\
\hline$C-4$ & 2.4 & 20 & 0.2 & 2 & 0.5 & 4 & 1.4 & 12 & 30.9 & 260 \\
\hline$C-5$ & 3.7 & 20 & 1.3 & 7 & 0.2 & 1 & 0.0 & 0 & 28.8 & 157 \\
\hline$D-1$ & 1.4 & 2 & 0.0 & 0 & 2.2 & 3 & 0.0 & 0 & 27.5 & 38 \\
\hline$D-2$ & 1.1 & 4 & 0.0 & 0 & 1.1 & 4 & 0.3 & 1 & 38.0 & 135 \\
\hline$D-3$ & 2.3 & 8 & 0.0 & 0 & 0.3 & 1 & 0.3 & 1 & 39.7 & 138 \\
\hline$D-4$ & 2.7 & 16 & 0.0 & 0 & 1.4 & 8 & 1.4 & 8 & 27.1 & 160 \\
\hline$D-5$ & 2.8 & 24 & 0.0 & 0 & 0.7 & 6 & 1.4 & 12 & 33.1 & 280 \\
\hline$E-1$ & 2.3 & 11 & 2.6 & 12 & 0.3 & 1 & 1.2 & 5 & 29.7 & 135 \\
\hline$E-2$ & 0.6 & 3 & 0.0 & 0 & 1.1 & 5 & 0.6 & 3 & 37.4 & 177 \\
\hline$E-3$ & 1.9 & 24 & 0.3 & 4 & 0.2 & 2 & 0.8 & 10 & 38.6 & 484 \\
\hline$E-4$ & 3.2 & 30 & 0.4 & 4 & 0.2 & 2 & 1.1 & 10 & 33.8 & 318 \\
\hline$E-5$ & 1.6 & 16 & 0.2 & 2 & 0.4 & 4 & 1.4 & 14 & 35.6 & 354 \\
\hline$F-1$ & 1.2 & 18 & 0.0 & 0 & 0.1 & 2 & 1.3 & 20 & 35.7 & 550 \\
\hline$F-2$ & 1.6 & 18 & 0.2 & 2 & 0.5 & 6 & 0.9 & 10 & 34.9 & 392 \\
\hline$F-3$ & 1.7 & 16 & 0.0 & 0 & 0.6 & 6 & 1.1 & 10 & 31.1 & 290 \\
\hline$F-4$ & 1.0 & 14 & 0.0 & 0 & 1.2 & 16 & 1.5 & 20 & 38.9 & 528 \\
\hline$F-5$ & 2.1 & 13 & 0.6 & 4 & 0.2 & 1 & 1.0 & 7 & 29.5 & 191 \\
\hline$G-1$ & 1.5 & 9 & 0.4 & 3 & 0.9 & 5 & 0.2 & 1 & 35.7 & 215 \\
\hline G-2 & 0.6 & 2 & 0.0 & 0 & 1.3 & 4 & 0.6 & 2 & 29.2 & 93 \\
\hline G-3 & 3.4 & 8 & 2.1 & 5 & 0.4 & 1 & 0.4 & 1 & 31.6 & 75 \\
\hline$G-4$ & 4.4 & 36 & 4.1 & 34 & 0.0 & 0 & 0.0 & 0 & 32.0 & 264 \\
\hline G-5 & 1.6 & 14 & 0.2 & 2 & 0.7 & 6 & 1.3 & 12 & 32.4 & 290 \\
\hline$H-1$ & 3.5 & 11 & 0.6 & 2 & 0.6 & 2 & 0.3 & 1 & 30.7 & 96 \\
\hline$H-2$ & 1.0 & 14 & 0.3 & 4 & 0.3 & 4 & 1.0 & 14 & 35.3 & 470 \\
\hline $\mathrm{H}-3$ & 2.4 & 26 & 0.0 & 0 & 0.7 & 8 & 0.7 & 8 & 33.9 & 366 \\
\hline$H-4$ & 0.5 & 4 & 0.5 & 4 & 0.2 & 2 & 0.5 & 4 & 30.8 & 270 \\
\hline $\mathrm{H}-5$ & 2.1 & 8 & 0.8 & 3 & 0.8 & 3 & 0.3 & 1 & 29.7 & 112 \\
\hline$i-1$ & 0.5 & 4 & 0.5 & 4 & 0.5 & 4 & 0.5 & 4 & 47.0 & 390 \\
\hline$I-2$ & 1.3 & 16 & 0.0 & 0 & 0.6 & 8 & 0.9 & 12 & 42.4 & 534 \\
\hline $1-3$ & 1.1 & 3 & 1.1 & 3 & 3.4 & 9 & 0.8 & 2 & 23.0 & 60 \\
\hline $1-4$ & 1.1 & 8 & 0.0 & 0 & 1.9 & 14 & 0.5 & 4 & 34.8 & 252 \\
\hline $1-5$ & 3.2 & 15 & 0.3 & 1 & 0.9 & 4 & 0.6 & 3 & 36.1 & 167 \\
\hline
\end{tabular}


Appendix 2.-Continued.

\begin{tabular}{|c|c|c|c|c|c|c|c|c|c|c|}
\hline \multirow[b]{2}{*}{ Samp I $\theta$} & \multicolumn{2}{|c|}{$\frac{\text { Bul|m|nel Ia }}{\text { olegant|ss Ima }}$} & \multicolumn{2}{|c|}{$\frac{\text { Caucas Ina }}{\text { sp. }}$} & \multicolumn{2}{|c|}{$\begin{array}{l}\text { Uviger Ina cf. } \\
\text { U. subperegrina }\end{array}$} & \multicolumn{2}{|c|}{$\frac{\text { Bollvina }}{\text { pl|catella }}$} & \multicolumn{2}{|c|}{$\frac{\text { Aster lger Inata }}{\text { sp. }}$} \\
\hline & $\%$ & no. & $\%$ & no. & $\%$ & no. & $\%$ & no. & $\%$ & no. \\
\hline$A-1$ & 45.6 & 290 & 0.9 & 6 & 0.0 & 0 & 0.0 & 0 & 0.3 & 2 \\
\hline$A-2$ & 36.2 & 221 & 0.6 & 4 & 0.2 & 1 & 0.6 & 2 & 0.0 & 0 \\
\hline$A-3$ & 51.9 & 684 & 0.2 & 2 & 0.3 & 4 & 0.2 & 2 & 0.0 & 0 \\
\hline$A-4$ & 42.8 & 344 & 0.0 & 0 & 0.0 & 0 & 0.7 & 6 & 0.0 & 0 \\
\hline$A-5$ & 41.4 & 412 & 0.8 & 8 & 0.0 & 0 & 0.6 & 6 & 0.0 & 0 \\
\hline B-1 & 51.8 & 568 & 0.2 & 2 & 0.2 & 2 & 0.4 & 4 & 0.4 & 4 \\
\hline$B-2$ & 45.1 & 190 & 0.5 & 2 & 0.0 & 0 & 0.2 & 1 & 0.0 & 0 \\
\hline$B-3$ & 39.0 & 123 & 0.3 & 1 & 0.0 & 0 & 0.3 & 1 & 0.3 & 1 \\
\hline$B-4$ & 33.4 & 218 & 0.0 & 0 & 0.0 & 0 & 0.3 & 2 & 0.0 & 0 \\
\hline$B-5$ & 51.2 & 388 & 0.0 & 0 & 0.0 & 0 & 0.0 & 0 & 0.0 & 0 \\
\hline$C-1$ & 47.1 & 632 & 0.4 & 6 & 0.0 & 0 & 0.4 & 6 & 0.6 & 8 \\
\hline$c-2$ & 49.7 & 548 & 0.6 & 7 & 0.0 & 0 & 0.4 & 5 & 0.2 & 2 \\
\hline$c-3$ & 43.7 & 280 & 0.6 & 4 & 0.0 & 0 & 0.6 & 4 & 0.0 & 0 \\
\hline$C-4$ & 51.3 & 432 & 0.5 & 4 & 0.0 & 0 & 0.0 & 0 & 0.0 & 0 \\
\hline$C-5$ & 43.8 & 239 & 1.3 & 7 & 0.0 & 0 & 0.2 & 1 & 0.2 & 1 \\
\hline$D-1$ & 34.1 & 47 & 0.7 & 1 & 0.0 & 0 & 0.0 & 0 & 1.4 & 2 \\
\hline$D-2$ & 33.5 & 119 & 0.3 & 1 & 0.0 & 0 & 0.3 & 1 & 0.0 & 0 \\
\hline$D-3$ & 45.7 & 159 & 0.0 & 0 & 0.3 & 1 & 0.0 & 0 & 0.3 & 1 \\
\hline$D-4$ & 39.7 & 234 & 0.7 & 4 & 0.0 & 0 & 0.0 & 0 & 0.3 & 2 \\
\hline$D-5$ & 41.6 & 352 & 1.4 & 12 & 0.0 & 0 & 0.5 & 4 & 0.2 & 2 \\
\hline$E-1$ & 37.3 & 169 & 0.0 & 0 & 0.3 & 1 & 0.9 & 4 & 0.3 & 1 \\
\hline$E-2$ & 38.5 & 183 & 0.6 & 3 & 0.0 & 0 & 0.3 & 1 & 0.0 & 0 \\
\hline$E-3$ & 42.7 & 536 & 0.0 & 0 & 0.0 & 0 & 0.6 & 8 & 0.6 & 8 \\
\hline$E-4$ & 44.3 & 416 & 0.2 & 2 & 0.0 & 0 & 0.2 & 2 & 0.2 & 2 \\
\hline$E-5$ & 42.0 & 418 & 0.2 & 2 & 0.0 & 0 & 0.0 & 0 & 0.6 & 6 \\
\hline$F-1$ & 48.8 & 752 & 0.3 & 4 & 0.0 & 0 & 0.4 & 6 & 0.1 & 2 \\
\hline$F-2$ & 43.9 & 494 & 0.4 & 4 & 0.0 & 0 & 0.7 & 8 & 0.2 & 2 \\
\hline$F-3$ & 48.5 & 452 & 1.1 & 10 & 0.2 & 2 & 0.2 & 2 & 0.2 & 2 \\
\hline$F-4$ & 41.7 & 566 & 0.3 & 4 & 0.0 & 0 & 0.1 & 2 & 0.3 & 4 \\
\hline$F-5$ & 47.6 & 308 & 0.4 & 3 & 0.2 & 1 & 0.6 & 4 & 0.2 & 1 \\
\hline G-1 & 39.7 & 239 & 0.2 & 1 & 0.2 & 1 & 0.7 & 4 & 0.0 & 0 \\
\hline G-2 & 37.7 & 120 & 0.3 & 1 & 0.0 & 0 & 0.3 & 1 & 0.0 & 0 \\
\hline G-3 & 34.2 & 81 & 1.7 & 4 & 0.0 & 0 & 0.4 & 1 & 0.0 & 0 \\
\hline G-4 & 44.2 & 364 & 0.0 & 0 & 0.0 & 0 & 0.5 & 4 & 0.5 & 4 \\
\hline$G-5$ & 46.0 & 412 & 0.9 & 8 & 0.0 & 0 & 0.4 & 4 & 0.0 & 0 \\
\hline $\mathrm{H}-1$ & 30.3 & 95 & 0.6 & 2 & 0.0 & 0 & 0.9 & 3 & 0.0 & 0 \\
\hline $\mathrm{H}-2$ & 49.6 & 660 & 0.1 & 2 & 0.0 & 0 & 0.3 & 4 & 0.1 & 2 \\
\hline $\mathrm{H}-3$ & 44.3 & 478 & 0.6 & 6 & 0.0 & 0 & 0.2 & 2 & 0.0 & 0 \\
\hline $\mathrm{H}-4$ & 46.8 & 410 & 0.2 & 2 & 0.0 & 0 & 0.2 & 2 & 0.0 & 0 \\
\hline $\mathrm{H}-5$ & 42.2 & 159 & 0.8 & 3 & 0.0 & 0 & 0.5 & 2 & 0.0 & 0 \\
\hline $\mid-1$ & 34.9 & 290 & 0.2 & 2 & 0.2 & 2 & 0.0 & 0 & 0.2 & 2 \\
\hline $1-2$ & 40.2 & 506 & 0.6 & 8 & 0.0 & 0 & 0.3 & 4 & 0.2 & 2 \\
\hline $1-3$ & 34.5 & 90 & 1.1 & 3 & 0.0 & 0 & 0.0 & 0 & 0.0 & 0 \\
\hline $1-4$ & 43.6 & 316 & 0.5 & 4 & 0.0 & 0 & 0.3 & 2 & 0.0 & 0 \\
\hline $1-5$ & 36.4 & 168 & 0.9 & 4 & 0.0 & 0 & 0.6 & 3 & 0.0 & 0 \\
\hline
\end{tabular}


Appendix 2.-Continued.

Splroplectammina Florllus? Anomalinoldes Nonlon cf. Bullminella cf. sp. sp. $? \mathrm{sp}$. N.cassldulinoldes B. brevlor

\begin{tabular}{|c|c|c|c|c|c|c|c|c|c|c|}
\hline Samp le & $\%$ & no. & $\%$ & no. & $\%$ & no. & $\%$ & no. & $\%$ & no. \\
\hline$A-1$ & 0.0 & 0 & 0.3 & 2 & 0.0 & 0 & 0.0 & 0 & 0.0 & 0 \\
\hline$A-2$ & 0.0 & 0 & 0.0 & 0 & 0.2 & 1 & 0.2 & 1 & 0.2 & 1 \\
\hline$A-3$ & 0.0 & 0 & 0.0 & 0 & 0.0 & 0 & 0.0 & 0 & 0.0 & 0 \\
\hline$A-4$ & 0.0 & 0 & 0.0 & 0 & 0.0 & 0 & 0.0 & 0 & 0.2 & 2 \\
\hline$A-5$ & 0.0 & 0 & 0.0 & 0 & 0.0 & 0 & 0.0 & 0 & 0.0 & 0 \\
\hline$B-1$ & 0.0 & 0 & 0.0 & 0 & 0.0 & 0 & 0.0 & 0 & 0.0 & 0 \\
\hline$B-2$ & 0.5 & 2 & 0.0 & 0 & 0.0 & 0 & 0.0 & 0 & 0.0 & 0 \\
\hline$B-3$ & 0.0 & 0 & 0.0 & 0 & 0.0 & 0 & 0.0 & 0 & 0.0 & 0 \\
\hline$B-4$ & 0.0 & 0 & 0.3 & 2 & 0.0 & 0 & 0.0 & 0 & 0.0 & 0 \\
\hline$B-5$ & 0.0 & 0 & 0.3 & 2 & 0.0 & 0 & 0.0 & 0 & 0.0 & 0 \\
\hline$C-1$ & 0.0 & 0 & 0.3 & 4 & 0.0 & 0 & 0.0 & 0 & 0.0 & 0 \\
\hline$c-2$ & 0.2 & 2 & 0.2 & 2 & 0.0 & 0 & 0.0 & 0 & 0.1 & 1 \\
\hline$c-3$ & 0.0 & 0 & 0.0 & 0 & 0.0 & 0 & 0.3 & 2 & 0.0 & 0 \\
\hline$C-4$ & 0.5 & 4 & 0.0 & 0 & 0.0 & 0 & 0.0 & 0 & 0.0 & 0 \\
\hline$C-5$ & 0.0 & 0 & 0.0 & 0 & 0.0 & 0 & 0.0 & 0 & 0.0 & 0 \\
\hline$D-1$ & 1.4 & 2 & 0.7 & 1 & 0.0 & 0 & 0.0 & 0 & 0.0 & 0 \\
\hline$D-2$ & 0.0 & 0 & 0.6 & 2 & 0.0 & 0 & 0.0 & 0 & 0.0 & 0 \\
\hline$D-3$ & 0.0 & 0 & 0.0 & 0 & 0.0 & 0 & 0.0 & 0 & 0.0 & 0 \\
\hline$D-4$ & 0.0 & 0 & 0.0 & 0 & 0.0 & 0 & 0.0 & 0 & 0.0 & 0 \\
\hline$D-5$ & 0.0 & 0 & 0.0 & 0 & 0.0 & 0 & 0.0 & 0 & 0.0 & 0 \\
\hline$E-1$ & 0.0 & 0 & 0.0 & 0 & 0.0 & 0 & 0.0 & 0 & 0.0 & 0 \\
\hline$E-2$ & 0.0 & 0 & 0.0 & 0 & 0.0 & 0 & 0.0 & 0 & 0.0 & 0 \\
\hline$E-3$ & 0.2 & 2 & 0.0 & 0 & 0.0 & 0 & 0.0 & 0 & 0.0 & 0 \\
\hline$E-4$ & 0.0 & 0 & 0.0 & 0 & 0.0 & 0 & 0.0 & 0 & 0.0 & 0 \\
\hline$E-5$ & 0.0 & 0 & 0.0 & 0 & 0.0 & 0 & 0.0 & 0 & 0.0 & 0 \\
\hline$F-1$ & 0.0 & 0 & 0.0 & 0 & 0.0 & 0 & 0.1 & 2 & 0.0 & 0 \\
\hline$F-2$ & 0.0 & 0 & 0.0 & 0 & 0.0 & 0 & 0.0 & 0 & 0.0 & 0 \\
\hline$F-3$ & 0.0 & 0 & 0.0 & 0 & 0.0 & 0 & 0.0 & 0 & 0.0 & 0 \\
\hline$F-4$ & 0.0 & 0 & 0.0 & 0 & 0.0 & 0 & 0.0 & 0 & 0.0 & 0 \\
\hline$F-5$ & 0.0 & 0 & 0.2 & 1 & 0.0 & 0 & 0.0 & 0 & 0.0 & 0 \\
\hline$G-1$ & 0.0 & 0 & 0.0 & 0 & 0.0 & 0 & 0.0 & 0 & 0.0 & 0 \\
\hline$G-2$ & 0.0 & 0 & 0.3 & 1 & 0.0 & 0 & 0.0 & 0 & 0.0 & 0 \\
\hline$G-3$ & 0.0 & 0 & 0.0 & 0 & 0.0 & 0 & 0.0 & 0 & 0.0 & 0 \\
\hline G-4 & 0.0 & 0 & 0.0 & 0 & 0.0 & 0 & 0.0 & 0 & 0.0 & 0 \\
\hline G-5 & 0.0 & 0 & 0.0 & 0 & 0.0 & 0 & 0.0 & 0 & 0.0 & 0 \\
\hline $\mathrm{H}-1$ & 0.0 & 0 & 0.0 & 0 & 0.0 & 0 & 0.0 & 0 & 0.0 & 0 \\
\hline $\mathrm{H}-2$ & 0.0 & 0 & 0.0 & 0 & 0.0 & 0 & 0.0 & 0 & 0.0 & 0 \\
\hline $\mathrm{H}-3$ & 0.0 & 0 & 0.0 & 0 & 0.0 & 0 & 0.0 & 0 & 0.0 & 0 \\
\hline $\mathrm{H}-4$ & 0.0 & 0 & 0.0 & 0 & 0.0 & 0 & 0.0 & 0 & 0.0 & 0 \\
\hline $\mathrm{H}-5$ & 0.0 & 0 & 0.0 & 0 & 0.0 & 0 & 0.0 & 0 & 0.0 & 0 \\
\hline $1-1$ & 0.2 & 2 & 0.0 & 0 & 0.0 & 0 & 0.0 & 0 & 0.0 & 0 \\
\hline $1-2$ & 0.2 & 2 & 0.2 & 2 & 0.0 & 0 & 0.0 & 0 & 0.0 & 0 \\
\hline $1-3$ & 0.0 & 0 & 0.0 & 0 & 0.0 & 0 & 0.0 & 0 & 0.0 & 0 \\
\hline $1-4$ & 0.0 & 0 & 0.0 & 0 & 0.0 & 0 & 0.0 & 0 & 0.0 & 0 \\
\hline $1-5$ & 0.0 & 0 & 0.0 & 0 & 0.0 & 0 & 0.0 & 0 & 0.0 & 0 \\
\hline
\end{tabular}


Appendix 2.-Continued.

\begin{tabular}{|c|c|c|c|c|c|c|c|c|c|c|}
\hline \multirow[b]{2}{*}{ Samp le } & \multicolumn{2}{|c|}{$\begin{array}{l}\text { BulImInella cf. } \\
\text { B.subfuslform Is }\end{array}$} & \multicolumn{2}{|c|}{$\begin{array}{l}\text { Bol IvIna cf. } \\
\text { B. IImbata }\end{array}$} & \multicolumn{2}{|c|}{$\frac{\text { Elph|d|um }}{\text { sp. }}$} & \multicolumn{2}{|c|}{$\frac{\text { Tr Ifar Ina }}{\text { sp. }}$} & \multicolumn{2}{|c|}{$\frac{\text { Cass IduIIna }}{\text { sp. }}$} \\
\hline & $\%$ & no. & $\mathscr{x}$ & no. & $\%$ & no. & $\%$ & no. & $\%$ & no. \\
\hline$A-1$ & 0.0 & 0 & 0.0 & 0 & 0.0 & 0 & 0.0 & 0 & 0.0 & 0 \\
\hline$A-2$ & 0.0 & 0 & 0.2 & 1 & 0.0 & 0 & 0.0 & 0 & 0.0 & 0 \\
\hline$A-3$ & 0.0 & 0 & 0.0 & 0 & 0.2 & 2 & 0.2 & 2 & 0.0 & 0 \\
\hline$A-4$ & 0.0 & 0 & 0.0 & 0 & 0.0 & 0 & 0.0 & 0 & 0.2 & 2 \\
\hline$A-5$ & 0.2 & 2 & 0.0 & 0 & 0.0 & 0 & 0.2 & 2 & 0.4 & 4 \\
\hline B-1 & 0.0 & 0 & 0.0 & 0 & 0.0 & 0 & 0.0 & 0 & 0.0 & 0 \\
\hline$B-2$ & 0.0 & 0 & 0.0 & 0 & 0.0 & 0 & 0.2 & 1 & 0.2 & 1 \\
\hline$B-3$ & 0.0 & 0 & 0.0 & 0 & 0.0 & 0 & 0.0 & 0 & 0.3 & 1 \\
\hline$B-4$ & 0.0 & 0 & 0.0 & 0 & 0.0 & 0 & 0.0 & 0 & 0.0 & 0 \\
\hline$B-5$ & 0.0 & 0 & 0.0 & 0 & 0.0 & 0 & 0.0 & 0 & 0.0 & 0 \\
\hline$C-1$ & 0.0 & 0 & 0.0 & 0 & 0.0 & 0 & 0.0 & 0 & 0.0 & 0 \\
\hline$C-2$ & 0.0 & 0 & 0.0 & 0 & 0.0 & 0 & 0.1 & 1 & 0.1 & 1 \\
\hline$C-3$ & 0.0 & 0 & 0.0 & 0 & 0.0 & 0 & 0.3 & 2 & 0.0 & 0 \\
\hline$C-4$ & 0.0 & 0 & 0.0 & 0 & 0.2 & 2 & 0.0 & 0 & 0.0 & 0 \\
\hline$C-5$ & 0.2 & 1 & 0.0 & 0 & 0.0 & 0 & 0.0 & 0 & 0.0 & 0 \\
\hline$D-1$ & 0.0 & 0 & 0.0 & 0 & 0.0 & 0 & 0.0 & 0 & 0.0 & 0 \\
\hline$D-2$ & 0.3 & 1 & 0.0 & 0 & 0.0 & 0 & 0.0 & 0 & 0.0 & 0 \\
\hline$D-3$ & 0.3 & 1 & 0.0 & 0 & 0.0 & 0 & 0.0 & 0 & 0.0 & 0 \\
\hline$D-4$ & 0.0 & 0 & 0.0 & 0 & 0.0 & 0 & 0.3 & 2 & 0.7 & 4 \\
\hline$D-5$ & 0.5 & 4 & 0.0 & 0 & 0.0 & 0 & 0.5 & 4 & 0.2 & 2 \\
\hline$E-1$ & 0.0 & 0 & 0.0 & 0 & 0.0 & 0 & 0.0 & 0 & 0.9 & 4 \\
\hline$E-2$ & 0.0 & 0 & 0.0 & 0 & 0.0 & 0 & 0.0 & 0 & 0.3 & 1 \\
\hline$E-3$ & 0.0 & 0 & 0.0 & 0 & 0.0 & 0 & 0.0 & 0 & 0.2 & 2 \\
\hline$E-4$ & 0.0 & 0 & 0.0 & 0 & 0.0 & 0 & 0.0 & 0 & 0.2 & 2 \\
\hline$E-5$ & 0.2 & 2 & 0.0 & 0 & 0.0 & 0 & 0.0 & 0 & 0.2 & 2 \\
\hline$F-1$ & 0.1 & 2 & 0.0 & 0 & 0.0 & 0 & 0.0 & 0 & 0.0 & 0 \\
\hline$F-2$ & 0.4 & 4 & 0.0 & 0 & 0.0 & 0 & 0.0 & 0 & 0.0 & 0 \\
\hline$F-3$ & 0.2 & 2 & 0.0 & 0 & 0.0 & 0 & 0.0 & 0 & 0.0 & 0 \\
\hline$F-4$ & 0.0 & 0 & 0.0 & 0 & 0.0 & 0 & 0.0 & 0 & 0.3 & 4 \\
\hline$F-5$ & 0.0 & 0 & 0.0 & 0 & 0.0 & 0 & 0.0 & 0 & 0.0 & 0 \\
\hline G-1 & 0.2 & 1 & 0.0 & 0 & 0.0 & 0 & 0.0 & 0 & 0.0 & 0 \\
\hline G-2 & 0.0 & 0 & 0.0 & 0 & 0.0 & 0 & 0.0 & 0 & 0.3 & 1 \\
\hline G-3 & 0.0 & 0 & 0.0 & 0 & 0.0 & 0 & 0.0 & 0 & 0.0 & 0 \\
\hline G-4 & 0.0 & 0 & 0.0 & 0 & 0.2 & 2 & 0.0 & 0 & 0.5 & 4 \\
\hline G-5 & 0.0 & 0 & 0.0 & 0 & 0.0 & 0 & 0.0 & 0 & 0.2 & 2 \\
\hline $\mathrm{H}-1$ & 0.0 & 0 & 0.0 & 0 & 0.0 & 0 & 0.0 & 0 & 0.3 & 1 \\
\hline $\mathrm{H}-2$ & 0.0 & 0 & 0.0 & 0 & 0.0 & 0 & 0.0 & 0 & 0.1 & 2 \\
\hline $\mathrm{H}-3$ & 0.2 & 2 & 0.0 & 0 & 0.0 & 0 & 0.0 & 0 & 0.0 & 0 \\
\hline $\mathrm{H}-4$ & 0.2 & 2 & 0.0 & 0 & 0.0 & 0 & 0.0 & 0 & 0.5 & 4 \\
\hline $\mathrm{H}-5$ & 0.0 & 0 & 0.0 & 0 & 0.0 & 0 & 0.0 & 0 & 0.0 & 0 \\
\hline I-1 & 0.0 & 0 & 0.0 & 0 & 0.0 & 0 & 0.0 & 0 & 0.2 & 2 \\
\hline $1-2$ & 0.2 & 2 & 0.0 & 0 & 0.0 & 0 & 0.0 & 0 & 0.0 & 0 \\
\hline $1-3$ & 0.0 & 0 & 0.0 & 0 & 0.0 & 0 & 0.0 & 0 & 0.0 & 0 \\
\hline $1-4$ & 0.0 & 0 & 0.0 & 0 & 0.0 & 0 & 0.0 & 0 & 0.0 & 0 \\
\hline $1-5$ & 0.0 & 0 & 0.0 & 0 & 0.0 & 0 & 0.0 & 0 & 0.0 & 0 \\
\hline
\end{tabular}


Appendix 2.-Continued.

\begin{tabular}{|c|c|c|c|c|c|c|c|c|c|c|}
\hline \multirow[b]{2}{*}{ Sample } & \multicolumn{2}{|c|}{ Bollvina cf. } & \multicolumn{2}{|c|}{$\frac{\text { FIssur Ina }}{\text { sp. }}$} & \multicolumn{2}{|c|}{$\frac{\text { Flssur Ina }}{\text { Iuclda }}$} & \multicolumn{2}{|c|}{$\frac{\text { Globocass Idul Ina }}{\text { sp. }}$} & \multicolumn{2}{|c|}{$\frac{\text { Fursenkolna }}{\text { fus IformIs }}$} \\
\hline & $\%$ & no. & $\%$ & no. & $\%$ & no. & $\%$ & no. & $\%$ & no. \\
\hline$A-1$ & 0.0 & 0 & 0.0 & 0 & 0.0 & 0 & 0.0 & 0 & 0.0 & 0 \\
\hline$A-2$ & 0.0 & 0 & 0.0 & 0 & 0.0 & 0 & 0.0 & 0 & 0.0 & 0 \\
\hline$A-3$ & 0.0 & 0 & 0.0 & 0 & 0.0 & 0 & 0.0 & 0 & 0.0 & 0 \\
\hline A-4 & 0.0 & 0 & 0.0 & 0 & 0.0 & 0 & 0.0 & 0 & 0.0 & 0 \\
\hline$A-5$ & 0.0 & 0 & 0.0 & 0 & 0.0 & 0 & 0.0 & 0 & 0.0 & 0 \\
\hline B-1 & 0.2 & 2 & 0.0 & 0 & 0.0 & 0 & 0.0 & 0 & 0.0 & 0 \\
\hline$B-2$ & 0.0 & 0 & 0.2 & 1 & 0.0 & 0 & 0.0 & 0 & 0.0 & 0 \\
\hline$B-3$ & 0.0 & 0 & 0.0 & 0 & 0.6 & 2 & 0.0 & 0 & 0.0 & 0 \\
\hline$B-4$ & 0.0 & 0 & 0.0 & 0 & 0.0 & 0 & 0.0 & 0 & 0.0 & 0 \\
\hline B-5 & 0.0 & 0 & 0.0 & 0 & 0.0 & 0 & 0.3 & 2 & 0.0 & 0 \\
\hline$C-1$ & 0.0 & 0 & 0.0 & 0 & 0.0 & 0 & 0.2 & 2 & 0.0 & 0 \\
\hline$C-2$ & 0.0 & 0 & 0.0 & 0 & 0.1 & 1 & 0.0 & 0 & 0.0 & 0 \\
\hline$c-3$ & 0.0 & 0 & 0.0 & 0 & 0.0 & 0 & 0.0 & 0 & 0.0 & 0 \\
\hline$C-4$ & 0.0 & 0 & 0.0 & 0 & 0.0 & 0 & 0.0 & 0 & 0.0 & 0 \\
\hline$C-5$ & 0.0 & 0 & 0.0 & 0 & 0.0 & 0 & 0.0 & 0 & 0.0 & 0 \\
\hline$D-1$ & 0.0 & 0 & 0.0 & 0 & 0.0 & 0 & 0.0 & 0 & 0.0 & 0 \\
\hline$D-2$ & 0.0 & 0 & 0.0 & 0 & 0.0 & 0 & 0.0 & 0 & 0.0 & 0 \\
\hline$D-3$ & 0.0 & 0 & 0.0 & 0 & 0.0 & 0 & 0.0 & 0 & 0.0 & 0 \\
\hline$D-4$ & 0.0 & 0 & 0.0 & 0 & 0.0 & 0 & 0.0 & 0 & 0.0 & 0 \\
\hline D-5 & 0.0 & 0 & 0.0 & 0 & 0.0 & 0 & 0.0 & 0 & 0.0 & 0 \\
\hline$E-1$ & 0.0 & 0 & 0.0 & 0 & 0.3 & 1 & 0.0 & 0 & 0.0 & 0 \\
\hline$E-2$ & 0.0 & 0 & 0.0 & 0 & 0.0 & 0 & 0.0 & 0 & 0.0 & 0 \\
\hline$E-3$ & 0.0 & 0 & 0.0 & 0 & 0.0 & 0 & 0.0 & 0 & 0.0 & 0 \\
\hline$E-4$ & 0.0 & 0 & 0.0 & 0 & 0.0 & 0 & 0.0 & 0 & 0.0 & 0 \\
\hline E-5 & 0.0 & 0 & 0.0 & 0 & 0.0 & 0 & 0.0 & 0 & 0.2 & 2 \\
\hline$F-1$ & 0.0 & 0 & 0.0 & 0 & 0.0 & 0 & 0.3 & 4 & 0.0 & 0 \\
\hline$F-2$ & 0.0 & 0 & 0.0 & 0 & 0.0 & 0 & 0.0 & 0 & 0.0 & 0 \\
\hline$F-3$ & 0.0 & 0 & 0.0 & 0 & 0.0 & 0 & 0.0 & 0 & 0.2 & 2 \\
\hline$F-4$ & 0.0 & 0 & 0.0 & 0 & 0.3 & 4 & 0.0 & 0 & 0.0 & 0 \\
\hline$F-5$ & 0.0 & 0 & 0.0 & 0 & 0.0 & 0 & 0.0 & 0 & 0.0 & 0 \\
\hline G-1 & 0.2 & 1 & 0.0 & 0 & 0.0 & 0 & 0.0 & 0 & 0.0 & 0 \\
\hline G-2 & 0.0 & 0 & 0.0 & 0 & 0.3 & 1 & 0.0 & 0 & 0.0 & 0 \\
\hline G-3 & 0.0 & 0 & 0.0 & 0 & 0.0 & 0 & 0.0 & 0 & 0.0 & 0 \\
\hline$G-4$ & 0.0 & 0 & 0.0 & 0 & 0.2 & 2 & 0.0 & 0 & 0.0 & 0 \\
\hline G-5 & 0.0 & 0 & 0.0 & 0 & 0.0 & 0 & 0.0 & 0 & 0.0 & 0 \\
\hline $\mathrm{H}-1$ & 0.0 & 0 & 0.0 & 0 & 0.0 & 0 & 0.0 & 0 & 0.0 & 0 \\
\hline $\mathrm{H}-2$ & 0.0 & 0 & 0.0 & 0 & 0.0 & 0 & 0.0 & 0 & 0.0 & 0 \\
\hline $\mathrm{H}-3$ & 0.0 & 0 & 0.0 & 0 & 0.0 & 0 & 0.0 & 0 & 0.0 & 0 \\
\hline $\mathrm{H}-4$ & 0.0 & 0 & 0.0 & 0 & 0.5 & 4 & 0.0 & 0 & 0.0 & 0 \\
\hline $\mathrm{H}-5$ & 0.0 & 0 & 0.0 & 0 & 0.0 & 0 & 0.0 & 0 & 0.0 & 0 \\
\hline $\mid-1$ & 0.0 & 0 & 0.0 & 0 & 0.0 & 0 & 0.0 & 0 & 0.2 & 2 \\
\hline $1-2$ & 0.0 & 0 & 0.0 & 0 & 0.0 & 0 & 0.0 & 0 & 0.0 & 0 \\
\hline $1-3$ & 0.0 & 0 & 0.0 & 0 & 0.4 & 1 & 0.0 & 0 & 0.0 & 0 \\
\hline $1-4$ & 0.0 & 0 & 0.0 & 0 & 0.0 & 0 & 0.0 & 0 & 0.0 & 0 \\
\hline $1-5$ & 0.0 & 0 & 0.0 & 0 & 0.0 & 0 & 0.0 & 0 & 0.0 & 0 \\
\hline
\end{tabular}


Appendix 2.-Continued.

\begin{tabular}{|c|c|c|c|c|c|c|c|c|c|c|}
\hline \multirow[b]{2}{*}{ Samp le } & \multicolumn{2}{|c|}{$\frac{\text { Non lonella }}{\text { sp. }}$} & \multicolumn{2}{|c|}{$\frac{001 \text { Ina }}{s p .}$} & \multicolumn{2}{|c|}{$\frac{\text { Neoconorb Ina }}{\text { terguem I }}$} & \multicolumn{2}{|c|}{$\begin{array}{l}\text { Bollvina aff. } \\
\text { B.paclfica }\end{array}$} & \multicolumn{2}{|c|}{$\begin{array}{l}\text { Globocass Idul Ina } \\
\text { cf. G.subglobosa }\end{array}$} \\
\hline & $\%$ & no. & $\%$ & no. & $\%$ & no. & $\%$ & no. & $\%$ & no. \\
\hline$A-1$ & 0.0 & 0 & 0.0 & 0 & 0.0 & 0 & 0.0 & 0 & 0.0 & 0 \\
\hline$A-2$ & 0.0 & 0 & 0.0 & 0 & 0.0 & 0 & 0.0 & 0 & 0.0 & 0 \\
\hline$A-3$ & 0.0 & 0 & 0.0 & 0 & 0.0 & 0 & 0.0 & 0 & 0.0 & 0 \\
\hline$A-4$ & 0.0 & 0 & 0.0 & 0 & 0.0 & 0 & 0.0 & 0 & 0.0 & 0 \\
\hline$A-5$ & 0.0 & 0 & 0.0 & 0 & 0.0 & 0 & 0.0 & 0 & 0.0 & 0 \\
\hline$B-1$ & 0.0 & 0 & 0.0 & 0 & 0.0 & 0 & 0.0 & 0 & 0.0 & 0 \\
\hline$B-2$ & 0.0 & 0 & 0.0 & 0 & 0.0 & 0 & 0.0 & 0 & 0.0 & 0 \\
\hline$B-3$ & 0.0 & 0 & 0.0 & 0 & 0.0 & 0 & 0.0 & 0 & 0.0 & 0 \\
\hline B-4 & 0.0 & 0 & 0.0 & 0 & 0.0 & 0 & 0.0 & 0 & 0.0 & 0 \\
\hline B-5 & 0.0 & 0 & 0.0 & 0 & 0.0 & 0 & 0.0 & 0 & 0.0 & 0 \\
\hline$c-1$ & 0.2 & 2 & 0.0 & 0 & 0.3 & 4 & 0.4 & 6 & 0.0 & 0 \\
\hline$C-2$ & 0.0 & 0 & 0.0 & 0 & 0.0 & 0 & 0.0 & 0 & 0.0 & 0 \\
\hline$C-3$ & 0.0 & 0 & 0.0 & 0 & 0.0 & 0 & 0.0 & 0 & 0.0 & 0 \\
\hline$C-4$ & 0.0 & 0 & 0.0 & 0 & 0.0 & 0 & 0.0 & 0 & 0.0 & 0 \\
\hline$C-5$ & 0.0 & 0 & 0.0 & 0 & 0.0 & 0 & 0.0 & 0 & 0.0 & 0 \\
\hline$D-1$ & 0.0 & 0 & 0.0 & 0 & 0.0 & 0 & 0.0 & 0 & 0.0 & 0 \\
\hline$D-2$ & 0.0 & 0 & 0.0 & 0 & 0.0 & 0 & 0.0 & 0 & 0.0 & 0 \\
\hline$D-3$ & 0.0 & 0 & 0.0 & 0 & 0.0 & 0 & 0.0 & 0 & 0.0 & 0 \\
\hline$D-4$ & 0.0 & 0 & 0.0 & 0 & 0.0 & 0 & 0.0 & 0 & 0.0 & 0 \\
\hline$D-5$ & 0.0 & 0 & 0.0 & 0 & 0.0 & 0 & 0.0 & 0 & 0.0 & 0 \\
\hline$E-1$ & 0.0 & 0 & 0.0 & 0 & 0.0 & 0 & 0.0 & 0 & 0.0 & 0 \\
\hline$E-2$ & 0.0 & 0 & 0.0 & 0 & 0.0 & 0 & 0.0 & 0 & 0.0 & 0 \\
\hline$E-3$ & 0.0 & 0 & 0.0 & 0 & 0.0 & 0 & 0.0 & 0 & 0.0 & 0 \\
\hline$E-4$ & 0.0 & 0 & 0.0 & 0 & 0.0 & 0 & 0.0 & 0 & 0.0 & 0 \\
\hline$E-5$ & 0.0 & 0 & 0.0 & 0 & 0.0 & 0 & 0.0 & 0 & 0.0 & 0 \\
\hline$F-1$ & 0.0 & 0 & 0.0 & 0 & 0.0 & 0 & 0.0 & 0 & 0.1 & 2 \\
\hline$F-2$ & 0.0 & 0 & 0.0 & 0 & 0.0 & 0 & 0.0 & 0 & 0.0 & 0 \\
\hline$F-3$ & 0.0 & 0 & 0.0 & 0 & 0.0 & 0 & 0.0 & 0 & 0.0 & 0 \\
\hline$F-4$ & 0.0 & 0 & 0.0 & 0 & 0.0 & 0 & 0.0 & 0 & 0.0 & 0 \\
\hline$F-5$ & 0.0 & 0 & 0.0 & 0 & 0.0 & 0 & 0.0 & 0 & 0.0 & 0 \\
\hline G-1 & 0.0 & 0 & 0.0 & 0 & 0.0 & 0 & 0.0 & 0 & 0.0 & 0 \\
\hline$G-2$ & 0.0 & 0 & 0.0 & 0 & 0.0 & 0 & 0.0 & 0 & 0.0 & 0 \\
\hline G-3 & 0.0 & 0 & 0.0 & 0 & 0.0 & 0 & 0.0 & 0 & 0.0 & 0 \\
\hline G-4 & 0.0 & 0 & 0.0 & 0 & 0.0 & 0 & 0.0 & 0 & 0.0 & 0 \\
\hline G-5 & 0.0 & 0 & 0.0 & 0 & 0.0 & 0 & 0.0 & 0 & 0.0 & 0 \\
\hline $\mathrm{H}-1$ & 0.0 & 0 & 0.0 & 0 & 0.0 & 0 & 0.0 & 0 & 0.0 & 0 \\
\hline $\mathrm{H}-2$ & 0.0 & 0 & 0.0 & 0 & 0.0 & 0 & 0.0 & 0 & 0.0 & 0 \\
\hline $\mathrm{H}-3$ & 0.0 & 0 & 0.0 & 0 & 0.0 & 0 & 0.0 & 0 & 0.0 & 0 \\
\hline $\mathrm{H}-4$ & 0.0 & 0 & 0.0 & 0 & 0.0 & 0 & 0.0 & 0 & 0.0 & 0 \\
\hline$H-5$ & 0.0 & 0 & 0.0 & 0 & 0.0 & 0 & 0.0 & 0 & 0.0 & 0 \\
\hline $1-1$ & 0.0 & 0 & 0.2 & 2 & 0.0 & 0 & 0.0 & 0 & 0.0 & 0 \\
\hline $1-2$ & 0.0 & 0 & 0.0 & 0 & 0.0 & 0 & 0.0 & 0 & 0.0 & 0 \\
\hline $1-3$ & 0.0 & 0 & 0.0 & 0 & 0.0 & 0 & 0.0 & 0 & 0.0 & 0 \\
\hline $1-4$ & 0.0 & 0 & 0.0 & 0 & 0.0 & 0 & 0.0 & 0 & 0.0 & 0 \\
\hline $1-5$ & 0.0 & 0 & 0.0 & 0 & 0.0 & 0 & 0.0 & 0 & 0.0 & 0 \\
\hline
\end{tabular}


Appendix 2.-Continued.

\begin{tabular}{|c|c|c|c|c|c|c|c|c|c|c|}
\hline \multirow[b]{2}{*}{ Samp le } & \multicolumn{2}{|c|}{$\frac{\text { Lagena }}{\mid \text { aevis }}$} & \multicolumn{2}{|c|}{$\frac{\text { Astrononlon }}{\text { sp. }}$} & \multicolumn{2}{|c|}{$\frac{\text { Spl rop lectammina }}{\text { sp. } 2}$} & \multicolumn{2}{|c|}{$\frac{\text { Pseudopoly- }}{\text { morph Ina? sp }}$} & \multicolumn{2}{|c|}{$\frac{\text { Flor Ilus }}{\text { chesapeakensis }}$} \\
\hline & $\%$ & no. & $\%$ & no. & $\%$ & no. & $\%$ & no. & $\%$ & no. \\
\hline$A-1$ & 0.0 & 0 & 0.0 & 0 & 0.0 & 0 & 0.0 & 0 & 0.0 & 0 \\
\hline$A-2$ & 0.0 & 0 & 0.0 & 0 & 0.0 & 0 & 0.0 & 0 & 0.0 & 0 \\
\hline$A-3$ & 0.0 & 0 & 0.0 & 0 & 0.0 & 0 & 0.0 & 0 & 0.0 & 0 \\
\hline$A-4$ & 0.0 & 0 & 0.0 & 0 & 0.0 & 0 & 0.0 & 0 & 0.0 & 0 \\
\hline$A-5$ & 0.0 & 0 & 0.0 & 0 & 0.0 & 0 & 0.0 & 0 & 0.0 & 0 \\
\hline$B-1$ & 0.0 & 0 & 0.0 & 0 & 0.0 & 0 & 0.0 & 0 & 0.0 & 0 \\
\hline$B-2$ & 0.0 & 0 & 0.0 & 0 & 0.0 & 0 & 0.0 & 0 & 0.0 & 0 \\
\hline$B-3$ & 0.0 & 0 & 0.0 & 0 & 0.0 & 0 & 0.0 & 0 & 0.0 & 0 \\
\hline$B-4$ & 0.0 & 0 & 0.0 & 0 & 0.0 & 0 & 0.0 & 0 & 0.0 & 0 \\
\hline$B-5$ & 0.0 & 0 & 0.0 & 0 & 0.0 & 0 & 0.0 & 0 & 0.0 & 0 \\
\hline$C-1$ & 0.0 & 0 & 0.0 & 0 & 0.0 & 0 & 0.0 & 0 & 0.0 & 0 \\
\hline$C-2$ & 0.1 & 1 & 0.0 & 0 & 0.0 & 0 & 0.0 & 0 & 0.0 & 0 \\
\hline$c-3$ & 0.3 & 2 & 0.3 & 2 & 0.0 & 0 & 0.0 & 0 & 0.0 & 0 \\
\hline$C-4$ & 0.0 & 0 & 0.0 & 0 & 0.2 & 2 & 0.2 & 2 & 0.0 & 0 \\
\hline$C-5$ & 0.0 & 0 & 0.0 & 0 & 0.0 & 0 & 0.0 & 0 & 0.0 & 0 \\
\hline$D-1$ & 0.0 & 0 & 0.0 & 0 & 0.0 & 0 & 0.0 & 0 & 0.7 & 1 \\
\hline$D-2$ & 0.0 & 0 & 0.0 & 0 & 0.0 & 0 & 0.0 & 0 & 0.0 & 0 \\
\hline$D-3$ & 0.0 & 0 & 0.0 & 0 & 0.0 & 0 & 0.0 & 0 & 0.0 & 0 \\
\hline$D-4$ & 0.0 & 0 & 0.0 & 0 & 0.0 & 0 & 0.0 & 0 & 0.0 & 0 \\
\hline$D-5$ & 0.0 & 0 & 0.0 & 0 & 0.0 & 0 & 0.0 & 0 & 0.0 & 0 \\
\hline$E-1$ & 0.6 & 3 & 0.0 & 0 & 0.0 & 0 & 0.0 & 0 & 0.0 & 0 \\
\hline$E-2$ & 0.0 & 0 & 0.0 & 0 & 0.0 & 0 & 0.0 & 0 & 0.0 & 0 \\
\hline$E-3$ & 0.0 & 0 & 0.0 & 0 & 0.0 & 0 & 0.0 & 0 & 0.0 & 0 \\
\hline$E-4$ & 0.0 & 0 & 0.0 & 0 & 0.0 & 0 & 0.0 & 0 & 0.0 & 0 \\
\hline$E-5$ & 0.0 & 0 & 0.0 & 0 & 0.0 & 0 & 0.0 & 0 & 0.0 & 0 \\
\hline$F-1$ & 0.0 & 0 & 0.0 & 0 & 0.0 & 0 & 0.0 & 0 & 0.0 & 0 \\
\hline$F-2$ & 0.0 & 0 & 0.0 & 0 & 0.0 & 0 & 0.0 & 0 & 0.0 & 0 \\
\hline$F-3$ & 0.0 & 0 & 0.0 & 0 & 0.0 & 0 & 0.0 & 0 & 0.0 & 0 \\
\hline$F-4$ & 0.0 & 0 & 0.0 & 0 & 0.0 & 0 & 0.0 & 0 & 0.0 & 0 \\
\hline$F-5$ & 0.0 & 0 & 0.0 & 0 & 0.0 & 0 & 0.0 & 0 & 0.0 & 0 \\
\hline G-1 & 0.2 & 1 & 0.0 & 0 & 0.0 & 0 & 0.0 & 0 & 0.0 & 0 \\
\hline$G-2$ & 0.0 & 0 & 0.0 & 0 & 0.0 & 0 & 0.0 & 0 & 0.0 & 0 \\
\hline G-3 & 0.0 & 0 & 0.0 & 0 & 0.0 & 0 & 0.0 & 0 & 0.0 & 0 \\
\hline G-4 & 0.0 & 0 & 0.0 & 0 & 0.0 & 0 & 0.0 & 0 & 0.0 & 0 \\
\hline G-5 & 0.0 & 0 & 0.0 & 0 & 0.0 & 0 & 0.0 & 0 & 0.0 & 0 \\
\hline $\mathrm{H}-1$ & 0.0 & 0 & 0.0 & 0 & 0.0 & 0 & 0.0 & 0 & 0.0 & 0 \\
\hline $\mathrm{H}-2$ & 0.1 & 2 & 0.0 & 0 & 0.0 & 0 & 0.0 & 0 & 0.0 & 0 \\
\hline $\mathrm{H}-3$ & 0.2 & 2 & 0.0 & 0 & 0.0 & 0 & 0.0 & 0 & 0.2 & 2 \\
\hline $\mathrm{H}-4$ & 0.0 & 0 & 0.2 & 2 & 0.0 & 0 & 0.0 & 0 & 0.0 & 0 \\
\hline $\mathrm{H}-5$ & 0.0 & 0 & 0.0 & 0 & 0.0 & 0 & 0.0 & 0 & 0.3 & 1 \\
\hline $1-1$ & 0.0 & 0 & 0.0 & 0 & 0.0 & 0 & 0.0 & 0 & 0.5 & 4 \\
\hline $1-2$ & 0.0 & 0 & 0.0 & 0 & 0.0 & 0 & 0.0 & 0 & 0.0 & 0 \\
\hline $1-3$ & 0.4 & 1 & 0.0 & 0 & 0.0 & 0 & 0.0 & 0 & 0.4 & 1 \\
\hline $1-4$ & 0.0 & 0 & 0.0 & 0 & 0.0 & 0 & 0.0 & 0 & 0.0 & 0 \\
\hline $1-5$ & 0.0 & 0 & 0.0 & 0 & 0.0 & 0 & 0.0 & 0 & 0.3 & 1 \\
\hline
\end{tabular}


Appendix 2.-Continued.

\begin{tabular}{|c|c|c|c|c|c|c|c|c|c|c|}
\hline \multirow[b]{2}{*}{ Samp I $\theta$} & \multicolumn{2}{|c|}{$\frac{\text { Dental Ina ? }}{\text { sp. }}$} & \multicolumn{2}{|c|}{$\frac{\text { Lagena }}{\mathrm{sp}}$} & \multicolumn{2}{|c|}{$\begin{array}{l}\text { Florllus cf. } \\
\text { F.plzarrense }\end{array}$} & \multicolumn{2}{|c|}{$\frac{\text { Lent I cul Ina }}{\mathrm{sp} \text {. }}$} & \multicolumn{2}{|c|}{$\begin{array}{l}\text { Lagena cf. } \\
\text { L.substriata }\end{array}$} \\
\hline & $\%$ & no. & $\%$ & no. & $\%$ & no. & $\%$ & no. & $\%$ & no. \\
\hline$A-1$ & 0.0 & 0 & 0.0 & 0 & 0.0 & 0 & 0.0 & 0 & 0.0 & 0 \\
\hline$A-2$ & 0.0 & 0 & 0.0 & 0 & 0.0 & 0 & 0.0 & 0 & 0.0 & 0 \\
\hline$A-3$ & 0.0 & 0 & 0.0 & 0 & 0.0 & 0 & 0.0 & 0 & 0.0 & 0 \\
\hline$A-4$ & 0.0 & 0 & 0.0 & 0 & 0.0 & 0 & 0.0 & 0 & 0.0 & 0 \\
\hline$A-5$ & 0.0 & 0 & 0.0 & 0 & 0.0 & 0 & 0.0 & 0 & 0.0 & 0 \\
\hline $8-1$ & 0.0 & 0 & 0.0 & 0 & 0.0 & 0 & 0.0 & 0 & 0.0 & 0 \\
\hline$B-2$ & 0.0 & 0 & 0.0 & 0 & 0.0 & 0 & 0.0 & 0 & 0.0 & 0 \\
\hline$B-3$ & 0.0 & 0 & 0.0 & 0 & 0.0 & 0 & 0.0 & 0 & 0.0 & 0 \\
\hline$B-4$ & 0.0 & 0 & 0.0 & 0 & 0.0 & 0 & 0.0 & 0 & 0.0 & 0 \\
\hline$B-5$ & 0.0 & 0 & 0.0 & 0 & 0.0 & 0 & 0.0 & 0 & 0.0 & 0 \\
\hline$C-1$ & 0.0 & 0 & 0.0 & 0 & 0.0 & 0 & 0.0 & 0 & 0.0 & 0 \\
\hline$C-2$ & 0.0 & 0 & 0.0 & 0 & 0.0 & 0 & 0.0 & 0 & 0.0 & 0 \\
\hline$C-3$ & 0.0 & 0 & 0.0 & 0 & 0.0 & 0 & 0.0 & 0 & 0.0 & 0 \\
\hline$c-4$ & 0.0 & 0 & 0.0 & 0 & 0.0 & 0 & 0.0 & 0 & 0.0 & 0 \\
\hline$C-5$ & 0.0 & 0 & 0.0 & 0 & 0.0 & 0 & 0.0 & 0 & 0.0 & 0 \\
\hline$D-1$ & 0.0 & 0 & 0.0 & 0 & 0.0 & 0 & 0.0 & 0 & 0.0 & 0 \\
\hline$D-2$ & 0.0 & 0 & 0.3 & 1 & 0.0 & 0 & 0.0 & 0 & 0.0 & 0 \\
\hline$D-3$ & 0.0 & 0 & 0.0 & 0 & 0.3 & 1 & 0.0 & 0 & 0.0 & 0 \\
\hline$D-4$ & 0.0 & 0 & 0.0 & 0 & 0.0 & 0 & 0.0 & 0 & 0.0 & 0 \\
\hline$D-5$ & 0.0 & 0 & 0.0 & 0 & 0.0 & 0 & 0.2 & 2 & 0.0 & 0 \\
\hline$E-1$ & 0.0 & 0 & 0.0 & 0 & 0.0 & 0 & 0.0 & 0 & 0.3 & 1 \\
\hline$E-2$ & 0.0 & 0 & 0.0 & 0 & 0.0 & 0 & 0.0 & 0 & 0.0 & 0 \\
\hline$E-3$ & 0.0 & 0 & 0.0 & 0 & 0.0 & 0 & 0.0 & 0 & 0.0 & 0 \\
\hline$E-4$ & 0.0 & 0 & 0.0 & 0 & 0.0 & 0 & 0.0 & 0 & 0.0 & 0 \\
\hline$E-5$ & 0.0 & 0 & 0.0 & 0 & 0.0 & 0 & 0.0 & 0 & 0.0 & 0 \\
\hline$F-1$ & 0.0 & 0 & 0.0 & 0 & 0.0 & 0 & 0.0 & 0 & 0.0 & 0 \\
\hline$F-2$ & 0.0 & 0 & 0.0 & 0 & 0.0 & 0 & 0.0 & 0 & 0.0 & 0 \\
\hline$F-3$ & 0.0 & 0 & 0.2 & 2 & 0.0 & 0 & 0.0 & 0 & 0.0 & 0 \\
\hline$F-4$ & 0.0 & 0 & 0.0 & 0 & 0.0 & 0 & 0.0 & 0 & 0.0 & 0 \\
\hline$F-5$ & 0.0 & 0 & 0.0 & 0 & 0.0 & 0 & 0.0 & 0 & 0.0 & 0 \\
\hline$G-1$ & 0.0 & 0 & 0.0 & 0 & 0.0 & 0 & 0.0 & 0 & 0.0 & 0 \\
\hline$G-2$ & 0.0 & 0 & 0.0 & 0 & 0.0 & 0 & 0.0 & 0 & 0.0 & 0 \\
\hline$G-3$ & 0.0 & 0 & 0.0 & 0 & 0.0 & 0 & 0.0 & 0 & 0.0 & 0 \\
\hline$G-4$ & 0.2 & 2 & 0.0 & 0 & 0.0 & 0 & 0.0 & 0 & 0.0 & 0 \\
\hline G-5 & 0.0 & 0 & 0.0 & 0 & 0.0 & 0 & 0.2 & 2 & 0.0 & 0 \\
\hline $\mathrm{H}-1$ & 0.0 & 0 & 0.0 & 0 & 0.0 & 0 & 0.3 & 1 & 0.0 & 0 \\
\hline $\mathrm{H}-2$ & 0.0 & 0 & 0.0 & 0 & 0.0 & 0 & 0.0 & 0 & 0.0 & 0 \\
\hline $\mathrm{H}-3$ & 0.0 & 0 & 0.0 & 0 & 0.0 & 0 & 0.0 & 0 & 0.0 & 0 \\
\hline $\mathrm{H}-4$ & 0.0 & 0 & 0.0 & 0 & 0.0 & 0 & 0.0 & 0 & 0.0 & 0 \\
\hline $\mathrm{H}-5$ & 0.0 & 0 & 0.0 & 0 & 0.0 & 0 & 0.0 & 0 & 0.0 & 0 \\
\hline $1-1$ & 0.0 & 0 & 0.0 & 0 & 0.0 & 0 & 0.0 & 0 & 0.0 & 0 \\
\hline $1-2$ & 0.0 & 0 & 0.0 & 0 & 0.0 & 0 & 0.0 & 0 & 0.0 & 0 \\
\hline $1-3$ & 0.0 & 0 & 0.0 & 0 & 0.0 & 0 & 0.0 & 0 & 0.0 & 0 \\
\hline $1-4$ & 0.0 & 0 & 0.0 & 0 & 0.0 & 0 & 0.0 & 0 & 0.0 & 0 \\
\hline $1-5$ & 0.0 & 0 & 0.0 & 0 & 0.0 & 0 & 0.0 & 0 & 0.0 & 0 \\
\hline
\end{tabular}


Appendix 1.-Continued.

\begin{tabular}{|c|c|c|c|c|c|c|c|}
\hline \multirow[t]{2}{*}{ Samp I $\theta$} & \multirow{2}{*}{$\begin{array}{l}\text { Total no. } \\
\text { specimens }\end{array}$} & \multirow[t]{2}{*}{ Splat slze } & \multirow[t]{2}{*}{ specles } & \multirow[t]{2}{*}{$H(S)$} & \multirow[t]{2}{*}{$E$} & \multicolumn{2}{|c|}{ Plankton I cs } \\
\hline & & & & & & & no. \\
\hline$A-1$ & 636 & $1 / 2$ & 13 & 1.54 & .36 & 0.6 & 4 \\
\hline$A-2$ & 611 & ALL & 18 & 1.64 & .29 & 0.2 & 1 \\
\hline$A-3$ & 1318 & $1 / 2$ & 16 & 1.29 & .23 & 0.2 & 2 \\
\hline$A-4$ & 804 & $1 / 2$ & 12 & 1.36 & .32 & 1.0 & 8 \\
\hline$A-5$ & 994 & $1 / 2$ & 15 & 1.56 & .32 & 0.0 & 0 \\
\hline$B-1$ & 1096 & $1 / 2$ & 15 & 1.31 & .25 & 0.2 & 2 \\
\hline$B-2$ & 421 & ALL & 17 & 1.70 & .32 & 0.2 & 1 \\
\hline$B-3$ & 315 & ALL & 14 & 1.82 & .44 & 0.0 & 0 \\
\hline$B-4$ & 652 & $1 / 2$ & 13 & 1.64 & .40 & 2.1 & 14 \\
\hline$B-5$ & 758 & $1 / 2$ & 12 & 1.37 & .33 & 0.0 & 0 \\
\hline$C-1$ & 1342 & $1 / 2$ & 19 & 1.43 & .22 & 0.0 & 0 \\
\hline$c-2$ & 1103 & ALL & 21 & 1.44 & .20 & 0.4 & 5 \\
\hline$C-3$ & 640 & $1 / 2$ & 16 & 1.61 & .31 & 0.6 & 4 \\
\hline$C-4$ & 842 & $1 / 2$ & 16 & 1.42 & .26 & 0.5 & 4 \\
\hline$C-5$ & 545 & ALL & 14 & 1.64 & .37 & 0.0 & 0 \\
\hline$D-1$ & 138 & ALL & 14 & 1.85 & .45 & 0.7 & 1 \\
\hline$D-2$ & 355 & ALL & 15 & 1.65 & .35 & 0.0 & 0 \\
\hline$D-3$ & 348 & ALL & 13 & 1.29 & .28 & 0.0 & 0 \\
\hline$D-4$ & 590 & $1 / 2$ & 14 & 1.76 & .42 & 0.0 & 0 \\
\hline$D-5$ & 846 & $1 / 2$ & 17 & 1.65 & .31 & 0.5 & 4 \\
\hline$E-1$ & 452 & $3 / 4$ & 18 & 1.85 & .35 & 0.6 & 3 \\
\hline$E-2$ & 475 & $3 / 4$ & 13 & 1.56 & .36 & 0.6 & 3 \\
\hline$E-3$ & 1254 & $1 / 2$ & 15 & 1.43 & .28 & 0.0 & 0 \\
\hline$E-4$ & 940 & $1 / 2$ & 15 & 1.50 & .30 & 0.4 & 2 \\
\hline$E-5$ & 994 & $1 / 2$ & 16 & 1.52 & .29 & 0.0 & 0 \\
\hline$F-1$ & 1540 & $1 / 2$ & 17 & 1.33 & .22 & 0.1 & 2 \\
\hline$F-2$ & 1124 & $1 / 2$ & 15 & 1.50 & .30 & 0.0 & 0 \\
\hline$F-3$ & 932 & $1 / 2$ & 17 & 1.49 & .26 & 0.6 & 6 \\
\hline$F-4$ & 1358 & $1 / 2$ & 15 & 1.46 & .29 & 0.3 & 4 \\
\hline$F-5$ & 646 & $3 / 4$ & 16 & 1.53 & .29 & 0.2 & 1 \\
\hline$G-1$ & 600 & $3 / 4$ & 17 & 1.60 & .29 & 0.2 & 1 \\
\hline$G-2$ & 318 & ALL & 15 & 1.73 & .38 & 0.0 & 0 \\
\hline G-3 & 237 & ALL & 13 & 1.81 & .47 & 0.0 & 0 \\
\hline$G-4$ & 824 & $1 / 2$ & 15 & 1.57 & .32 & 0.2 & 2 \\
\hline G-5 & 896 & $1 / 2$ & 15 & 1.51 & .30 & 0.2 & 2 \\
\hline $\mathrm{H}-1$ & 313 & ALL & 15 & 1.88 & .44 & 0.0 & 0 \\
\hline $\mathrm{H}-2$ & 1330 & $1 / 2$ & 16 & 1.30 & .23 & 0.0 & 0 \\
\hline $\mathrm{H}-3$ & 1080 & $1 / 2$ & 15 & 1.52 & .30 & 0.4 & 4 \\
\hline $\mathrm{H}-4$ & 876 & $1 / 2$ & 17 & 1.52 & .27 & 0.0 & 0 \\
\hline $\mathrm{H}-5$ & 377 & ALL & 14 & 1.66 & .38 & 0.0 & 0 \\
\hline $\mid-1$ & 830 & $1 / 2$ & 19 & 1.41 & .22 & 0.7 & 6 \\
\hline $1-2$ & 1260 & $1 / 2$ & 16 & 1.42 & .26 & 0.3 & 4 \\
\hline $1-3$ & 261 & ALL & 15 & 1.95 & .47 & 0.0 & 0 \\
\hline $1-4$ & 724 & $1 / 2$ & 12 & 1.47 & .36 & 0.0 & 0 \\
\hline $1-5$ & 460 & $3 / 4$ & 15 & 1.69 & .36 & 0.2 & 3 \\
\hline
\end{tabular}




\section{Literature Cited}

Andrews, G.W.

1976. Miocene Marine Diatoms from the Choptank Formation, Calvert County, Maryland. US. Geological Survey Professional Paper, 910: 26 pages.

1988. A Revised Marine Diatom Zonation for Miocene Strata of the Southeastern United States. U.S. Geological Survey Professional Paper, 1481: 29 pages.

Berggren, W.A., D.V. Kent, and J.A. van Couvering

1985. The Neogene, Part 2: Neogene Geochronology and Chronostratigraphy. In N.J Snelling, editor, The Chronology of the Geological Blow, W.H. Record. The Geological Society of America, Memoir, 90:211-260.

1969. Late Middle Eocene to Recent Planktonic Foraminiferal Biostratigraphy. In P. Bronnimann and H.H. Renz, editors, Proceedings of the First International Conference on Plankonic Microfossils, Geneva, 1967, 1:199-422.

Boltovskoy, E., and H. Lena

1969. Seasonal Occurrences, Standing Crop and Production in Benthic Foraminifera of Puerto Deseado. Contributions from the Cushman Foundation for Foraminiferal Research, 20: 87-95.

Buzas, M.A.

1965. The Distribution and Abundance of Foraminifera in Long Island Sound. Smithsonian Miscellaneous Collections, 149(1): 89 pages.

1966. The Discrimination of Morphological Groups of Elphidium (Foraminifer) in Long Island Sound through Canonical Analysis and Invarient Characters. Jowrnal of Paleontology, 40:585-594.

1967. An Application of Canonical Analysis as a Method of Comparing Faunal Areas. Journal of Animal Ecology, 36:563-577.

1968. On the Spatial Distribution of Foraminifera. Contributions from the Cushman Foundation for Foraminiferal Research, 19:1-11.

1970. Spatial Homogeneity: Statistical Analyses of Unispecies and Multispecies Populations of Foraminifera. Ecology, 51:874-879.

Buzas, M.A., R.K. Smith, and K.A. Beem

1977. Ecology and Systematics of Foraminifera in Two Thalassia Habitats, Jamaica, West Indies. Smithsonian Contributions to Gemant, R.E. Paleobiology, 31: 139 pages.

1970. Paleoecology of the Choptank Formation (Miocene) of Maryland and Virginia. Maryland Geological Survey Report of Investigations,

Gibson, T.G. 12: 90 pages.

1962. Benthonic Foraminifera and Paleoecology of the Miocene Deposits of the Middle Atlantic Coastal Plain. 198 pages. Doctoral dissertation, Princeton University.

1983. Stratigraphy of Miocene through Lower Pleistocene Strata of the United States Central Atlantic Coastal Plain. In C.E. Ray, editor, Geology and Paleontology of the Lee Creek Mine, North Carolina, I. Smithsonian Contributions to Paleobiology, 53:35-80.

Gibson, T.G., and M.A. Buzas

1973. Species Diversity: Patterns in Modern and Miocene Foraminifera of the Eastern Margin of North America. Geological Society of America Bulletin, 84:217-238.

Greig-Smith, P.

1964. Quantitative Plant Ecology. 256 pages. London: Butterworthes.

Kidwell, S.M.

1984. Outcrop Features and Origin of Basin Margin Unconformities in the Lower Chesapeake Group (Miocene), Atlantic Coastal Plain. American Association of Petrolewm Geologists Memoir, 36:37-58.

Lutze, G.F.

1968. Jahregang der Foraminiferen-Fauna in der Bottsnad-Lagune (westliche Ostsee). Meyniana, 18:14-30.

Lynts, G.W.

1966. Variation of Foraminiferal Standing Crop Over Short Lateral Distances in Buttonwood Sound, Florida. Limnology and Oceanography, 11:562-566.

Olsson, I., and B. Eriksson

1974. Horizontal Distribution of Meiofauna within a Small Area, with Special Reference to Foraminifera. Zoon, 2:67-84.

Reyment, R.A., R.E. Blackith, and N.A. Cambell

1984. Multivariate Morphometrics. 233 pages. London: Academic Press. Schafer, C.T.

1968 Lateral and Temporal Variation of Foraminifera Populations Living in Nearshore Shallow Water Areas. 28 pages. Manuscript (number 68-4) on file at the Atlantic Oceanographic Laboratory, Bedford Institute, Dartmouth, Nova Scotia, Canada.

1971. Sampling and Spatial Distribution of Benthonic Foraminifera. Limnology and Oceanography, 16:944-951.

Schafer, C.T., and P.J. Mudie

1980. Spatial Variability of Foraminifera and Pollen in Two Nearshore Sediment Sites, St. Georges Bay, Nova Scotia. Canadian Jowrnal of Earth Sciences, 17:313-324.

Scoth, G.H.

1958. Distribution of Populations of Fossil Foraminifera. New Zealand Journal of Geology and Geophysics, 1:474-484.

Seal, $\mathrm{H}$.

1964. Multivariate Statistical Analysis for Biologists. 207 pages. London: Methuen and Co., Lid.

Shatuck, G.B.

1904. Geological and Paleontological Relations, with a Review of Earlier Investigations. In W.B. Clark, G.B. Shatuck, and W.H. Dall, editors, The Miocene Deposits of Maryland. Maryland Geological Swrvey, 2:xrxiii-cxxiii.

Shifflett, E.

1961. Living, Dead and Total Foraminiferal Faunas, Heald Bank, Gulf of Mexico. Micropaleontology, 7:45-54.

Smith, R.K., and M.A. Buzas

1986. Microdistribution of Foraminifera in a Single Bed of the Monterey Formation, Monterey County, California. Smithsonian Contributions to Paleobiology, 60: 33 pages. 



\section{REQUIREMENTS FOR SMITHSONIAN SERIES PUBLICATION}

Manuscripts intended for series publication receive substantive review (conducted by their originating Smithsonian museums or offices) and are submitted to the Smithsonian Institution Press with Form SI-36, which must show the approval of the appropriate authority designated by the sponsoring organizational unit. Requests for special treatment-use of color, foldouts, case-bound covers, etc.-require, on the same form, the added approval of the sponsoring authority.

Review of manuscripts and art by the Press for requirements of series format and style, completeness and clarity of copy, and arrangement of all material, as outlined below, will govern, within the judgment of the Press, acceptance or rejection of manuscripts and art.

Copy must be prepared on typewriter or word processor, double-spaced, on one side of standard white bond paper (not erasable), with 11/4" margins, submitted as ribbon copy (not carbon or xerox), in loose sheets (not stapled or bound), and accompanied by original art. Minimum acceptable length is 30 pages.

Front matter (preceding the text) should include: title page with only title and author and no other information, abstract page with author, title, series, etc., following the established format; table of contents with indents reflecting the hierarchy of heads in the paper; also, foreword and/or preface, if appropriate.

First page of text should carry the title and author at the top of the page; second page should have only the author's name and professional mailing address, to be used as an unnumbered footnote on the first page of printed text.

Center heads of whatever level should be typed with initial caps of major words, with extra space above and below the head, but no other preparation (such as all caps or underline, except for the underline necessary for generic and specific epithets). Run-in paragraph heads should use period/dashes or colons as necessary.

Tabulations within text (lists of data, often in parallel columns) can be typed on the text page where they occur, but they should not contain rules or numbered table captions.

Formal tables (numbered, with captions, boxheads, stubs, rules) should be submitted as carefully typed, double-spaced copy separate from the text; they will be typeset unless otherwise requested. If camera-copy use is anticipated, do not draw rules on manuscript copy.

Taxonomic keys in natural history papers should use the aligned-couplet form for zoology and may use the multi-level indent form for botany. If cross referencing is required between key and text, do not include page references within the key, but number the keyed-out taxa, using the same numbers with their corresponding heads in the text.

Synonymy in zoology must use the short form (taxon, author, year:page), with full reference at the end of the paper under "Literature Cited." For botany, the long form (taxon, author, abbreviated journal or book title, volume, page, year, with no reference in "Literature Cited") is optional.

Text-reference system (author, year:page used within the text, with full citation in "Literature Cited" at the end of the text) must be used in place of bibliographic footnotes in all Contributions Series and is strongly recommended in the Studies Series: "(Jones, 1910:122)" or ". . Jones (1910:122)." If bibliographic footnotes are required, use the short form (author, brief title, page) with the full citation in the bibliography.

Footnotes, when few in number, whether annotative or bibliographic, should be typed on separate sheets and inserted immediately after the text pages on which the references occur. Extensive notes must be gathered together and placed at the end of the text in a notes section.

Bibliography, depending upon use, is termed "Literature Cited," "References," or "Bibliography." Spell out titles of books, articles, journals, and monographic series. For book and article titles use sentence-style capitalization according to the rules of the language employed (exception: capitalize all major words in English). For journal and series titles, capitalize the initial word and all subsequent words except articles, conjunctions, and prepositions. Transliterate languages that use a non-Roman alphabet according to the Library of Congress system. Underline (for italics) titles of journals and series and titles of books that are not part of a series. Use the parentheses/colon system for volume (number): pagination: "10(2):5-9." For alignment and arrangement of elements, follow the format of recent publications in the series for which the manuscript is intended. Guidelines for preparing bibliography may be secured from Series Section, SI Press.

Legends for illustrations must be submitted at the end of the manuscript, with as many legends typed, double-spaced, to a page as convenient.

Illustrations must be submitted as original art (not copies) accompanying, but separate from, the manuscript. Guidelines for preparing art may be secured from Series Section, SI Press. All types of illustrations (photographs, line drawings, maps, etc.) may be intermixed throughout the printed text. They should be termed Figures and should be numbered consecutively as they will appear in the monograph. If several illustrations are treated as components of a single composite figure, they should be designated by lowercase italic letters on the illustration; also, in the legend and in text references the italic letters (underlined in copy) should be used: "Figure 9b." Illustrations that are intended to follow the printed text may be termed Plates, and any components should be similarly lettered and referenced: "Plate 9b." Keys to any symbols within an illustration should appear on the art rather than in the legend.

Some points of style: Do not use periods after such abbreviations as "mm, $\mathrm{ft}$, USNM, NNE." Spell out numbers "one" through "nine" in expository text, but use digits in all other cases if possible. Use of the metric system of measurement is preferable; where use of the English system is unavoidable, supply metric equivalents in parentheses. Use the decimal system for precise measurements and relationships, common fractions for approximations. Use day/month/year sequence for dates: "9 April 1976." For months in tabular listings or data sections, use three-letter abbreviations with no periods: "Jan, Mar, Jun," etc. Omit space between initials of a personal name: "J.B. Jones."

Arrange and paginate sequentially every sheet of manuscript in the following order: (1) title page, (2) abstract, (3) contents, (4) foreword and/or preface, (5) text, (6) appendixes, (7) notes section, (8) glossary, (9) bibliography, (10) legends, (11) tables. Index copy may be submitted at page proof stage, but plans for an index should be indicated when manuscript is submitted. 


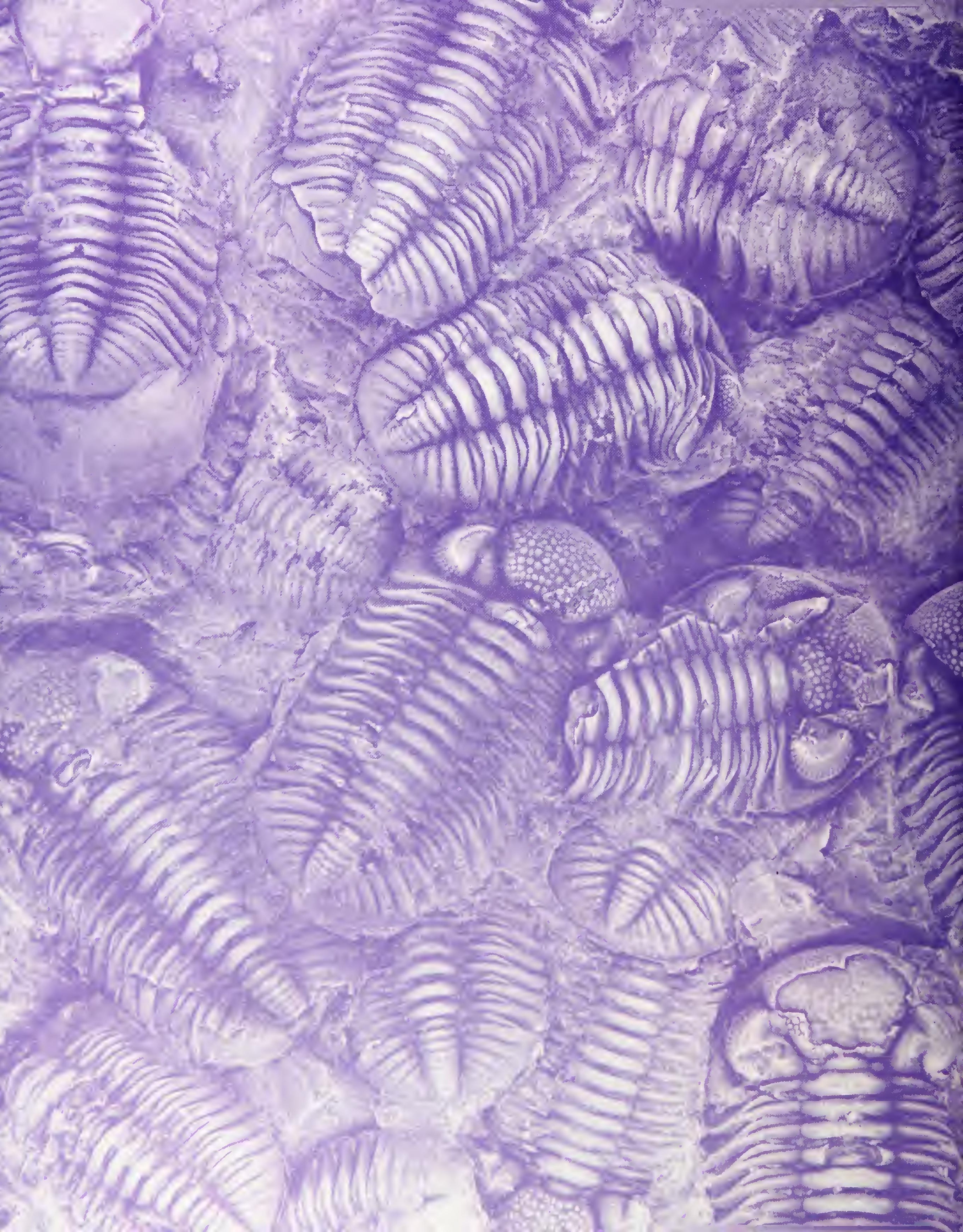

